\title{
Palynostratigraphy of the Tullock Member (lower Paleocene) of the Fort Union Formation in the Powder River Basin, Montana and Wyoming
}

\section{U.S. GEOLOGICAL SURVEY BULLETIN 1917-F}

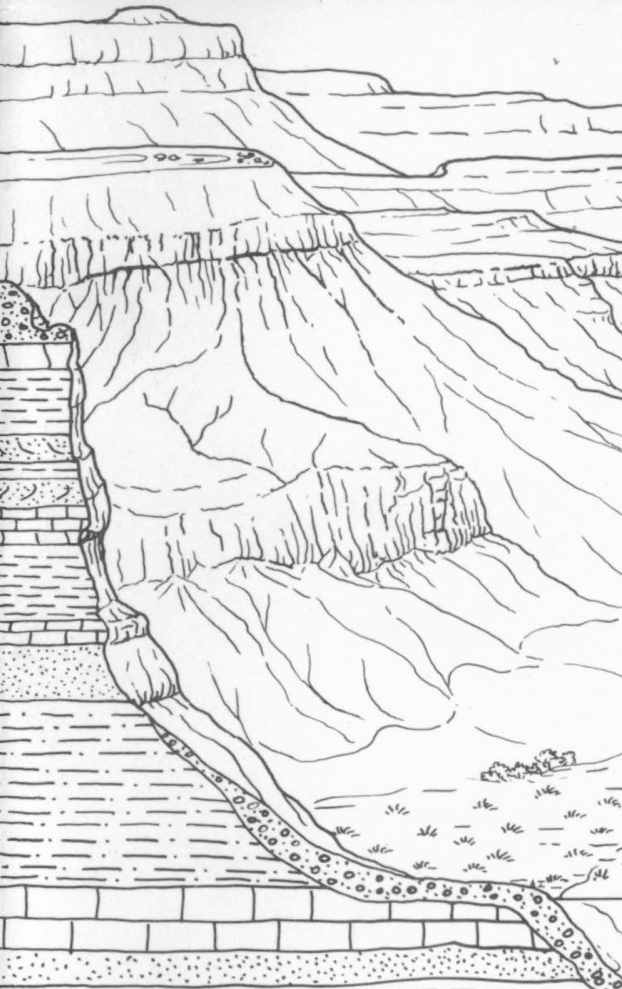

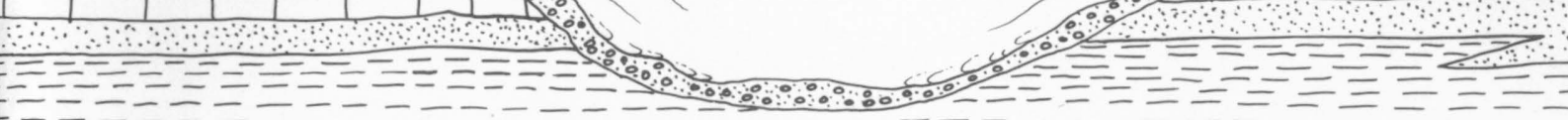

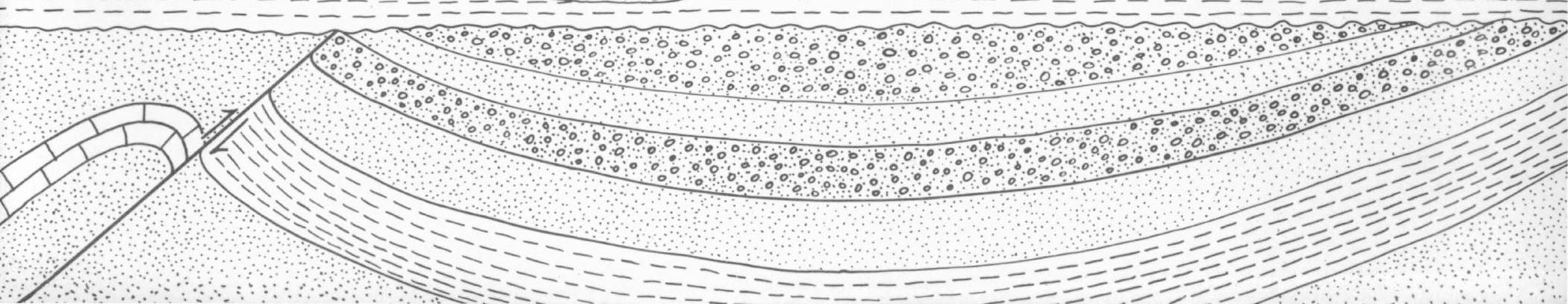




\section{AVAILABILITY OF BOOKS AND MAPS OF THE U.S. GEOLOGICAL SURVEY}

Instructions on ordering publications of the U.S. Geological Survey, along with the last offerings, are given in the current-year issues of the monthly catalog "New Publications of the U.S. Geological Survey." Prices of available U.S. Geological Survey publications released prior to the current year are listed in the most recent annual "Price and Availability List." Publications that are listed in various U.S. Geological Survey catalogs (see back inside cover) but not listed in the most recent annual "Price and Availability List" are no longer available.

Prices of reports released to the open files are given in the listing "U.S. Geological Survey Open-File Reports," updated monthly, which is for sale in microfiche from the U.S. Geological Survey Books and Open-File Reports Sales, Box 25425, Denver, CO 80225.

Order U.S. Geological Survey publications by mail or over the counter from the offices given below.

\section{BY MAIL}

\section{Books}

Professional Papers, Bulletins, Water-Supply Papers, Techniques of Water-Resources Investigations, Circulars, publications of general interest (such as leaflets, pamphlets, booklets), single copies of periodicals (Earthquakes \& Volcanoes, Preliminary Determination of Epicenters), and some miscellaneous reports, including some of the foregoing series that have gone out of print at the Superintendent of Documents, are obtainable by mail from

\section{U.S. Geological Survey, Books and Open-File Report Sales Box 25425 Denver, CO 80225}

Subscriptions to periodicals (Earthquakes \& Volcanoes and Preliminary Determination of Epicenters) can be obtained ONLY from

\section{Superintendent of Documents \\ U.S. Government Printing Office Washington, DC 20402} Documents.)

(Check or money order must be payable to Superintendent of Maps

For maps, address mail order to

\section{U.S. Geological Survey, Map Sales Box 25286 Denver, CO 80225}

Residents of Alaska may order maps from

\author{
U.S. Geological Survey, Map Sales \\ 101 Twelfth Ave., Box 12 \\ Fairbanks, AK 99701
}

\section{OVER THE COUNTER}

\section{Books}

Books of the U.S. Geological Survey are available over the counter at the following U.S. Geological Survey offices, all of which are authorized agents of the Superintendent of Documents.

- ANCHORAGE, Alaska-4230 University Dr., Rm. 101

- ANCHORAGE, Alaska-605 West 4th Ave., Rm G-84

- DENVER, Colorado-Federal Bldg., Rm. 169, 1961 Stout St.

- LAKEWOOD, Colorado-Federal Center, BIdg. 810

- MENLO PARK, California-Bldg. 3, Rm. 3128, 345 Middlefield Rd.

- RESTON, Virginia-National Center, Rm. 1C402, 12201 Sunrise Valley Dr.

- SALT LAKE CITY, Utah-Federal Bldg., Rm. 8105, 125 South State St.

- SAN FRANCISCO, California-Customhouse, Rm. 504, 555 Battery St.

- SPOKANE, Washington-U.S. Courthouse, Rm. 678, West 920 Riverside Ave.

- WASHINGTON, D.C.-U.S. Department of the Interior Bldg., Rm. 2650, 1849 C St., NW.

\section{Maps}

Maps may be purchased over the counter at the U.S. Geological Survey offices where books are sold (all addresses in above list) and at the following Geological Survey offices:

- ROLLA, Missouri-1400 Independence Rd.

- FAIRBANKS, Alaska-New Federal Building, 101 Twelfth Ave. 
Chapter $\mathrm{F}$

Palynostratigraphy of the

Tullock Member (lower Paleocene) of the Fort Union Formation in the

Powder River Basin, Montana and Wyoming

BY DOUGLAS J. NICHOLS and JANET L. BROWN

A multidisciplinary approach to research studies of sedimentary rocks and their constituents and the evolution of sedimentary

basins, both ancient and modern

U.S. GEOLOGICAL SURVEY BULLETIN 1917

EVOLUTION OF SEDIMENTARY BASINS-POWDER RIVER BASIN 


\section{U.S. DEPARTMENT OF THE INTERIOR}

MANUEL LUJAN, JR., Secretary

U.S. GEOLOGICAL SURVEY

Dallas L. Peck, Director

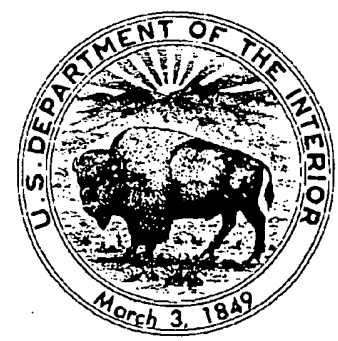

Any use of trade, product, or firm names in this publication is for descriptive purposes only and does not imply endorsement by the U.S. Government

UNITED STATES GOVERNMENT PRINTING OFFICE: 1992

For sale by the

Books and Open-File Reports Section

U.S. Geological Survey

Federal Center

Box 25425

Denver, CO 80225

\section{Library of Congress Cataloging-in-Publication Data}

Nichols,. Douglas J.

Palynostratigraphy of the Tullock Member (lower Paleocene) of the Fort Union

Formation in the Powder River Basin, Montana and Wyoming / by Douglas J.

Nichols and Janet L. Brown.

p. $\quad \mathrm{cm}$. - (Evolution of sedimentary basins_Powder River Basin ; ch. F)

(U.S. Geological Survey bulletin ; 1917-F)

"A multidisciplinary approach to research studies of sedimentary rocks and their constituents and the evolution of sedimentary basins, both ancient and modern."

Includes bibliographical references.

Supt. of Docs. no.: I 19.3: 1917F

1. Geology, Stratigraphic-Paleocene. 2. Palynology-Rocky Mountains

Region. 3. Palynology-Powder River Basin (Wyo. and Mont.)

4. Geology-Rocky Mountains Region. 5. Geology-Powder River Basin (Wyo. and Mont.) 6. Fort Union Formation. I. Brown, Janet L. II. Title. III. Series. IV. Series: U.S. Geological Survey bulletin ; 1917-F.

QE75.B9 no. 1917-F

[QE692]

$557.3 \mathrm{~s}-\mathrm{dc} 20$

[551.7'83] 


\section{CONTENTS}

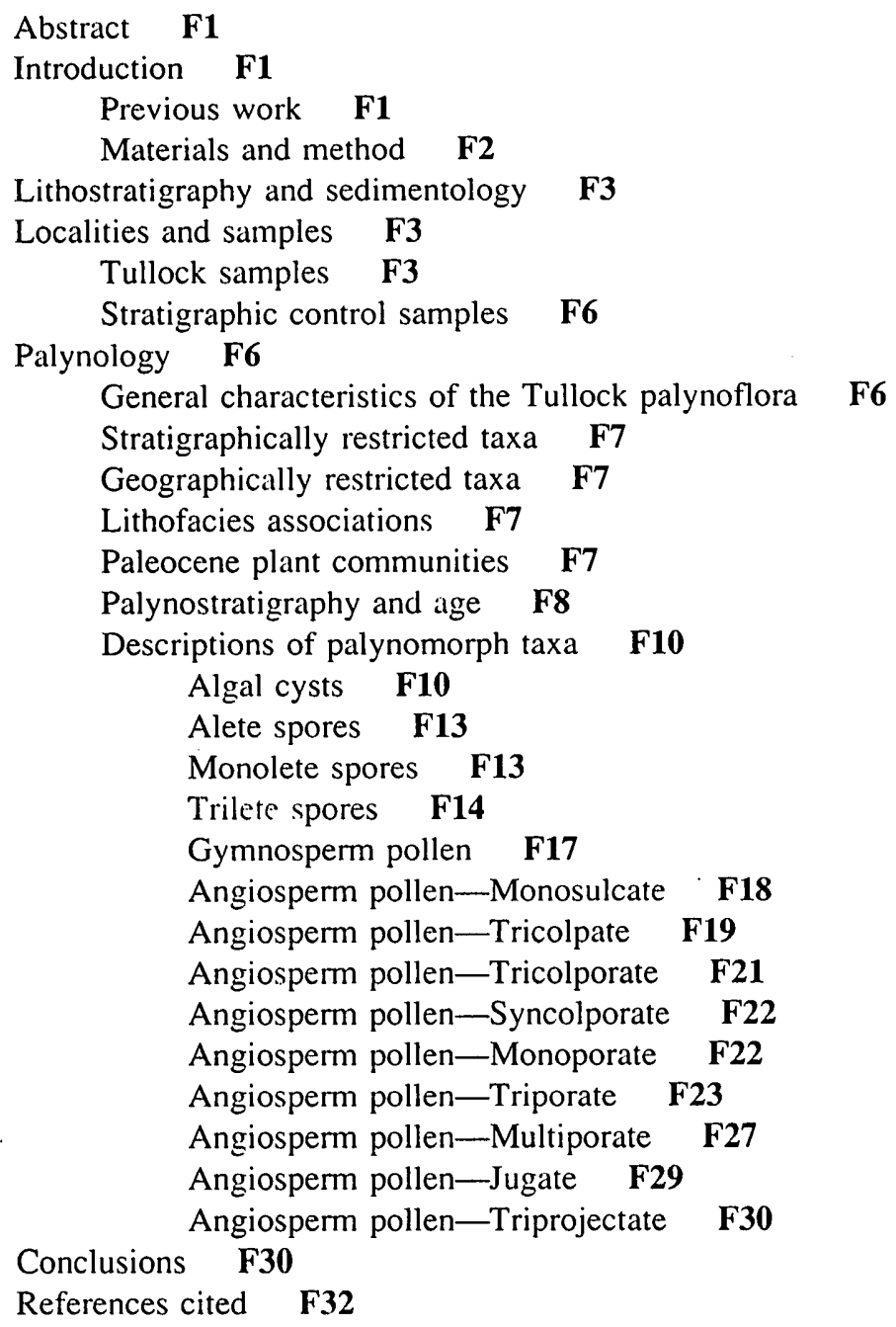

\section{PLATES}

[Plates follow text]

1. Algal cysts and monolete spores.

2. Monolete and trilete spores.

3, 4. Trilete spores.

5. Gymnosperm pollen.

6. Gymnosperm pollen and monosulcate and tricolpate angiosperm pollen.

7. Tricolpate and tricolporate angiosperm pollen.

8. Tricolporate, syncolporate, monoporate, and triporate angiosperm pollen.

9. Triporate, multiporate, and dyad angiosperm pollen.

10. Jugate, triprojectate, and multiporate (oculate) angiosperm pollen. 
FIGURES

1. Generalized map showing Powder River Basin in Montana and Wyoming

2. Chart showing stratigraphic nomenclature for uppermost Cretaceous and lowermost Tertiary rocks in Powder River Basin

F2

3-4. Maps showing sample localities in the Tullock Member:

3. Northern Powder River Basin, Montana F4

4. Southern Powder River Basin, Wyoming F5

5. Diagram showing relationship between Cretaceous-Tertiary boundary and formation contacts at three sections in Powder River Basin F31

6. Map showing paleogeography of area of Powder River Basin in earliest Paleocene time $\quad \mathbf{F 3 2}$

TABLE

1. Alphabetical list of palynomorph taxa from the Tullock Member discussed in this report, with full nomenclatural citations

F10 


\title{
Palynostratigraphy of the Tullock Member (lower Paleocene) of the Fort Union Formation in the Powder River Basin, Montana and Wyoming
}

\author{
By Douglas J. Nichols and Janet L. Brown
}

\begin{abstract}
The palynostratigraphy of the Tullock Member of the Fort Union Formation in the Powder River Basin, southeastern Montana and northeastern Wyoming, was investigated in support of basin analysis research and as a contribution to Tertiary palynology of the Rocky Mountain region. Thirty samples collected from coal, carbonaceous shale, shale, and mudstone at 11 localities were analyzed in detail. Most of these samples represent the lower part of the Tullock Member; samples from the middle and upper parts of the Tullock also were analyzed, and stratigraphic control was provided by samples from the overlying Lebo Member of the Fort Union and the underlying Lance and Hell Creek Formations.

The Tullock Member is early Paleocene in age. Tullock palynomorph assemblages include species characteristic of lower Paleocene palynostratigraphic zones $\mathrm{P} 1$ and $\mathrm{P} 2$ and show resemblance to contemporaneous assemblages elsewhere in Montana and Wyoming and in North and South Dakota, Colorado, New Mexico, and Alberta, Canada. Basal Paleocene zone P1 in the Powder River Basin is characterized by presence of the pollen species Momipites inaequalis and $M$. tenuipolus and (in Montana) Wodehouseia fimbriata. The overlying zone $\mathrm{P} 2$ in the Powder River Basin includes $M$. inaequalis and $M$. tenuipolus, as well as other species of Momipites that characterize this biozone elsewhere. The most commonly occurring palynomorphs in the Tullock palynoflora are the fern spores Cyathidites diaphana and Laevigatosporites spp., conifer pollen assigned to Pityosporites spp., and the angiosperm pollen taxa Arecipites tenuiexinous, Tricolpites spp., and Ulmipollenites krempii. These species and the bryophyte spores Stereisporites spp., fern spores Reticuloidosporites pseudomurii, Toroisporis major, and Gleicheniidites
\end{abstract}

Manuscript approved for publication January 31, 1991. sp., and angiosperm pollen species Pandaniidites typicus, Kurtzipites spp., and Triporopollenites spp. are numerically abundant in some samples.

In the taxonomic discussions, 67 taxa are treated, of which 41 are pollen of angiosperms, 6 are pollen of gymnosperms, 12 are spores of bryophytes or pteridophytes (principally ferns), and 8 are cysts of algae (principally chlorophytes). Two species are redescribed on the basis of Tullock specimens, and 5 new nomenclatural combinations are proposed.

\section{INTRODUCTION}

This study was undertaken in support of a basin analysis study (Brown, in press) of the Tullock Member of the Fort Union Formation in the Powder River Basin. The objective of the palynological research was to provide biostratigraphic control for determination of timing of Tullock depositional events and to contribute to an understanding of Tullock depositional environments. In addition, there were two independent objectives: to describe the palynoflora of the Tullock Member as a contribution to Tertiary palynology of the Rocky Mountain region and to refine the palynostratigraphy of the lower Paleocene, in the Powder River Basin in particular and in the Rocky Mountain region in general. Figure 1 is a generalized map of the study area; figure 2 shows the stratigraphic nomenclature for the study interval.

\section{Previous Work}

The most important previously published work on the palynology of the Tullock Member is that of Leffingwell 


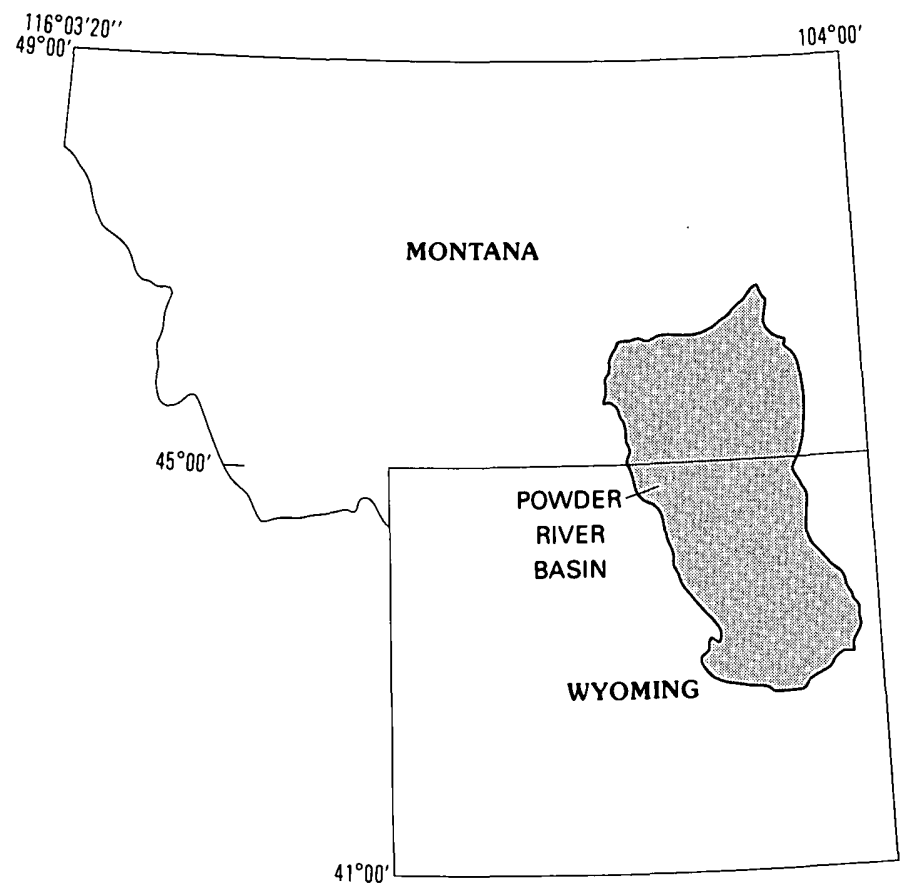

Figure 1. Location of the Powder River Basin in Montana and Wyoming. Outline of the basin drawn at the base of the Fox Hills Sandstone (Upper Cretaceous). Modified from Lewis and Hotchkiss (1981).

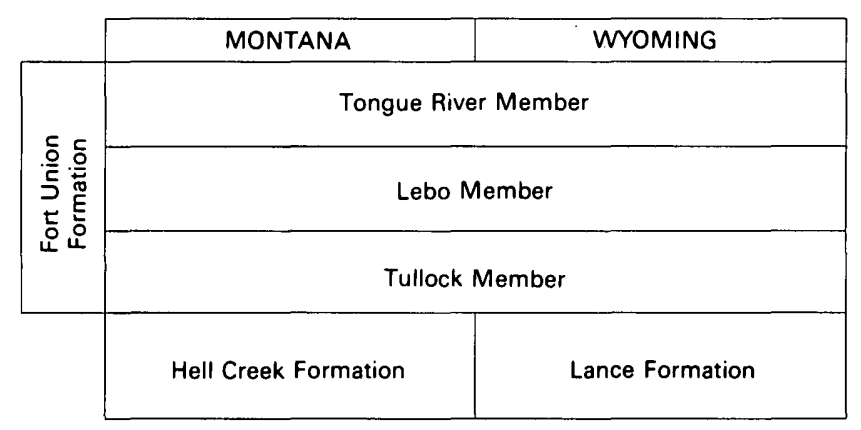

Figure 2. Stratigraphic nomenclature for uppermost Cretaceous and lowermost Tertiary rocks in the Powder River Basin.

(1970), who studied the Tullock and overlying Lebo and Tongue River Members of the Fort Union Formation, as well as the underlying Lance Formation (Upper Cretaceous). Leffingwell's study areas were the type area of the Lance Formation and the Gillette coal field, both of which are in the southeastern part of the Powder River Basin, and the Spotted Horse coal field in the central part of the basin, just south of the Montana-Wyoming State line. Leffingwell documented the occurrences of 35 spore and pollen taxa in his Assemblage B, which includes the Tullock Member and lower part of the Lebo Member. He also closely bracketed the position of the Cretaceous-Tertiary $(\mathrm{K}-\mathrm{T})$ boundary in the type Lance area on the basis of palynostratigraphy and found it to be well below the top of the Lance Formation. In addition to his palynostratigraphic results, Leffingwell conducted a careful taxonomic investigation of Lance and Fort Union palynomorphs, including the description of several new species, which provided a sound basis for later studies, including the present one.

Prior to Leffingwell's work, the palynology of the lower Paleocene in Montana, Wyoming, and adjacent areas had been the subject of studies by Stanley (1965), who described palynomorphs from the Ludlow Member of the Fort Union in northwestern South Dakota, and Norton and Hall (1969), who described palynomorphs from the Tullock in the Hell Creek area, Montana. Although Stanley's work suffers somewhat from now being some 25 years out of date and consequently in need of revision, both of these reports proved useful in the present study.

Nichols and Ott (1978) described some new species of pollen from the Fort Union in the Wind River basin, Wyoming, and proposed a palynostratigraphic zonation of the Paleocene. Their lower Paleocene zones $\mathrm{P} 1$ and $\mathrm{P} 2$ are relevant to the Tullock Member, but the present study reveals some interbasinal variations in lower Paleocene palynofloras. Recent work by Demchuk (1990) in Alberta and by Fleming (1990) in New Mexico documents other regional variations in lower Paleocene palynostratigraphy.

Other recent work specifically on the Tullock Member includes that of Bohor and others (1987), who precisely located the $\mathrm{K}-\mathrm{T}$ boundary in the type Lance area on the basis of palynostratigraphy, trace-element geochemistry, and the presence of shock-metamorphosed minerals. Nichols and others (in press) described in detail another K-T boundary locality in the western part of the basin. That locality was discovered in the course of the present study, and some samples from that locality are discussed in this report.

\section{Materials and Methods}

More than 100 samples for palynologic analysis were collected from the Tullock Member at 14 outcrop localities in the Powder River Basin in the course of this study. Among these, 30 samples from 11 localities were selected for detailed analysis and discussion in this report. In addition to the samples from the Tullock Member, about 50 samples were collected from the underlying Hell Creek and Lance Formations and a few from the overlying Lebo Member of the Fort Union Formation. Selected samples from this suite were studied to provide biostratigraphic (palynostratigraphic) control. Some of the palynomorphs recovered from these control samples are discussed here, but none are described or illustrated. All samples were processed following standard techniques for Tertiary coal and clastic sedimentary rocks as described by Doher (1980). 
LITHOSTRATIGRAPHY AND SEDIMENTOLOGY

Detailed descriptions and interpretations of the lithostratigraphy and sedimentology of the Tullock Member have been prepared by Brown (in press); major aspects of the unit are summarized here. The Tullock Member is the basal unit of the Paleocene Fort Union Formation in the Powder River Basin. It consists of fine-grained sandstone, sandy siltstone, mudstone, shale, rare thin limestone, and coal. In the field the Tullock is distinguished from the underlying Hell Creek Formation (in Montana) or Lance Formation (in Wyoming) by a sometimes subtle change in color from drab or gray-green beds (Hell Creek and Lance) to yellow or buff beds that contain coal (Tullock). The base of the Tullock is placed at the base of the first coal bed or coal zone above the Hell Creek or Lance. The contact of the Tullock with the overlying Lebo Member of the Fort Union Formation tends to be gradational but is marked by a change from buff sandstone and shale to generally drab (dark gray to olive gray) shale. The Tullock Member ranges in thickness from $113 \mathrm{~m}$ in the northwestern part of the basin to $439 \mathrm{~m}$ in the southeast (Brown, in press).

The geometry of Tullock sandstone bodies as determined from integration of subsurface and outcrop data (Brown, unpublished data) indicates a dominantly finegrained fluvial system consisting of small isolated stream courses incised into mudstones of floodplain origin. Floodplain sediments comprise more than 70 percent of the Tullock Member. The vertical succession of sedimentary structures is typical of fining-upward sequences that characterize fluvial systems. Isolated channel-form sandstones, as wide as $300 \mathrm{~m}$, contain rare lateral accretion deposits and are indicative of low-sinuosity channels that had limited sweep or migration over the floodplain. Paleocurrent directions determined from measurements on trough cross-sets show that stream flowed to the east and northeast. A lack of alluvial ridges in channels indicates little difference between elevation of river beds and the floodplain surface. Lack of prominent alluvial ridges is due to the dominance of clay, silt, and fine sand in overbank deposits and the presence of bank vegetation that prevented coarsegrained bedload sediment from washing onto the floodplain surface. Successive sediment pulses were responsible for zones of convolute bedding and destruction of some primary structures by liquefaction.

In total, these features suggest a small-scale fluvial system that traversed a stable floodplain of low relief in which small lakes were present and peat-forming mire environments were common. Palynomorphs produced by the local and regional vegetation tended to be deposited in fine-grained facies, including mudstone, shale, carbonaceous shale, and coal. Where those facies were not subjected to penecontemporaneous or postdepositional oxidation, palynomorphs were preserved.
It has been common practice among field geologists working in the Powder River Basin and elsewhere in the Rocky Mountain region to equate the Cretaceous-Tertiary (K-T) boundary with the contact between the Tullock Member and the underlying formations. Brown (1962) extensively reviewed the history of this practice and concluded that the "formula" (attributed to Calvert, 1912) for locating the K-T boundary at the first persistent coal zone above the stratigraphically highest dinosaur is valid. This approximation may serve as a mapping criterion, but the lithostratigraphic contact and the chronostratigraphic time-line are not necessarily coincident. As discussed in more detail later, our palynostratigraphic study shows that the $\mathrm{K}-\mathrm{T}$ boundary is indeed at the base of the Tullock in some places in the basin but is below it in others.

\section{LOCALITIES AND SAMPLES}

\section{Tullock Samples}

Localities and samples from the Tullock Member are described below. The locations of sampling sites in Montana are shown in figure 3; those in Wyoming are shown in figure 4.

East Burnt Creek.-USGS paleobotany locality D6936; SE $1 / 4$ SW $1 / 4$ SW $1 / 4$ sec. 36, T. 4 N., R. 35 E., Treasure County, Mont., Hope Ranch 7.5' quadrangle; basal Tullock Member on north side of road along East Burnt Creek (tributary to Tullock Creek); K-T transition interval reported by Brown and Nichols (1988). Sample D6936-I: coal, lowest bed in Tullock, thin bed about $3 \mathrm{~m}$ above $\mathrm{K}-\mathrm{T}$ boundary and about $0.6 \mathrm{~m}$ below prominent thicker coal bed assumed to be coal bed A of Rogers and Lee (1923).

Jacobs Coulee.-USGS paleobotany locality D6940; NW $1 / 4 N^{1} 1 / 4 N^{1} / 4$ sec. 15 , T. 5 N., R. 35 E., Treasure County, Mont., Eldering Ranch 7.5' quadrangle; lower part of Tullock Member along abandoned road in Jacobs Coulee (tributary of Unknown Creek): in the extreme northwestern part of the basin. Sample D6940-BB: mudstone (gray, slightly silty), $12 \mathrm{~cm}$ below thin coal that is about $3 \mathrm{~m}$ below coal bed A of Rogers and Lee (1923). Sample D6940-AA: coal, from thin bed about $3 \mathrm{~m}$ below lowest prominent coal bed. Sample D6940-F: upper part of prominent, 90-cmthick coal (assumed to be coal bed A of Rogers and Lee, 1923).

East Beaver Creek.-USGS paleobotany locality D6937; near center NE $1 / 4 \mathrm{NE}^{1 / 4}$ sec. 34, T. 4 N., R. 37 E., Treasure County, Mont., Minnehaha Creek North 7.5' quadrangle; lower part of Tullock Member on East Beaver Creek road, near where Rogers and Lee (1923) measured 


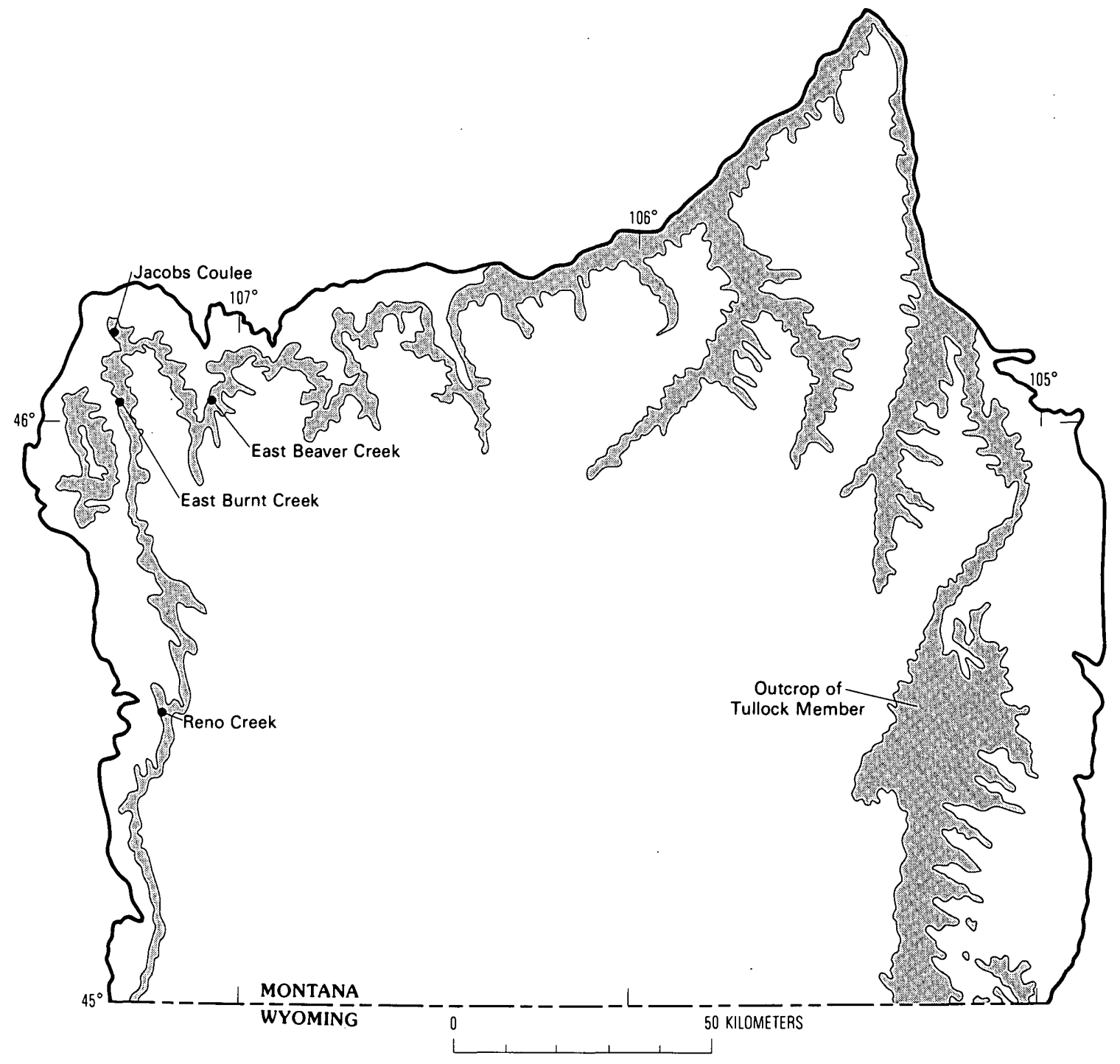

Figure 3. Sample localities in the Tullock Member of the Fort Union Formation (patterned areas), northern Powder River Basin, Montana. Outline of the basin drawn at the base of the Fox Hills Sandstone (Upper Cretaceous); location of basin shown in figure 1 .

about 90 m of "typical" Tullock. Sample D6937-D: coal, from lowermost prominent bed exposed in area, which is 46 $\mathrm{cm}$ thick (assumed to be coal bed A of Rogers and Lee). Sample D6937-H: coal, from bed about $7.5 \mathrm{~cm}$ thick that is about $3.7 \mathrm{~m}$ above coal bed A (coal bed B of Rogers and Lee?). Sample D6937-K: carbonaceous shale (black, fissile), just below probable coal bed C. Sample D6937-L: coal, from lower part of 56-cm-thick bed about $13.4 \mathrm{~m}$ above bed A (assumed to be coal bed C of Rogers and Lee).

Reno Creek.-USGS paleobotany locality D7411; SW $1 / 4$ sec. 12, T. 4 S., R. 36 E., Big Horn County, Mont., Thompson Creek NW 7.5' quadrangle; lower part of Tullock Member in bluffs north of Reno Creek on Crow Indian Reservation. Sample D7411-C: shale (tan, with plant fragments), just below 18-cm-thick coal bed that marks base of Tullock Member. Sample D7411-E: coal, lowermost part of 1-m-thick bed about $8 \mathrm{~m}$ above base of Tullock. Sample D7411-F: coal, uppermost part of 1-m-thick bed, about $9 \mathrm{~m}$ above base of Tullock. Sample D7411-I: shale (light gray to tan, with plant fragments), $23.8 \mathrm{~m}$ above base of Tullock Member. Sample D7411-J: mudstone (gray, coaly, slightly silty), $25.3 \mathrm{~m}$ above base of Tullock. Sample D7411-K: shale (tan to brown), about $30 \mathrm{~m}$ above base of Tullock.

Dry Creek.-USGS paleobotany locality D7000; NW1/4NW1/4NE $1 / 4$ sec. 6, T. 56 N., R. 69 W., Campbell County. Wyo., Bowman Hill 7.5' quadrangle; lower part of Tullock Member in bluff on cut bank of Dry Creek, south of the Montana-Wyoming State line and near the east-central margin of the basin. Sample D7000-B: carbonaceous shale (black, fissile), $4.6 \mathrm{~m}$ below base of prominent $1.4-\mathrm{m}$-thick coal bed. 


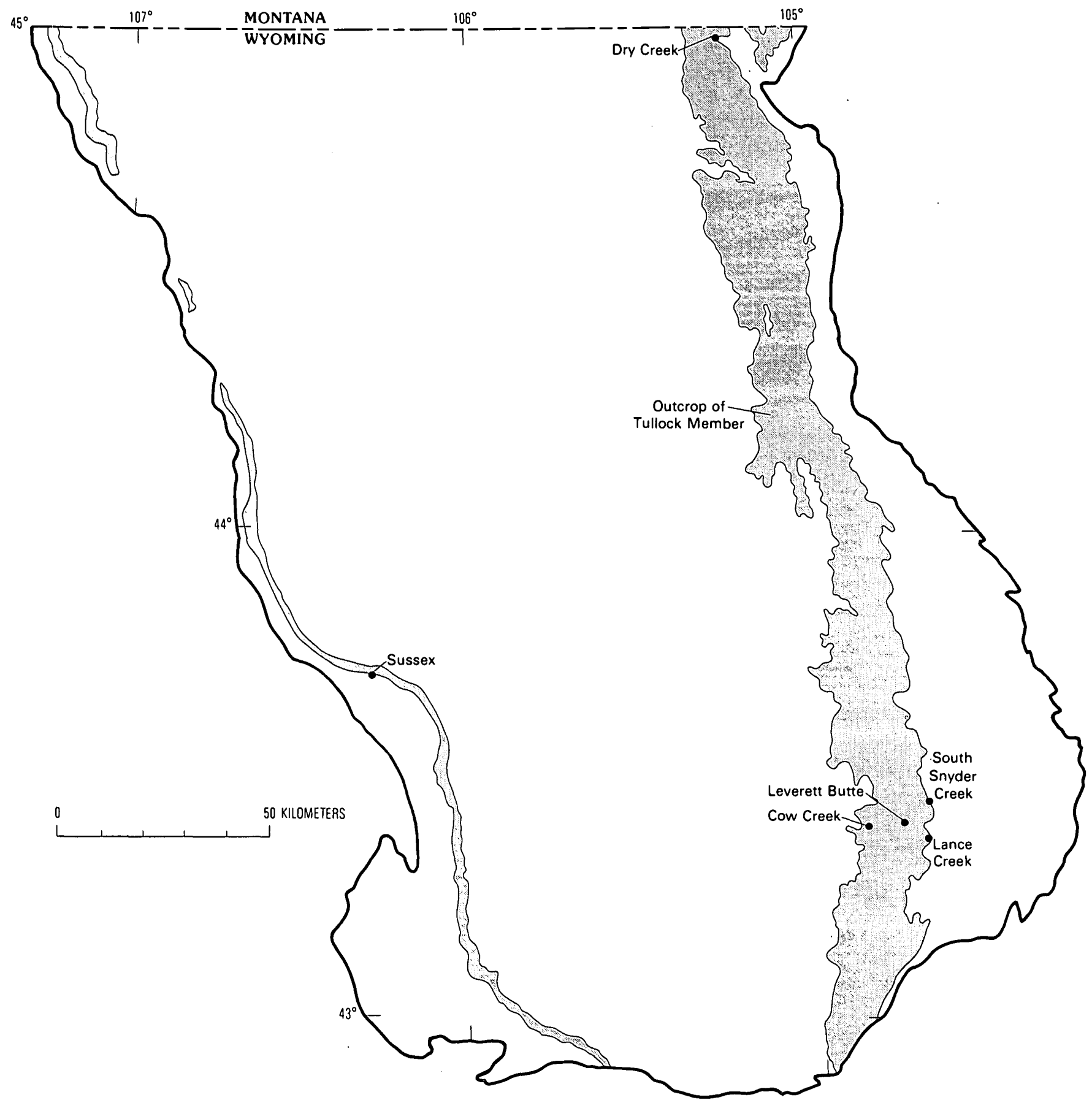

Figure 4. Sample localities in the Tullock Member of the Fort Union Formation (patterned areas), southern Powder River Basin, Wyoming. Outline of the basin drawn at the base of the Fox Hills Sandstone (Upper Cretaceous); location of basin shown in figure 1 .

Sussex.-USGS paleobotany locality D7299; SW $1 / 4$ SE $1 / 4$ sec. 3, T. 42 N., R. 79 W., Johnson County, Wyo., Sussex 7.5' quadrangle; basal Tullock Member at $\mathrm{K}-\mathrm{T}$ boundary locality of Nichols and others (in press), along the southwestern edge of the basin. Sample D7299-J: coal, lowermost $1 \mathrm{~cm}$ of basal Tullock coal, just above K-T boundary. Sample D7299-O: coal, $24 \mathrm{~cm}$ above K-T boundary. Sample D7299-R: carbonaceous shale (brown), $3.3 \mathrm{~m}$ above $\mathrm{K}-\mathrm{T}$ boundary.

Lance Creek 1.-USGS paleobotany locality D7100; SE $1 / 4$ SW $1 / 4$ SE $1 / 4$ sec. 5, T. 38 N., R. 65 W., Niobrara County, Wyo., Dixon Ranch 7.5' quadrangle; basal Tullock 
Member near K-T boundary locality of Bohor and others (1987), in the southeastern part of the basin. Sample D7100-B: mudstone (brown, slightly silty, with plant fragments), about $3.5 \mathrm{~m}$ above $\mathrm{K}-\mathrm{T}$ boundary. Sample D7100-C: carbonaceous shale (black), $5.2 \mathrm{~m}$ above $\mathrm{K}-\mathrm{T}$ boundary.

Lance Creek 2.-USGS paleobotany locality D7137; SW $1 / 4$ SW $1 / 4$ SE $1 / 4$ sec. 5, T. 38 N., R. 65 W., Niobrara County, Wyo., Dixon Ranch 7.5' quadrangle; outcrop of $\mathrm{K}-\mathrm{T}$ boundary claystone in gully west of $\mathrm{K}-\mathrm{T}$ boundary locality of Bohor and others (1987). Sample D7137-E: K-T boundary claystone. Sample D7137-G: coal, lower part of 4.5-cmi-thick bed above $\mathrm{K}-\mathrm{T}$ boundary (separated from boundary claystone layer by $3.5 \mathrm{~cm}$ of gray shale). Sample D7137-I: carbonaceous shale (brown, with plant fragments), $20 \mathrm{~cm}$ above $\mathrm{K}-\mathrm{T}$ boundary.

South Snyder Creek.-USGS paleobotany locality D7422; SW $1 / 4 \mathrm{NW}^{1 / 4} \mathrm{NE}^{1 / 4}$ sec. 8, T. 39 N., R. 65 W., Niobrara County, Wyo., Garland Draw 7.5' quadrangle; basal part of Tullock Member exposed in gully on north side of road. Sample D7422-E: shale (tan, with jarosite and plant fragments), lower parting in coal bed marking base of Tullock Member. Sample D7422-F: shale (tan, with jarosite and plant fragments), upper parting in basal Tullock coal.

Leverett Butte.-USGS paleobotany locality D7421; center to SW1/4SW1/4 sec. 27, T. 39 N., R. 66 W., Niobrara County, Wyo., Calf Draw 7.5' quadrangle; middle part of Tullock Member (based on mapping by Dobbin and others, 1957) exposed in prominent butte and adjacent gully near abandoned Leverett post office. Sample D7421-A: coal, from 13-cm-thick bed that is lowest coal exposed in gully on southwest side of road. Sample D7421-D: carbonaceous shale (black, fissile), at head of gully and about $21.6 \mathrm{~m}$ above D7421-A. Sample D7421-E: shale (brown, with jarosite and plant fragments), just above 20 -cm-thick coal bed at base of butte on northeast side of road. Sample D7421-F: mudstone (gray, silty), about $8.5 \mathrm{~m}$ above base of butte and about $30 \mathrm{~m}$ above sample D7421-A.

Cow Creek.-USGS paleobotany locality D7419; NW $1 / 4$ SW $1 / 4$ sec. 35, T. 39 N., R. 67 W., Niobrara County, Wyo., Pinnacle Rocks 7.5' quadrangle; upper Tullock Member exposed in knob on northwest side of Cow Creek Road, near Tullock-Lebo contact as mapped by Dobbin and others (1957), in the southeastern part of the basin. Sample D7419: shale (tan, with plant fragments).

\section{Stratigraphic Control Samples}

The Hell Creek Formation was sampled at the East Burnt Creek locality, and the Lance Formation was sampled at the Sussex, Lance Creek, and South Snyder Creek localities. The palynomorph assemblages recovered from these samples are typical of the upper Maastrichtian Wodehouseia spinata Assemblage Zone (Nichols and others, 1982) and differ markedly in composition from the Tullock palynoflora. The striking change in palynofloral assemblages marks the Cretaceous-Tertiary boundary in the Powder River Basin.

The Lebo Member was sampled at USGS paleobotany locality D7418 (SW1/4NW1/4 sec. 3, T. 38 N., R. 67 W., Niobrara County, Wyo., Pinnacle Rocks 7.5' quadrangle), in the southeastern part of the basin. Here the lowermost part of Lebo is exposed in a cut bank on the south side of Cow Creek, near the Tullock-Lebo contact as mapped by Dobbin and others (1957). A sample collected by Susan Foster of the Montana Bureau of Mines and Geology provided stratigraphic control in our study. That locality is USGS paleobotany locality D7591 (SW1/4SE1/4SW1/4 sec. 11, 'T. 9 S., R. 51 E., Powder River County, Mont., Wild Bill Creek $7.5^{\prime}$ quadrangle) and is in the Lebo Mernber as rnapped by Robinson and others (1964). Assemblages from these localities differ in composition from Tullock assernblages and help to determine the distinguishing characteristics of lower versus middle Paleocene palynofloras in the basin.

\section{PALYNOLOGY}

\section{General Characteristics of the Tullock Palynoflora}

The Tullock palynoflora includes at least 67 palynomorph taxa, among which 8 are listed here as "spp." (meaning that more than one species is included in the taxon); thus 75 or more different species actually are identifiable. Among the taxa discussed here, 12 are spores of bryophytes or pteridophytes (principally ferns), 6 are pollen of gymnosperms, 41 are pollen of angiosperms, and 8 are cysts of various groups of algae (principally chlorophytes).

The most commonly occurring taxa are the fern spores Cyathidites diaphana and two species of Laevigatosporites, pollen of coniferous gymnosperms assigned to Pityosporites spp., and the angiosperm pollen taxa Arecipites tenuiexinous, Tricolpites spp., and Ulmipollenites krempii, which were present in 80 percent or more of the samples examined in detail in this study. The fern spore Reticuloidosporites pseudomurii was present in 70 percent of the samples and also may be considered a characteristic species of the Tullock palynoflora. The taxa listed above are not only present at least in low number in most samples of the Tullock Member but also may be locally abundant and tend to dominate assemblages in some samples. Other taxa that are locally abundant are the fern spores Gleicheniidites sp. and Toroisporis major and the angiosperm pollen species Fraxinoipollenites variabilis, Kurtzipites circularis, and $K$. trispissatus. 
Local variations in abundance aside, the Tullock palynoflora is essentially uniform in aspect throughout the Powder River Basin. There are minor but important differences, however, in both stratigraphic and geographic distribution of individual species.

\section{Stratigraphically Restricted Taxa}

Kurtzipites circularis and K. trispissatus range into the Tullock from the underlying Cretaceous units but do not range above the Tullock and thus may be considered characteristic of the Tullock palynoflora, serving to distinguish it from the palynofloras of the Lebo and Tongue River Members. The lower part of the Tullock Member both in Montana and Wyorning contains rare occurrences of the typically Upper Cretaceous pollen species Aquilapollenites reticulatus, which has been reported previously in the lowermost Paleocene in Alberta (Jerzykiewicz and Sweet, 1986). Three biostratigraphically important species of the angiosperm pollen genus Momipites ( $M$. leffingwellii, $M$. waltmanensis, and $M$. wyomingensis) are present only in the middle and upper parts of the Tullock. These species indicate that the middle and upper parts of the Tullock Member are within palynostratigraphic zone P2 of Nichols and Ott (1978) and are of late early Paleocene age. The absence of Momipites leffingwellii from the lower part of the Tullock in the Powder River Basin indicates a significant difference between the palynostratigraphic definition of zone P1 in this basin and that for the Wind River Basin, where the zone was originally defined (Nichols and Ott, 1978). The absence from the Tullock Member of other biostratigraphically important palynomorphs is also significant. Momipites anellus, $M$. triorbicularis, $M$. ventifluminis, and Aquilapollenites spinulosus, which are characteristic of lower middle Paleocene zone P3 of Nichols and Ott (1978), were not found in any of the Tullock samples but were found in the lower part of the overlying Lebo Member of the Fort Union Formation in the eastern and southern parts of the basin.

\section{Geographically Restricted Taxa}

Species of the morphologically unique and biostratigraphically important pollen genus Wodehouseia (W. fimbriata and W. spinata) were found only in the Montana part of the Powder River Basin in this study. Wodehouseia fimbriata is a characteristic species of palynostratigraphic zone P2 in Alberta (Demchuk, 1990) but is near the southern limit of its paleogeographic range in the Powder River Basin and is rarely found in the Paleocene of the United States. Wodehouseia spinata is another typically Upper Cretaceous species that, like Aquilapollenites reticularus, persists into the lowermost Paleocene in southern
Canada (Jerzykiewicz and Sweet, 1986). Two pollen species, Liliacidites leei and Retitrescolpites anguloluminosus, were found only in samples from the Wyoming part of the basin. Both were originally described from the Paleocene of New Mexico (Anderson, 1960) and probably represent elements of a southern flora that were near the northern limits of their paleogeographic ranges in Wyoming.

\section{Lithofacies Associations}

The general uniformity of the Tullock palynoflora with respect to occurrences of most taxa extends to the lithofacies associations of the palynomorphs. That is, most taxa can be found in all fine-grained, non-oxidized sedimentary rocks within the Tullock, including mudstone, shale, carbonaceous shale, and coal. There are a few exceptions, but they most likely are of little importance. Within the limits of this study, some of these occurrence patterns may be artifacts of sampling. The probable bryophtye spore Zlivisporis novomexicanum and the palynomorph designated algal cyst type 3 were found in all rock types named above except coal; spores of the aquatic fern Ghoshispora bella and algal palynomorphs designated Tetraporina sp. and algal cyst type 2 were not found in samples of shale (except carbonaceous shale). The general uniformity of distribution of the Tullock palynoflora on a presence/absence basis is a fortunate circumstance for biostratigraphy because if local plant communities had too strong an influence on composition of palynomorph assemblages, those assemblages would be of limited use in age determination. All Tullock palynomorph assemblages are not alike, however, and, especially when relative abundances of taxa such as those mentioned previously are considered, it is possible to derive information about the kinds of plant communities that inhabited the Powder River Basin in early Paleocene time.

\section{Paleocene Plant Communities}

The peat-forming mires that eventually formed the coal deposits of the Tullock Member were not forested swamps dominated by taxodiaceous trees (relatives of living Taxodium or Glyptostrobus), as were those that formed coals of the Tongue River Member of the Fort Union Formation (described by Pocknall and Flores, 1987). Tullock mires were inhabited mostly by ferns. In this study nine Tullock coal beds were studied in detail, beds from a few centimeters to $1 \mathrm{~m}$ thick. Fern spores are the most numerous palynomorphs in all of them, especially the species of Laevigatosporites, Reticuloidosporites, and Cyathidites, although all have fairly diverse palynomorph assemblages reflecting fairly diverse plant communities. Spores of 
species of Stereisporites, which were produced by bryophytes closely related to living sphagnum moss, are prominent in some assemblages from Tullock coals. Tullock coal assemblages thereby contrast markedly with most Tongue River coal assemblages, which tend to be low in diversity and dominated by pollen of taxodiaceous conifers (Pocknall and Flores, 1987). Taxodiaceous pollen (here ascribed to Taxodiaceaepollenites hiatus) is present in many Tullock samples but always as a relatively minor component of assemblages. Smaller amounts of biomass presumably produced by fern-dominated mires rather than by swamps dominated by coniferous trees may account in part for Tullock coals being generally thinner and less laterally extensive than Tongue River coals.

All Tullock sediments and their contained palynomorphs were deposited in periodically wet to subaquatic environments, but some show clearer evidence of the presence of wetland plant communities than do others. Sample D7000-B, a fissile carbonaceous shale from the Dry Creek locality, yielded an unusually diverse assemblage including the angiosperm pollen Pandaniidites typicus, which is probably related to living Pandanus, most species of which inhabit marshy areas; Penetetrapites inconspicuus, which has morphological resemblance to pollen of living sedges; and Sparganiaceaepollenites sp., which probably is related to living marsh grass (Sparganium) or cattail (Typha). Also present in this assemblage are massulae and microspores of Azolla cretacea, an aquatic fern; spores of Stereisporites (Sphagnaceae, mosses); and cysts of aquatic algae, including Schizophacus sp., which is related to the living chlorophyte alga Spirogyra; Tetraporina sp., which is related to the living chlorophyte alga Mougeotia; and algal cyst type 3 . Sample D7100-C, a carbonaceous shale from locality Lance Creek 1 , yielded an assemblage that includes Pandaniidites typicus, Penetetrapites inconspicuus, Azolla cretacea, algal cyst type 3, and unusual numbers of spores of the aquatic fern Ghoshispora bella. Sample D6937-K, a fissile carbonaceous shale from beneath a coal bed at the East Beaver Creek locality, yielded an unusual abundance and variety of freshwater algal cysts, including Schizophacus laevigatus, which is related to living Spirogyra; Sigmopollis hispidus; Tetraporina sp.; and forms of uncertain affinity designated algal cyst types 1 and 2. Open, standing freshwater is indicated by these species of algal cysts. Also present in the assemblage from this sample is Sparganiaceaepollenites $\mathrm{sp}$. The assemblages of all three samples suggest the presence of wetland environments.

Samples that have unusual concentrations of palynomorphs of one or a very few species may reflect local plant communities. The angiosperm pollen species Kurtzipites circularis dominates the assemblage from sample D7419, shale from the upper part of the Tullock at the Cow Creek locality. Using multivariate analysis, Fleming (1990) determined that lower Paleocene assemblages from the
Raton basin of Colorado and New Mexico that were dominated by this species are indicative of marsh environments. Presence of a similar marsh plant assemblage in sample D7419 is further supported by occurrences of pollen of Sparganiaceaepollenites and the algal cysts Schizophacus laevigatus and Schizophacus sp. Sample D7137-I, carbonaceous shale from locality Lance Creek 2, is dominated by the angiosperm pollen species Fraxinoipollenites variabilis, but the ecological significance of this species is not known. The only other noteworthy feature of the assemblage from D7137-I is the presence of some reworked Cretaceous marine and nonmarine palynomorphs. Assemblages from coal samples that are dominated by fern spores or have concentrations of sphagnaceous spores were discussed above. They indicate the composition of plant communities of peat-forming mires.

In contrast with plant communities of local environments, the most commonly occurring palynomorph taxa provide insight into the nature of the regional flora of the Powder River Basin in early Paleocene time. As mentioned, these taxa include fern spores assigned to the genera Cyathidites, Laevigatosporites, and Reticuloidosporites; conifer pollen assigned to Pityosporites; and three angiosperm pollen taxa, Arecipites tenuiexinous, Tricolpites spp., and Ulmipollenites krempii. The ferns probably were most common in the wet lowland environments that included peat-forming mires. The conifer pollen, which is persistent in occurrence but nowhere dominant in the Tullock, probably was transported to the depositional area from adjacent upland areas to the west. The abundance of Arecipites tenuiexinous, pollen most likely produced by palms, attests to the presence of thermophilic vegetation and suggests that palms were included among the forests in Tullock time. Species of Tricolpites and Ulmipollenites krempii probably were produced by deciduous trees such as ancestral members of the modern families Platanaceae and Ulmaceae, respectively, which evidently were prevalent in the Powder River Basin in the early Paleocene.

\section{Palynostratigraphy and Age}

The $\mathrm{K}-\mathrm{T}$ boundary is a precise chronostratigraphic datum in the Powder River Basin. It has been defined within centimeters at two sites that were also sample localities in the present study, Lance Creek in the southeastern part of the basin (Bohor and others, 1987) and Sussex in the southwestern part of the basin (Nichols and others, in press). At both localities an abrupt change in palynologic assemblages coincides with an anomalous concentration of iridium and the presence of shock-metamorphosed quartz grains. The $\mathrm{K}-\mathrm{T}$ boundary also was bracketed within several meters at the East Burnt Creek locality in the northwestern part of the basin during this study (Brown and Nichols, 1988). The iridium anomaly was not located at East Burnt Creek, presumably because the higher energy 
depositional environment prevented deposition of the typical K-T boundary claystone. Rocks of the Lance and Hell Creek Formations at all three K-T boundary localities in the Powder River Basin yield palynomorphs characteristic of the Wodehouseia spinata Assemblage Zone, a palynologic biozone known throughout the central and northern Rocky Mountain region (Nichols and others, 1982). Palynologic assemblages from rocks of the Tullock Member above the $\mathrm{K}-\mathrm{T}$ boundary lack this assemblage. The Tullock Member assemblages include the palynomorphs discussed in this report. There are important implications for the age of the Lance and Hell Creek Formations and the Tullock Member of the Fort Union Formation that follow from detailed analysis of the K-T boundary.

In the Lance Creek area Clemens (1964) placed the Lance-Fort Union contact at the base of the lowest persistent coal bed above the stratigraphically highest dinosaur remains, using the "formula" of Calvert (1912) as espoused by Brown (1962). In the Lance Creek area the lowest persistent coal is a bed about $0.6 \mathrm{~m}$ thick. Leffingwell (1970) noted that the palynologically defined K-T boundary is about $9.5 \mathrm{~m}$ below the formation contact as designated by Clemens. Leffingwell recommended lowering the position of the formation contact to the base of a thin (about $18 \mathrm{~cm}$ ) coal bed from which his lowest Tertiary sample was collected. Bohor and others (1987), who precisely located the $\mathrm{K}-\mathrm{T}$ boundary within the equivalent interval near the section studied by Clemens and Leffingwell, placed the formation contact at the base of a coal bed $3-4 \mathrm{~cm}$ thick. Neither Leffingwell nor Bohor selected coal beds that meet Brown's criterion of being "persistent." It is not even clear that the thin bed selected in each case was the same one. Leffingwell's diagram (1971, fig. 4) shows a second thin (about $2.5 \mathrm{~cm}$ ) coal below the one he selected as the base of the Fort Union and above his highest Cretaceous sample. That coal could be Cretaceous, or, if it is Tertiary, it could be equivalent to the one illustrated by Bohor and others (1987, fig. 3). More likely, none of these thin beds persists laterally for any significant distance. The formation contact is best recognized where Clemens placed it, at the thicker, persistent bed, which is a mappable horizon. In any event, as much as 9 or $10 \mathrm{~m}$ of the upper part of the Lance Formation in the Lance Creek area is earliest Paleocene in age.

At the East Burnt Creek locality it is evident that the uppermost part of the Hell Creek Formation is earliest Paleocene in age. This assumes that the base of the Tullock Member of the Fort Union in this area is taken to be the base of the lowest persistent coal bed in that area, coal bed A of Rogers and Lee (1923). In our study of the area (Brown and Nichols, 1988), we found the highest Cretaceous palynomorph assemblage to be $4.3 \mathrm{~m}$ below coal bed A. A sample having poor recovery but probably Paleocene in age was collected $2.4 \mathrm{~m}$ above the highest Cretaceous sample and about $1.3 \mathrm{~m}$ below coal bed $\mathrm{A}$. The situation is potentially complicated by a color change, from greenish gray below to buff above, which also has been used as a field criterion to distinguish the Hell Creek and Fort Union Formations and which occurs $7.6 \mathrm{~m}$ below coal bed A along East Burnt Creek. If the base of the Tullock was placed at the color change instead of at the base of the coal, as much as $3 \mathrm{~m}$ or more of the basal Tullock would be Cretaceous in age. We place the formation contact at the base of the lowest coal (coal bed A) at East Burnt Creek, which leaves the Tullock entirely Paleocene.

At the Sussex K-T boundary locality there are no such problems because the formation contact and the $\mathrm{K}-\mathrm{T}$ boundary coincide. Samples just below the lowest coal above the highest dinosaur remains yield palynomorphs of the Wodehouseia spinata zone and the coal yields typical Tullock palynomorphs (Nichols and others, 1992).

The basal part of the Tullock Member is early Paleocene in age and presumably equivalent to palynostratigraphic zone P1 of Nichols and Ott (1978). The age determination is based on the stratigraphic relations of the basal Tullock and the $\mathrm{K}-\mathrm{T}$ boundary. The composition of basal Tullock palynomorph assemblages does not completely match that of zone P1 assemblages from the Wind River Basin, however. Differences may be attributed to interbasinal variation in floras in earliest Paleocene time, but, because the K-T boundary was not precisely located in the Wind River Basin, it is possible that zone P1 does not actually represent the basal Paleocene there. The present study is a more extensive and more complete analysis of the nature of the lower Paleocene palynoflora of the Rocky Mountain region than was that of Nichols and Ott (1978), which concentrated on definition of palynostratigraphic zones based on a few biostratigraphically important species.

The middle and upper parts of the Tullock Member are within palynostratigraphic zone P2 of Nichols and Ott (1978) and are of late early Paleocene age. This age determination is based on comparison of assemblages from the Wind River and Powder River Basins and on the composition of assemblages from our stratigraphic control samples from the lower part of the Lebo Member of the Fort Union Formation in the Powder River Basin. The Lebo samples yielded assemblages characteristic of lower middle Paleocene zone P3 of Nichols and Ott (1978).

Lithologic changes between the underlying Lance and Hell Creek Formations and the Tullock Member or between the Tullock and the overlying Lebo Member cannot account for the changes in palynomorph assemblages on which our palynostratigraphy is based. Local depositional environment can affect the kinds of plants that are present and therefore the kinds of palynomorphs that tend to be preserved in sediments, but the differences in assemblages discussed above are regional in extent and independent of lithology. The changes that mark the K-T boundary are now known throughout western North America (references in Nichols and others, in press). The changes in assemblages 
Table 1. Alphabetical list of palynomorph taxa from the Tullock Member discussed in this report, with full nomenclatural citations

[Page numbers in brackets refer to location of discussion of the taxa in this report]

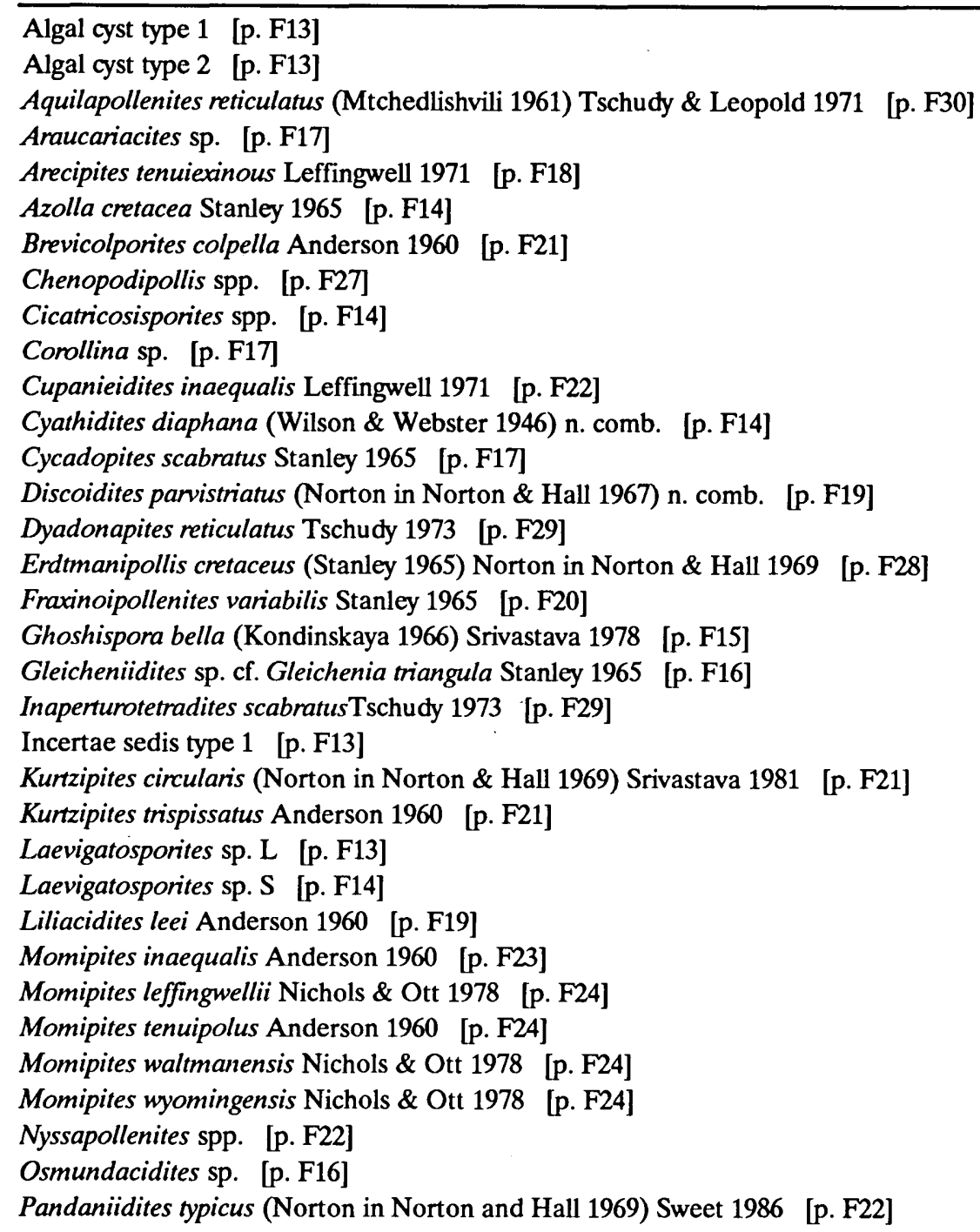

from zone P2 to P3 that coincide with the Tullock-Lebo transition in the Powder River Basin were defined within a single lithostratigraphic unit in the Wind River Basin, the lower unnamed member of the Fort Union Formation. Finally, the most commonly occurring taxa of the Tullock palynoflora were recovered from all fine-grained rock types sampled in our study.

\section{Descriptions of Palynomorph Taxa}

Palynomorph taxa in the Tullock palynoflora are discussed in the following sections, in which they are grouped according to their presumed botanical affinity and then in major morphologic categories. Within each morpho- logic category, the sequence is alphabetical. Table 1 is a list of all taxa discussed, arranged alphabetically and with full nomenclatural citations and page-number references to the following section.

\section{Algal Cysts}

Schizophacus laevigatus (Stanley) n. comb.

Plate 1, figure 1

Basionym: Schizosporis laevigatus Stanley, 1965, p. 268-269, pl. 23, figs. 6, 7; pl. 37, figs. 4, 5 (non Schizosporis laevigatus Venkatachala, 1969, p. 216 , pl. 6, figs. 13-15).

Schizophacus laevigatus (Stanley) n. comb. includes elongate, biconvex bodies, ovoid in outline, that tend to split into two equal halves along a simple line of dehiscence that 
Table 1. Alphabetical list of palynomorph taxa from the Tullock Member discussed in this report, with full nomenclatural citations-Continued

[Page numbers in brackets refer to location of discussion of the taxa in this report]

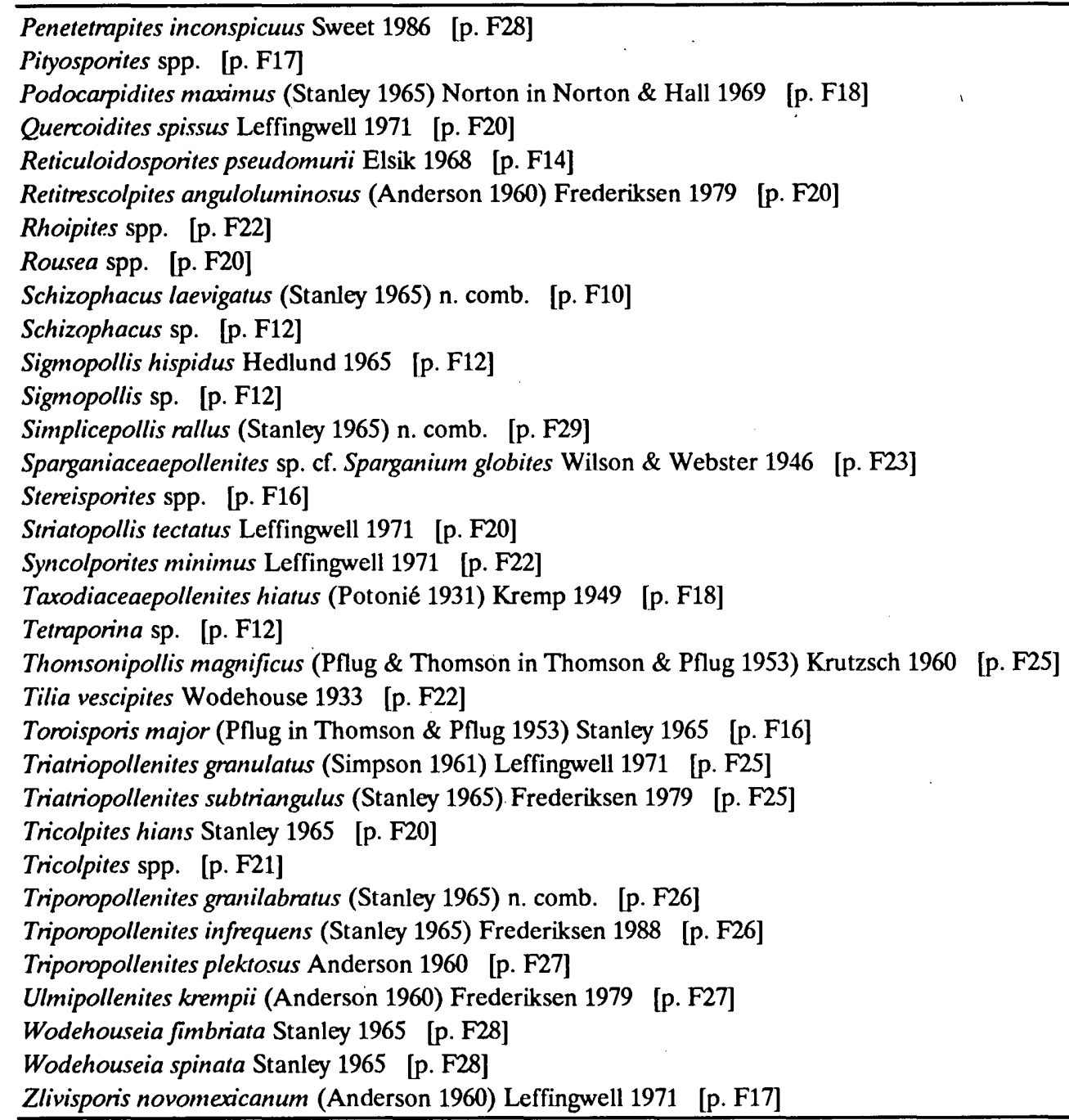

encircles the body lengthwise. The wall is single-layered and psilate. Ten Tullock specimens measured were from 57 to $98 \mu \mathrm{m}$ in maximum dimension. Specimens described by Venkatachala (1969) as Schizosporis laevigatus are similar but are larger and have thicker walls; if that species is not synonymous with Schizophacus laevigatus n. comb., the name Schizosporis laevigatus Venkatachala is a homonym of Schizosporis laevigatus Stanley and should be replaced.

Van Geel (1976) identified Holocene specimens that are morphologically identical with the Tullock fossils as algal cysts, more precisely as zygospores or aplanospores of the modern zygnemataceous chlorophyte alga Spirogyra. Rich and others (1982) assigned identical forms from Holocene peats to Ovoidites Potonié ex Krutzsch and elucidated their paleoecological significance. On the basis of their observations and the identification by Van Geel, Rich and others concluded that these fossils are indicators of freshwater marshes. They noted that identical forms have been reported from rocks as old as Cretaceous. Despite their value in paleoecological interpretation, considerable taxonomic and nomenclatural confusion centers on these fossils and similar forms that have been classified with them. These problems are briefly reviewed here to clarify the nomenclature applied to the Tullock specimens.

The name Ovoidites was proposed by Potonié (1951) for specimens from the Eocene of Germany; the genus was validated by Krutzsch (1959), who redescribed it and designated a type species, Oroidites ligneolus (Potonié). In their descriptions, both Potonié and Krutzsch emphasized the general form of the fossils and their tendency to split into two equal halves. Neither author specified the structure or sculpture of the cyst wall. Cookson and Dettmann (1959) described the genus Schizosporis for certain fossils from the Upper Cretaceous of Australia that also tend to split into 
equal or subequal, discoidal halves but that have complexly structured, multilayered walls. The type species of Schizosporis is especially distinctive in having a robustly reticulate wall, and it differs markedly from the fossils we discuss here. Their species Schizosporis parvus and S. spriggi bear a general resemblance to the Tullock specimens and those from the Holocene deposits mentioned above, in form and in having a psilate wall, but they were described as having thick, multilayered walls. Potonié (1966) redescribed both Ovoidites and Schizosporis and reillustrated them using line drawings that make them appear more different from one another than is apparent from his redescriptions, both of which again emphasize reticulate walls.

A resolution of the confusion was provided by Pierce (1976), who redescribed Schizosporis reticulatus and emended the genus Schizosporis to include forms with complex, reticulate walls that are almost multicellular in appearance, and who proposed the genus Schizophacus. Schizophacus includes lenticular forms that split along an equatorial suture and that have psilate walls or walls sculptured with patterns in low relief. The Tullock specimens illustrated here fall within the circumscription of Schizophacus. The specimens illustrated and discussed by Rich and others (1982) also are clearly referable to Schizophacus; the genus Ovoidites has uncertain nomenclatural status.

Schizophacus laevigatus (Stanley) n. comb. closely resembles "spore type C" of Van Geel (1976, pl. 1, figs. 5-8), which was identified as a cyst produced by a species of the modern genus Spirogyra. In the Tullock Member, $S$. laevigatus was present in 13 samples studied. Its occurrence is not restricted by lithology. It was most abundant in sample D6937-K, a carbonaceous shale just below a coal bed at the East Beaver Creek locality, where it is part of an assemblage notable for its abundance of algal cysts and interpreted to represent a freshwater marsh environment that preceded development of a peat-forming mire.

\section{Schizophacus sp.}

Plate 1, figure 2

Samples from the Tullock Member yielded a second species referable to Schizophacus, which we designate Schizophacus sp. These specimens resemble $S$. laevigatus (Stanley) n. comb. in all respects except that the wall is characterized by subtle sculpture consisting of low ridges that form a pattern suggestive of a weakly developed reticulum. Van Geel (1976, pl. 1, fig. 11) illustrated a closely similar specimen he designated "spore type D" and identified as a zygospore or aplanospore of a species of the modern genus Spirogyra. Rich and others (1982, pl. 1, figs. 6 , 7) illustrated closely similar specimens from Holocene freshwater peats deposits in the Okefenokee Swamp, Georgia. They interpreted the sculpture pattern to be a wrinkled perispore. Tullock specimens have a single wall layer and no evidence of a separate perispore. Rich and others assigned their specimens to the genus Ovoidites; refer to the nomenclatural history of Schizophacus and Ovoidites discussed above.

Schizophacus sp. was present in nine Tullock samples studied; its occurrence is not restricted by lithology. It was present in two samples in which Schizophacus laevigatus was not present; thus in both morphology and occurrence these two species are distinct. Evidently both are cysts of algae related to the modern genus Spirogyra. In the Tullock, Schizophacus sp. is associated with cysts of other aquatic algae and pollen of marsh plants, as in sample D7000-B from the Dry Creek locality.

\section{Sigmopollis hispidus Hedlund}

Plate 1, figure 3

The algal cyst Sigmopollis hispidus was first reported by Hedlund (1965) and later by Wingate (1983) from the lacustrine Elko Shale (Eocene and Oligocene) in Nevada. It is spheroidal and has a unique sigmoidal line of dehiscence on one side. Specimens reported from lacustrine shales of the Green River Formation (Eocene) as Sigmopollis sp. by Nichols (1987) probably are conspecific. Close morphologic similarity between these Tertiary fossils and Holocene specimens illustrated by Pals and others (1980, pl. 2, figs. $128 \mathrm{a}-\mathrm{e})$ is evident. The evidence from ancient and submodern environments suggests that Sigmopollis hispidus is an indicator of freshwater aquatic environments.

In the Tullock Member samples we studied, Sigmopollis hispidus was present only in D6937-K, the carbonaceous shale below coal bed $\mathrm{C}$ at the East Beaver Creek locality. This deposit is also characterized by other algal cysts in abundance. It evidently represented a local lacustrine environment that was succeeded by a peat mire.

\section{Sigmopollis sp.}

Plate 1, figure 4

Sigmopollis sp. closely resembles $S$. hispidus in morphology but lacks the spines that characterize the latter species. The close morphologic resemblance of the two palynomorphs, which differs from that known in spores or pollen of terrestrial plants, suggests that Sigmopollis sp., like $S$. hispidus, is the cyst of an aquatic alga. Both forms were recorded only from sample D6937-K in this study.

\section{Tetraporina spp.}

Plate 1, figures 7,8

Tetraporina spp. from the Tullock Member includes quadrate to concavely quadrate forms that vary in size and have either smooth or lightly sculptured cyst walls. The corners have structures suggestive of dehiscence areas but 
no true apertures. The form genus Tetraporina includes fossil algal cysts of the kind illustrated by Van Geel (1976, pl. 1, figs. 1-3) and identified as zygospores of the modern zygnemataceous chlorophyte Mougeotia sp. cf. M. punctata. More than one species probably is represented by fossil specimens from the Tullock Member.

The complicated nomenclatural history of the genus Tetraporina was reviewed in detail by Jansonius and Hills (1981). Authorship and typification finally have been established, but unfortunately the genus is still described as encompassing tetraporate pollen, although it now seems clear that specimens appropriately referred to it actually are nonporate algal cysts. The specimens described by Van Geel (1976) were from the Holocene of the Netherlands. The genus Tetraporina is based on specimens originally described from the lower Carboniferous of Russia. Thus, these algal cysts, which are characteristic of freshwater environments, are from an ancient lineage. Jarzen (1979) illustrated many specimens referable to Tetraporina from the Ravenscrag Formation in Saskatchewan, which is in part correlative with the Tullock Member of the Fort Union Formation.

Tullock specimens of Tetraporina spp. were found in several samples of coal and carbonaceous shale, and in one mudstone sample. In the Tullock, Tetraporina spp. generally is present with other algal cysts, especially Schizophacus spp.

\section{Algal cyst type 1}

Plate 1, figure 5

Palynomorphs assigned to the informal taxon "algal cyst type 1 " in this study are small (diameter about $25 \mu \mathrm{m}$ ), spheroidal, psilate forms that have a simple dehiscence mark along which they split. They differ from specimens here assigned to Sigmopollis sp. in slightly larger size and in having a straight rather than sigmoidal dehiscence mark. They are interpreted to be of algal origin because their morphology does not resemble that of spores or pollen of any known terrestrial plants. Their exact affinity is unknown.

These cysts were present in only one sample, D6937-K, a carbonaceous shale from the East Beaver Creek locality that was independently interpreted to be of lacustrine origin. They were fairly common in this sample.

\section{Algal cyst type 2}

Plate 1, figure 6

Palynomorphs assigned to the informal taxon "algal cyst type 2 " in this study are small (diameter about $20 \mu \mathrm{m}$ ), spheroidal, echinate forms that have a simple dehiscence mark along which they split. They resemble algal cyst type 1 except in being densely covered with tiny, slender spines, and they resemble Sigmopollis hispidus except in having a straight rather than sigmoidal dehiscence mark. Like algal cyst type 1 , they are assumed to be of algal origin because their morphology is unlike that of any known pollen or spores.

Specimens of this morphology were present in four samples from the Tullock Member, in coal, carbonaceous shale, and mudstone. Specimens were most abundant in the lacustrine carbonaceous shale sample D6937-K from the East Beaver Creek locality.

\section{Alete Spores}

Incertae sedis type 1

Plate 1 , figures 9,10

Palynomorphs designated "incertae sedis type 1 " in this study are small (diameter $20-30 \mu \mathrm{m}$ ), inaperturate, spheroidal, coarsely reticulate forms. About one-third of the diameter is accounted for by the reticulum, which has high, thin muri and large, homobrochate lumina. Although reticulate sculpture is common among angiosperm pollen and also characterizes some kinds of pteridophyte spores, we know of no pollen or pteridophyte spores that are both inaperturate and reticulate. These fossils may be bryophyte spores. Spores of the modern bryophyte genus Fossombronia illustrated by Erdtman (1957) have similar sculpture and obscure apertures, although they differ from the fossils in size and shape.

Incertae sedis type 1 was present in five Tullock samples, including all the non-coal rock types studied. The possibility that this palynomorph is of freshwater algal origin is suggested by the observation that it is present in assemblages that include the water fern Azolla cretacea and, in some samples, algal cysts of the genera Schizophacus and Tetraporina.

\section{Monolete Spores}

Laevigatosporites sp. L

Plate 1, figures 11-14

Psilate, monolete spores referable to the form genus Laevigatosporites are among the most common fossils in the Tullock Member. Spores of this morphology were present in all samples studied, and they were especially common in some. As a group, they range in size from 25 to $60 \mu \mathrm{m}$; they exhibit no other morphologic variation that would permit recognition of individual botanical species that may be represented.

Size/frequency distribution counts were made on two samples in which these spores were especially common: D6937-D and D7411-C, both of which are coals. In 
D6937-D the size range is $25-58 \mu \mathrm{m}$ and the modal size 34 $\mu \mathrm{m}$, although many are of larger size (225 specimens measured). In D7411-C, in which these spores are the numerical dominants, the range is $37-60 \mu \mathrm{m}$ and the mode 50 $\mu \mathrm{m}$ (100 specimens measured). Thus it is likely that two species can be distinguished on the basis of size.

Laevigatosporites $\mathrm{sp} . \mathrm{L}$ is the larger of two species of the genus distinguishable within the Tullock palynoflora. It is one of the most common species in the Tullock. As informally defined here, species $\mathrm{L}$ includes specimens from 40 to $60 \mu \mathrm{m}$ long; most are about $50 \mu \mathrm{m}$ long.

Laevigatosporites $\mathrm{sp} . \mathrm{L}$ was present in all rock types and in almost all samples. It is the numerically dominant species in sample D7411-C. Patterns of occurrence and relative abundance show that this species is distinct from Laevigatosporites sp. S, although these two species differ only in size. Laevigatosporites sp. L was produced by polypodiaceous ferns that were major components of Tullock plant communities, especially in mire environments.

\section{Laevigatosporites sp. S}

Plate 2, figures $1-5$

Laevigatosporites $\mathrm{sp} . \mathrm{S}$ is the smaller of two species of the genus present in the Tullock palynoflora. As here informally defined, species $S$ includes specimens from 25 to $40 \mu \mathrm{m}$ long; most are about $35 \mu \mathrm{m}$ long. Wilson and Webster (1946) described two species of Laevigatosporites, $L$. ovatus and $L$. gracilis, that differed in size and proportions, the former being larger and more rounded in outline than the latter. All of their specimens are within the size range of Laevigatosporites $\mathrm{sp}$. S; we observed no consistent variation in proportions among Tullock specimens of the genus other than those attributable to orientation and compression.

This species was present in all rock types and in almost every sample. Laevigatosporites $\mathrm{sp}$. $\mathrm{S}$ was produced by polypodiaceous ferns that were major components of Tullock plant communities, especially in peat-forming mires.

\section{Reticuloidosporites pseudomurii Elsik}

Plate 2, figures 6,7

Reticuloidosporites pseudomurii includes monolete spores that have low, irregular verrucae that tend form a poorly developed reticulate pattern. The distinctive sculpture serves to distinguish these spores from the otherwise similar Laevigatosporites spp.

The relative abundance of $R$. pseudomurii in the Tullock is generally less than that of the species of Laevigatosporites, although it was present in 23 of the 30 samples studied in detail and it was the dominant species in sample D7299-O, one horizon within the coal bed at the Sussex locality. Distribution data published by Leffingwell (1971, pls. 1, 2) show that Reticuloidosporites pseudomurii is relatively more abundant in the Tullock than in the underlying Cretaceous or in the overlying members of the Fort Union Formation.

\section{Trilete Spores}

\section{Azolla cretacea Stanley}

Plate 2, figures $8-10$

Azolla cretacea is a species of heterosporous aquatic fern represented in the Tullock Member by microspores, which are small, circular in outline, and trilete, and by massulae, which are large, irregularly shaped bodies characterized by distinctive, anchor-shaped glochidia. Isolated glochidia may be encountered in preparations.

This species was first described from the Hell Creek Formation and the Ludlow Member of the Fort Union Formation in South Dakota, on the basis of massulae (Stanley, 1965). Leffingwell (1970, pl. 4, fig. 1) identified microspores of Azolla cretacea in the Lance Formation and Tullock Member of the Fort Union in Wyoming. The significance of this species as an indicator of lacustrine environments in the Fort Union was first recognized by Tschudy (1961).

In our study, Azolla cretacea was recorded in six samples, all from the lower part of the Tullock Member. This pattern of occurrence agrees with that shown by Leffingwell $(1970$, pls. 1, 2). A. cretacea tended to be present in assemblages that also include the aquatic algae Schizophacus and Tetraporina.

\section{Cicatricosisporites spp.}

Plate 2, figure 12

This taxon includes one or more species of striate or cicatricose trilete spores; no attempt was made to identify individual species because so few of these spores were encountered. As shown by their distinctive sculpture, they were produced by ferns of the family Schizaeaceae. They were recorded as relatively rare specimens in six samples and were somewhat more common in the northern part of the basin than in the southern part. Ferns producing these spores probably were components of the regional flora and were not associated with any particular plant community.

\section{Cyathidites diaphana (Wilson \& Webster) n. comb.}

Plate 3, figures 3-5

Basionym: Deltoidospora diaphana Wilson and Webster, 1946, p. 273, fig. 3.

Dettmann (1963) clarified the distinctions between the closely similar genera of triangular, psilate trilete spores Cyathidites and Deltoidospora. Cyathidites includes those 
having concave sides (and rounded apices); Deltoidospora includes those having straight sides (and sharper apices). Spores conforming to the morphology of Cyathidites, which are among the most abundant and commonly occurring in the Tullock palynoflora, were first described by Wilson and Webster (1946) from a Fort Union coal in southwestern Montana but were assigned to Deltoidospora. Stanley (1965, p. 248) transferred Wilson and Webster's species to the obscure genus Cardioangulina, which, if it is not different in being trilobate in form and much larger, is synonymous with Cyathidites. Leffingwell (1970, pls. 1, 2) apparently assigned his Tullock specimens of Cyathidites diaphana to a group he designated "unornamented trilete spores." Norton and Hall (1969) assigned theirs to Cyathidites.

Cyathidites diaphana was present in every sample except that from the uppermost part of the Tullock Member at the Cow Creek locality. This pattern of stratigraphic occurrence is consistent with that shown by Leffingwell (1970, pls. 1, 2) for "unornamented trilete spores" and indicates that Cyathidites diaphana is a characteristic species of the Tullock palynoflora. This species is especially abundant just above the Cretaceous-Tertiary boundary at the Sussex and Lance Creek 2 localities (see also discussion of the fern-spore abundance anomaly in Nichols and others, in 1992).

\section{Choshispora bella (Kondinskaya) Srivastava}

Plate 2, figures 13,14 ; plate 3 , figures 1,2

Ghoshispora bella encompasses ornately ornamented, acrolamellate, trilete spores that may have been produced by heterosporous aquatic ferns (see Tschudy, 1961). If they are megaspores in the botanical sense, they are unusually small and are recovered in the same preparations as other palynomorphs; Tullock specimens are from 45 to $65 \mu \mathrm{m}$ in diameter, excluding acrolamellae. The sculpture is coarsely echinate, and the echinae have ribs radiating from their bases that tend to form a reticulate pattern by connecting adjacent echinae. Specimens are common in the Campanian and Maastrichtian of the Rocky Mountain region, and the synonymous species Styx minor was regarded as characteristic of the Upper Cretaceous of Montana by Norton and Hall (1967). Their occurrence, however, is controlled by depositional environment as well as stratigraphic age. The nomenclatural history of this species has been complicated by competing taxonomic concepts discussed below.

Srivastava (1967) described similar large, ornate spores from the Maastrichtian of Alberta as species of a new genus, Ghoshispora. His description emphasizes presence of an easily detached perine and makes no mention of the acrolamellae, the leaflike extensions of the laesurae. Specimens conspecific with ours from the Tullock Member were described from the Hell Creek Formation in Montana as a new genus and species, Styx minor, by Norton and Hall (1967), who also made no mention of acrolamellae. They also described a larger but otherwise similar species, $S$. major, from the same deposits, and mixed up the illustrations of the type specimens of the two species (Norton and Hall, 1969, p. 24); correctly labeled specimens were reillustrated by them in their 1969 paper. That same year, Srivastava and Binda (1969) described similar specimens from the Upper Cretaceous of Alberta and Saskatchewan as species of Balmeisporites. They did not mention species of either Ghoshispora or Styx in that report, but they did assign some of their Canadian specimens to Balmeisporites bellus Kondinskaya, a species originally described from the Upper Cretaceous and lower Paleocene of Siberia.

Shortly thereafter, Srivastava (1971) decided that Norton and Hall's species Styx minor from Montana was synonymous with Balmeisporites bellus from Siberia, but that the species did not belong in the genus Balmeisporites. He therefore reassigned both Norton and Hall's and Kondinskaya's specimens to a new nomenclatural combination, Styx bella (Kondinskaya) Srivastava. He noted that the size range within this species was great, the diameter of the spores ranging from 50 to $200 \mu \mathrm{m}$ not including acrolamellae. Bergad (1973) analyzed the taxonomic and nomenclatural problems associated with spores of this morphology and concluded that Styx minor Norton and Hall and Styx bella of Srivastava were distinct from Balmeisporites bellus Kondinskaya and that Styx minor was instead synonymous with $B$. longirimosus Kondinskaya, another Siberian species. Bergad also suggested that Srivastava's genus Ghoshispora was based on a poorly preserved specimen of Balmeisporites similar to B. longirimosus, implying synonymy of Balmeisporites and Ghoshispora.

Despite the confusion that abounded over the correct name for these distinctive spores in the early 1970's, Leffingwell (1970) assigned specimens that he found in the basal part of the Tullock Member and in the Lance Formation in Wyoming (which are conspecific with ours from the Tullock) to Srivastava's genus Ghoshispora, and B.D. Tschudy (1973) assigned similar specimens from the Campanian of Montana to Ghoshispora.

Most recently, Srivastava (1978) redescribed and emended Ghoshispora, placing emphasis on the acrolamellae. He also stated that it is indeed a megaspore in the botanical sense, despite its being less than $200 \mu \mathrm{m}$ in diameter (the arbitrary minimum size of megaspores in the morphologic sense). He reversed his earlier position on the status of the genus Styx and asserted that it is synonymous with Ghoshispora and reasserted that Balmeisporites is a separate genus, despite Bergad's (1973) opinion to the contrary. If indeed Balmeisporites is a separate genus, the name Ghoshispora has priority for specimens like ours from the Powder River Basin. However, it still is not entirely clear that the specimens from Montana and Wyoming are 
conspecific with the Siberian species, G. bella. Perhaps the name for the Tullock specimens should be Ghoshispora minor, which would be a new combination. In the absence of Siberian specimens with which to compare with ours, we defer to Srivastava's latest decision and apply the name Ghoshispora bella to our specimens from the Tullock Member.

In our study, Ghoshispora bella was found in four samples from the lower part of the Tullock Member in the southern part of the basin. As mentioned above, Leffingwell (1971) found specimens, which he also assigned to Ghoshispora, in the Tullock as well as in the Lance. Our specimens were present in assemblages that include freshwater algal cysts. They were unusually common in sample D7100-C, carbonaceous shale from locality Lance Creek 1, which also yielded massulae of the heterosporous aquatic fern Azolla cretacea.

\section{Gleicheniidites sp. cf. Gleichenia triangula Stanley}

Plate 3, figures 6-8

Spores assigned to Gleicheniidites sp. in this study are trilete, triangular with narrowly rounded apices, psilate, and have well-developed thickenings of the sporoderm in the interapical areas; they are about $25 \mu \mathrm{m}$ in diameter. They fall within the circumscription of the genus Gleicheniidites. They closely resemble specimens described by Stanley (1965) as Gleichenia triangula; however, Stanley's species, which he assigned to a modern genus, was recorded from a single sample from the Cretaceous Hell Creek Formation and not at all from the Fort Union Formation. Specimens we compare with his were present in two-thirds of the Tullock samples we studied in detail, in all rock types. Leffingwell (1970) also reported Gleicheniidites from the Fort Union but did not describe or illustrate his specimens. Norton and Hall (1969) apparently referred similar specimens to the much too broadly circumscribed species $G$. senonicus.

\section{Osmundacidites sp.}

Plate 2, figure 11

Osmundacidites encompasses circular trilete spores that have granulate sculpture and is thus distinguished from Baculatisporites and Foraminisporis, both of which are characterized by more robust baculate and clavate sculpture. Spores referable to Osmundacidites were first reported from the Tullock Member by Leffingwell (1970).

Our specimens from the Tullock Member were present in low relative abundance in eight samples representing all rock types studied. They tended to be more common in coal and carbonaceous shale than elsewhere.

\section{Stereisporites spp.}

Plate 3, figures 12-15; plate 4, figures 1-4

Stereisporites includes spores referable to the bryophyte family Sphagnaceae-sphagnum moss. All are trilete and have thickened walls, especially at the equator. Among Tullock specimens, some are simple in form but others exhibit various sculpture, especially thickenings of the sporoderm at the distal pole, triradiate proximal thickenings, proximal interradial thickenings, and small, evenly distributed verrucae. Several species could be distinguished on the basis of these variations, as was done for European species by Krutzsch (1963). No species-level distinctions were attempted for Tullock specimens because the paleoecologic significance of these spores, as indicators of bog environments, is the same at the genus level.

Stanley (1965) reported three species of these spores, which he assigned to the modern genus Sphagnum. They include Sphagnum antiquasporites, the species described by Wilson and Wester (1946) from the Fort Union Formation. They also include two other species that are fundamentally the same at the genus level and belong in Stereisporites, but that Stanley assigned to Cingulatisporites and suggested were spores of Selaginellaceae, a suggestion unsubstantiated on the basis of morphology. Norton and Hall (1969), following Stanley (1965), listed species of both genera. Leffingwell (1970), recognizing the morphologic uniformity of all these species at the level of genus, listed them as the "Stereisporites-Cingulatisporites complex."

In this study, spores of Stereisporites spp. were found in 11 samples. They were especially common in some coal samples but were nowhere dominant; they were not restricted in occurrence by lithology. From these observations it is apparent that plants that produced spores of Stereisporites spp. were present in many wetland depositional environments of the Tullock, but that no Tullock coal developed from a sphagnum bog.

\section{Toroisporis major (Pflug) Stanley}

Plate 3, figures 9-11

Spores identified as Toroisporis major in this study closely resemble those described by Stanley (1965). The characteristic tori on the proximal surface are not obvious on all specimens, and, except for those features, these spores fall within the circumscription of Deltoidospora. They differ from Cyathidites diaphana in having straight to convex sides and thicker exines.

Toroisporis major was present in all rock types sampled in this study but in fewer than half the samples. It shows no clear pattern of association with a particular sedimentary facies or plant community. 
Zlivisporis novomexicanum (Anderson) Leffingwell

Plate 4, figures 5-13

Zlivisporis novomexicanum was described by Anderson (1960) from the uppermost Cretaceous and lowermost Tertiary of New Mexico. Anderson referred the species to the modern club-moss genus Lycopodium. The botanical affinity of these spores is uncertain, but they do not closely resemble spores of Lycopodium. They have greater resemblance to certain bryophyte spores illustrated by Erdtman (1957). Leffingwell (1970) transferred the species to Zlivisporis. Specimens from the Tullock Member that we assign to Zlivisporis novomexicanum exhibit considerable variation in morphology in detail, especially in the coarseness of the distal reticulum and presence or absence of proximal sculpture, and some are only questionably assigned to this species (plate 4, figs. 7, 8, 13). B. D. Tschudy (1973) assigned specimens of similar form and exhibiting a comparable range of morphologic detail to individual species of the genus Seductisporis. Zlivisporis differs from Seductisporis in having a more prominent trilete mark, a distinction that is unclear in some specimens.

Zlivisporis novomexicanum was present in only five Tullock samples studied in detail. It was not present in coal samples and thus presumably was not produced by plants that inhabited peat-forming mires.

\section{Gymnosperm Pollen}

\section{Araucariacites sp.}

Plate 5, figure 1

Pollen grains assigned to Araucariacites sp. in this study are spheroidal and inaperturate and have thin, scabrate to finely granulate exines. They presumably were produced by araucariaceous conifers, although the morphology of these pollen grains is not definitive. Brown (1962) reported distinctive araucarian leaves and cones from the lower part of the Fort Union Formation that tend to substantiate the identification of the pollen.

Araucariacites sp. is a rare component of the Tullock palynoflora. It was recorded in only three samples, none of which were coals.

\section{Corollina sp.}

Plate 5, figures 2,3

A species of the predominantly pre-Tertiary genus Corollina $(=$ Classopollis $)$ is present in the Tullock palynoflora. The plants that produced this morphologically distinctive type of pollen were coniferopsids of the extinct order Voltziales, family Hirmerelliaceae (=Cheiro- lepidaceae), whose megafossil record extends from the Pennsylvanian to the Cretaceous (Taylor, 1981). The genus has not been reported previously from the Tullock Member, but D.T. Pocknall and D.J. Nichols (unpublished data) found similar, probably conspecific, specimens to have rare but consistent occurrence in the Tongue River Member of the Fort Union Formation. They considered their specimens to be indigenous and not reworked from older rocks. Frederiksen (1980) reviewed records of Corollina (under the name Classopollis) from the Atlantic and Gulf Coastal plains and concluded that the genus ranges at least into the Midwayan (lower Paleocene) in that region.

In this study, we recorded Corollina sp. in rare abundance in one-third of the samples, in all rock types. These records of Corollina pollen from the Powder River Basin are evidence that the Voltziales survived into the early Tertiary in the Rocky Mountain region.

\section{Cycadopites scabratus Stanley}

Plate 5, figure 4

Cycadopites scabratus is monosulcate, with the sulcus tending to be open at the extremities, and has a scabrate exine. Specimens are similar in general appearance to pollen of Arecipites and may be confused with them.

Cycadopites scabratus was first described from the Cannonball Member of the Fort Union Formation in South Dakota by Stanley (1965) and was recorded from the Tullock Member in Montana by Norton and Hall (1969). Leffingwell (1970) reported Cycadopites follicularis but not C. scabratus from the Tullock in Wyoming. The former species differs from C. scabratus in being larger and having a psilate exine. Cycadopites scabratus was present in about half of the Tullock samples we studied in detail, in all rock types.

\section{Pityosporiteș spp.}

Plate 5, figures 7-11; plate 6, figures 1,2

In this study, fossil bisaccate conifer pollen resembling that produced by extant species of pine and spruce is assigned to the form genus Pityosporites. The breadth of the sacci of these specimens is about equal to the depth of the corpus (terminology of Erdtman, 1957). More than one and perhaps several species are represented and might be distinguished by size or other criteria, but no attempt was made to distinguish species in this study. Stanley (1965) assigned pollen of this morphology to the modern genera Picea and Pinus. Norton and Hall (1969) assigned them to the form genera Abietineaepollenites, Pinuspollenites, and Cedripites. Leffingwell (1970) assigned them to his "Podocarpaceae-Pinaceae complex." 
These fossils are among the most commonly occurring in the Tullock palynoflora in that they were found in all but three samples studied, although their relative abundance in individual assemblages is not great. They were most abundant in sample D7299-R, a carbonaceous shale from the Sussex locality, in which they amounted to about 40 percent of the assemblage. In most assemblages where they were present, they amounted to only a few percent. Modern conifers of the pine family produce prodigious numbers of pollen grains that tend to dominate palynological assemblages collected from the vicinity of the trees. On the basis of their relatively low abundance but consistent occurrence, Pityosporites spp. from the Tullock are interpreted to represent trees growing some distance from the depositional area, probably in highlands to the west. This interpretation is consistent with the observation of Brown (1962) that no foliage, seeds, or wood attributable to pine is known from Paleocene strata in the Rocky Mountain region. We conclude that because of its common occurrence in Tullock samples, pollen of Pityosporites spp. is characteristic of the Tullock palynoflora, even though the plants that produced this pollen were rare or absent in Tullock depositional environments.

\section{Podocarpidites maximus (Stanley) Norton \& Hall}

Plate 6, figure 3

Bisaccate pollen in which the saccus breadth greatly exceeds corpus depth are assigned to Podocarpidites. Tullock specimens are virtually identical with those described by Stanley (1965) from the Cannonball Member of the Fort Union Formation as Podocarpus maximus. Norton and Hall (1969) transferred Stanley's species to Podocarpidites, although they accepted his suggestion that the fossils represented a species of the modern genus Podocarpus. Leffingwell (1970) included pollen of this morphology in his "Podocarpaceae-Pinaceae complex." On the basis of critical details of pollen morphology, D.T. Pocknall and D.J. Nichols (unpublished data) cast serious doubt on the inference that bisaccate pollen having large sacci are referable to Podocarpus, living species of which are native to the Southern Hemisphere. Brown (1962) reported no megafossils of Podocarpus from the Paleocene of the Rocky Mountain region. We regard Podocarpidites as a form genus having no implication of botanical affinity, and the species $P$. maximus as a fossil pinaceous species.

Podocarpidites maximus was present as a relatively rare component of assemblages in seven Tullock samples. It was present in all rock types studied. Plants producing this pollen probably inhabited upland areas to the west of the Tullock depositional area.
Taxodiaceaepollenites hiatus (Potonié) Kremp

Plate 5, figures 5, 6

Pollen identified as Taxodiaceaepollenites hiatus includes specimens that are spheroidal and inaperturate and have scabrate exines; they generally are found split open and may exhibit poorly developed papillas. Pollen of this general morphology is characteristic of three closely related modern families of coniferous gymnosperms, the Taxodiaceae, Cupressaceae, and Taxaceae. Stanley (1965) tentatively assigned pollen of this morphology to Thuja, a modern genus of the Cupressaceae; such an assignment is unjustified in view of the lack of definitive morphologic characters. Norton and Hall (1970) applied the name Taxodiaceaepollenites hiatus but suggested affinity only with the Taxodiaceae. Leffingwell (1970) only referred this type of pollen to his "Taxodiaceae-Cupressaceae complex." Pocknall and Flores (1987), in discussing the role of this pollen in fossil plant communities of the Tongue River Member of the Fort Union Formation, concluded that it is related to the modern genus Glyptostrobus (Taxodiaceae) but recognized that pollen of Glyptostrobus may be indistinguishable from that of the modern genus Taxodium (Taxodiaceae).

At present, both Glyptostrobus and Taxodium are inhabitants of swamps, and the abundance of this kind of pollen in Paleocene coals in the Rocky Mountain region suggests that fossil species of the Taxodiaceae were major contributors to the plant matter that formed the coals. This is true for coals of the Tongue River Member, but Taxodiaceaepollenites hiatus is relatively rare in Tullock coals; it follows that the Taxodiaceae contributed little to accumulation of coals of the Tullock Member. This species is more common in our samples of the Lebo Member of the Fort Union than in the Tullock. Relative abundance data of Leffingwell $(1970$, pl. 3) show that taxodiaceous pollen is rare in the lower part of the Tullock Member, more abundant upward toward the Lebo, and dominant in the Tongue River Member. In this study, $T$. hiatus pollen was present in little more than half the samples and, in most cases, is a rare component of assemblages. It was somewhat less common in coals than in clastic rocks.

\section{Angiosperm Pollen-Monosulcate}

\section{Arecipites tenuiexinous Leffingwell}

Plate 6, figures 4-7

Arecipites tenuiexinous includes monosulcate pollen having a thin exine and finely reticulate sculpture. As in all species of Arecipites, the sulcus extends to the ends of the grain and is tapered at its extremities. As originally described by Leffingwell (1970), the lumina of the reticulum are about $0.5 \mu \mathrm{m}$ in diameter. Some specimens we 
assign to this species have a finer reticulum and tend toward a sculpture pattern better described as microfoveolate. Leffingwell measured 10 specimens and determined their length to be from 25 to $30 \mu \mathrm{m}$; the size range of 10 of our specimens is $30-33 \mu \mathrm{m}$. Arecipites tenuiexinous differs from Arecipites reticulatus Anderson only in size; Anderson's species, which is from the Upper Cretaceous and lower Tertiary of New Mexico, was described as having a fine reticulum (lumina $0.5 \mu \mathrm{m}$ in diameter) and ranging from 18 to $23 \mu \mathrm{m}$ in length. The pollen morphology of these species indicates that they were produced by palms. Brown (1962) attributed leaves from the lower part of the Fort Union Formation to species of the modern palm genus Sabal.

Arecipites tenuiexinous originally was described from the Powder River Basin by Leffingwell (1970). It is present in both the Lance Formation and the Tullock Member, although Leffingwell did not report it from the upper part of the Tullock. It was absent from our samples of the upper part of the Tullock at the Cow Creek locality, but it was present in samples from the lower part of the Lebo Member collected about $2 \mathrm{~km}$ to the southwest. It is one of the most commonly occurring species in the Tullock palynoflora and was present in more than 80 percent of the samples we analyzed in detail.

\section{Liliacidites leei Anderson}

Plate 6, figure 8

Liliacidites leei is monosulcate and reticulate, but, as is characteristic of the genus Liliacidites, the reticulum varies in coarseness and generally is finer toward the ends of the grain. The diameter of lumina is from 1 to $1.5 \mu \mathrm{m}$. The coarser and variable sculpture serves to distinguish this species from Arecipites tenuiexinous. Liliacidites leei differs from other species of the genus described by Leffingwell (1970) from the Upper Cretaceous of the Powder River Basin in having low, simplibaculate muri. Botanical affinity is with the Monocotyledonae and probably with the Liliaceae.

This species was originally described from uppermost Cretaceous and lower Tertiary rocks in New Mexico (Anderson, 1960) and has not been reported previously in the Powder River Basin. We recorded it only in the basal part of Tullock Member at the Sussex locality.

\section{Angiosperm Pollen-Tricolpate}

\section{Discoidites parvistriatus (Norton) n. comb.}

Plate 6. figures 9-11

Basionym: Tricolpites parvistriatus Norton in Norton and Hall, 1967, p. 105, pl. 1, fig. E.

Norton (in Norton and Hall, 1967) described "Tricolpites" parvistriatus as being circular in polar view, having very short colpi, and having an ektexine composed of closely spaced baculae that present a vague striate sculpture. The striate pattern of sculpture he referred to is not evident in the holotype specimen (Norton and Hall, 1967, pl. 1, fig. E, reillustrated in Norton and Hall, 1969, pl. 7, fig. 2) nor in specimens we found in our samples from the Powder River Basin. More important, the sculpture of none of these specimens is reticulate; thus the assignment of this species to the genus Tricolpites is inappropriate. The apertures, which extend no more than one-third of the distance toward the poles, are best described as brevicolpate, and brevicolpate apertures are not characteristic of Tricolpites. Thus, this species requires redescription and reassignment.

Redescription.-Triaperturate pollen, brevicolpate; colpi simple and lacking margines, equatorial, extending about one-third of distance to poles; amb circular to broadly rounded interangular; form oblate to peroblate, $20-25 \mu \mathrm{m}$ in diameter; exine tectate, columellate, 1-1.5 $\mu \mathrm{m}$ thick, ektexine thicker than endexine, endexine tending to thicken at the colpi; columellae generally evenly arranged, not tending to form reticulate or striate patterns beneath the tectum; tectum nonperforate, ends of baculae protruding through tectum to form supratectal scabrate to granulate sculpture.

The genus Discoidites was proposed by Muller (1968). It encompasses tricolpate, disc-shaped pollen having short colpi and tectate exines in which the tops of the columellae project through the tectum to form a finely verrucate pattern. This genus differs from Tiliaepollenites Potonié \& Venitz in having colpate apertures and in lacking vestibulate pores. Discoidites borneensis Muller, type species of the genus, shows darkened (presumably thickened) areas of exine surrounding the apertures, but these features (costae pori?) are not mentioned in the generic description and may be considered species-level characters. Discoidites parvistriatus differs from $D$. borneensis in smaller size, narrower colpi, endexinal thickenings near the apertures that are only weakly developed to absent, and finer sculpture. Muller (1968) suggested tiliaceous affinity for $D$. borneensis; we regard Discoidites as a form genus and do not necessarily imply such botanical affinity for $D$. parvistriatus. Two aspects of the morphology of $D$. parvistriatus, however, are suggestive of pollen of modern Tiliaceae: exine structure (including a weak tendency to development of costae pori) and tendency to have an interangular amb. Possibly this Late Cretaceous and early Tertiary species is an early ancestral member of the lineage of the Tiliaceae.

Norton and Hall $(1967,1969)$ reported "Tricolpites" parvistriatus as being restricted to the Hell Creek Formation. The species is more common in the uppermost Cretaceous (Hell Creek and Lance Formations and equivalents) than in the lowermost Tertiary in the region, but it is present in the lower part of the Fort Union Formation and equivalents (Leffingwell, 1970; Jerzykiewicz and Sweet, 1986; Lerbekmo and others, 1987; 
Johnson and others, 1989). In our study, we found Discoidites parvistriatus in samples of the lower part of the Tullock Member from a few localities in Montana and Wyoming. It was present but rare in Tullock coal, carbonaceous shale, and mudstone.

\section{Fraxinoipollenites variabilis Stanley}

Plate 6, figures 12-16

The taxonomic history of this species is confused because Stanley (1965) apparently included more than one morphotype when he described it. Specimens assigned to this species by Leffingwell (1970) resemble Stanley's paratypes but depart somewhat from the morphology of the holotype. Specimens from the Tullock Member that we assign to Fraxinoipollenites variabilis are finely reticulate and have long colpi that closely approach the poles. The long colpi serve to distinguish this species from other reticulate tricolpate pollen. Specimens of $F$. variabilis were present in low numbers in all rock types sampled. They were unusually common in sample D7137-I, mudstone from the basal Tullock at the Lance Creek locality.

\section{Quercoidites spissus Leffingwell}

Plate 6, figures 17,18

Quercoidites spissus includes tricolpate pollen having granulate sculpture. Leffingwell (1970), who described the species, reported it from both the Lance and Fort Union Formations in the Powder River Basin. In our samples, specimens were found only in Tullock coal samples from the Montana part of the basin.

\section{Retitrescolpites anguloluminosus (Anderson) Frederiksen}

Plate 6, figures 19-21

Retitrescolpites anguloluminosus is distinguished from other species of reticulate tricolpate pollen in the Tullock palynoflora by its coarsely reticulate sculpture. The lumina of the reticulum are $2-3 \mu \mathrm{m}$ in diameter. It was originally described as a species of the genus Tricolpites by Anderson (1960), but Frederiksen (1979) transferred it to Retitrescolpites, which encompasses tricolpate pollen having coarsely reticulate rather than finely reticulate tricolpate sculpture. Norton and Hall (1969) and Leffingwell (1970) considered coarsely reticulate tricolpate pollen described by Stanley (1965) as Tricolpites bathyreticulatus to be a separate species, but we consider Stanley's species to be synonymous with $R$. anguloluminosus.

This species was present in about one-third of our Tullock samples from Wyoming localities, but we did not observe it in any sample from Montana. Norton and Hall's (1969) records of this species from the Tullock and Lebo in
Montana indicate, however, that it is not geographically restricted. It was present in coal and all fine-grained clastic rock types sampled in the southern part of the Powder River Basin. The previously published records of occurrence of this species cited here are all from lower Tertiary rocks, but the species may be present also in the uppermost Cretaceous of the region and not restricted to the Tullock and equivalents.

\section{Rousea spp.}

Plate 7, figures 1,2

Rousea includes reticulate tricolpate pollen in which the reticulum varies in coarseness, becoming finer toward the poles and the margins of the colpi. Individual specimens from 25 to $45 \mu \mathrm{m}$ in size were recorded in four samples in this study. These species, grouped here in a single genuslevel taxon, are extremely rare components of the Tullock palynoflora.

\section{Striatopollis tectatus Leffingwell}

Plate 7, figures 3,4

Striatopollis tectatus is distinctive in having finely striate sculpture. Striate tricolpate pollen is produced by some modern species of the family Aceraceae (maples), suggesting this affinity for the Tullock fossils. Striatopollis tectatus was present in about half of our samples. This species is present also in underlying Cretaceous rocks in the Powder River Basin.

\section{Tricolpites hians Stanley}

Plate 7, figures 5-7

In this study, small (about $25 \mu \mathrm{m}$ in greatest dimension), finely reticulate (lumina $1 \mu \mathrm{m}$ or less in diameter), tricolpate pollen was assigned to Tricolpites hians. Included are specimens that Leffingwell (1970) assigned to $T$. parvus Stanley. Specimens assigned to Tricolpites hians differ from those assigned here to the broader taxon Tricolpites spp. in having a very fine reticulum, although the distinction is difficult to make in some specimens. All specimens assigned to the genus Tricolpites in this study differ from those assigned to Retitrescolpites anguloluminosus in having much finer sculpture. Species assigned to Tricolpites differ from species of the genus Rousea in having evenly developed sculpture. Fraxinoipollenites variabilis has fine, evenly developed sculpture but longer colpi.

Pollen referable to either Tricolpites hians or Tricolpites spp. is present in almost all Tullock samples examined in detail in our study. Similar or identical specimens are known to occur commonly in Upper Cretaceous and lower Tertiary rocks throughout the Rocky Mountain region. The botanical affinity of $T$. hians may be with the Platanaceae 
(sycamore family), but the morphology of the pollen is not distinctive enough for this to be certain.

\section{Tricolpites spp.}

Plate 7, figures $8-12$

Specimens assigned to Tricolpites spp. in this study probably include more than one species. All are tricolpate and reticulate and have a fine to medium reticulum (lumina about 1-2 $\mu \mathrm{m}$ in diameter). Some are quite close to Tricolpites hians in morphology, but they form an apparent morphologic continuum with specimens that are more coarsely sculptured than $T$. hians. The specimens illustrated here exhibit the range in morphology.

Pollen referable to Tricolpites spp. is present in almost all Tullock samples. Their botanical affinity could be with the Platanaceae (sycamore family), but this is uncertain because the modern families Haloragaceae, Hamamelidaceae, Ranunculaceae, Salicaceae, and Trochodendraceae also include species that produce pollen having similar morphology.

\section{Angiosperm Pollen-Tricolporate}

\section{Brevicolporites colpella Anderson}

Plate 7, figures 13,14

Brevicolporites colpella includes circular, oblate, brevitricolporate pollen having broad arci between apertures and scabrate exines. The species was originally described by Anderson (1960) from the lowermost Paleocene in the San Juan Basin of New Mexico. Subsequently it was reported by Jerzykiewicz and Sweet (1986) from the lower Paleocene of Alberta. It has not been reported previously from the Powder River Basin. It is a rare component of the Tullock palynoflora, but in this study it was recorded in coal, shale, and mudstone samples from the lower and middle parts of the Tullock Member.

\section{Kurtzipites circularis (Norton) Srivastava}

Plate 7 , figures $15-17$

Kurtzipites circularis is tricolporate (brevicolpate) and has apertures located in distinctive projections at the equator. This species was originally described by Norton (in Norton and Hall, 1969) as a species of the genus Momipites, but clearly it has no relationship with or close resemblance to that genus. Norton's specimens were from the Hell Creek Formation and lower Fort Union equivalent in the Hell Creek area of Montana. Leffingwell (1970) described specimens that are identical with Norton's as a new species, $K$. simplex. Leffingwell's specimens were from the Lance Formation and Tullock Member of the Fort Union in the
Lance Creek area of Wyoming. All these specimens are conspecific, and Kurtzipites circularis is their correct name. Srivastava (1981) transferred Norton's species to Kurtzipites and placed Leffingwell's species in synonymy with it. Kurtzipites circularis differs from $K$. trispissatus Anderson in lacking endexinal thickenings at the apertures.

Leffingwell (1970) found specimens of Kurtzipites spp. to occur no higher stratigraphically than the lower part of the Tullock Member, but we found $K$. circularis to be the dominant species in the upper part of the Tullock at the Cow Creek locality. Kurtzipites circularis was present in about two-thirds of the samples we examined in detail in our study.

\section{Kurtzipites trispissatus Anderson}

Plate 7, figures 18,19

Kurtzipites trispissatus was originally described by Anderson (1960) from the uppermost Cretaceous of New Mexico. He regarded it as triporate, but Leffingwell (1970) correctly redescribed it as tricolporate. Kurtzipites trispissatus closely resembles $K$. circularis and differs only in having pairs of prominent endexinal thickenings at the apertures. Specimens are most commonly preserved in polar view. As noted by Srivastava (1981), Stanley (1965) described specimens of $K$. trispissatus preserved in equatorial view as Aenigmapollis polyformis; Srivastava placed Stanley's species in synonymy with $K$. trispissatus.

Stanley (1965) neither described nor illustrated any other specimens that resemble species of Kurtzipites in his samples from South Dakota, although they are common in uppermost Cretaceous and lowermost Tertiary rocks in western North America. Norton and Hall (1969) reported $K$. trispissatus from the Hell Creek Formation in Montana, and Leffingwell (1970) reported it from the Lance Formation and the Tullock Member of the Fort Union in Wyoming. We found it to be present in all rock types, although not in all samples, in the lower and middle parts of the Tullock. Norton (in Norton and Hall, 1969) described another closely related species of Kurtzipites from the Hell Creek Formation, $K$. annulatus, in , which the endexinal thickenings at each aperture form a ring instead of being in pairs. This same species was reported by Leffingwell (1970) from the Lance Formation and Tullock Member of the Fort Union as Kurtzipites sp. We did not distinguish $K$. annulatus from $K$. trispissatus in our samples, although some specimens we identified as the latter species could prove on closer inspection to be the former.

As mentioned, previous records from the Powder River Basin indicate the upper limit of the range of Kurtzipites spp. to be within the Tullock Member. In our study we recorded $K$. circularis throughout the Tullock, including the uppermost part of the member in the southern part of the basin, and we recorded $K$. trispissatus in many samples from the lower and middle parts of the member in 
both Wyoming and Montana. We did not find any species of Kurtzipites in the Lebo Member. On the basis of this pattern of stratigraphic distribution, species of Kurtzipites can be considered as characteristic components of the Tullock palynoflora. On the basis of reports cited in the preceding discussions, species of this genus are present in lower Paleocene rocks from New Mexico to Alberta, Canada, and they should prove useful in regional correlation.

\section{Nyssapollenites spp.}

Plate 7, figures 20, 21

In this report, all triangular, oblate, tricolporate pollen having reduced sculpture (including finely reticulate and granulate) was assigned to the taxon Nyssapollenites spp. Specimens conforming with this general description were recorded in about one-third of the samples studied in detail, in coal and fine-grained clastic rock types. No biostratigraphic or paleoenvironmental significance is attributed to this heterogeneous group.

\section{Rhoipites spp.}

Plate 7, figures 22-24

We assigned all prolate, finely reticulate, tricolporate pollen from the Tullock Member to the taxon Rhoipites spp. Norton and Hall (1969) assigned similar specimens to several different species of the genus Tricolporopollenites. Our specimens are from 20 to $40 \mu \mathrm{m}$ in polar diameter. They were recorded in about one-fourth of the samples studied in detail, in coal, carbonaceous shale, and shale. No biostratigraphic or paleoenvironmental significance is attributed to this heterogeneous group.

\section{Tilia vescipites Wodehouse}

Plate 8, figures 1,2

Tilia vescipites includes oblate, brevicolporate pollen having very finely reticulate sculpture. Endexinal thickenings characteristic of modern pollen of the genus Tilia are present but not well developed, and it is difficult to ascertain if the pores are truly vestibulate. This species may represent an early ancestor in the lineage of the Tiliaceae (basswood family), but assignment of the fossil species to the modern genus probably is not supported by detailed consideration of pollen morphology.

In this study a single specimen was recorded in carbonaceous shale from the Minnehaha Creek locality in Montana. Despite its rarity, it is noteworthy because it may be the earliest record of the tiliaceous lineage (but see also discussion of Discoidites parvistriatus). Nichols and Ott (1978) recorded Tilia vescipites from the middle Paleocene in the Wind River basin. The species was originally described by Wodehouse (1933) from the lower Eocene.
Angiosperm Pollen-Syncolporate

Cupanieidites inaequalis Leffingwell

Plate 8 , figures 5,6

Cupanieidites inaequalis includes syncolporate pollen having polar islands at one or both poles and intectate, very finely reticulate exines. It differs from Syncolporites minimus in larger size and in having reticulate rather than granulate sculpture. The species was originally described by Leffingwell (1970) from the Lance and Fort Union Formations in the Powder River Basin. Similar specimens from the uppermost Cretaceous and lower Tertiary in New Mexico were assigned to Cupanieidites aff. $C$. major by Anderson (1960), and others from the Hell Creek and Tullock in Montana were assigned to $C$. major by Norton and Hall (1969). Leffingwell (1970) noted that $C$. major is larger and has more distinct pores than does $C$. inaequalis.

In our study $C$. inaequalis was recorded in about one-third of the Tullock Member samples studied in detail. It was found in coal and all fine-grained clastic rock types.

\section{Syncolporites minimus Leffingwell}

Plate 8, figures 3, 4

Syncolporites minimus includes small, granulate, syncolporate pollen. The species was originally described by Leffingwell (1970) from the Lance and Fort Union Formations in the Powder River Basin. It was subsequently reported by Jerzykiewicz and Sweet (1986) from the uppermost Cretaceous and lowermost Tertiary Coalspur Formation in Alberta and by Johnson and others (1989) from the lowermost Tertiary Ludlow Formation of the Fort Union Group in North Dakota.

Syncolporites minimus (along with Triporopollenites plektosus) tends to dominate some assemblages just above the $\mathrm{K}-\mathrm{T}$ boundary in the Coalspur Formation (Jerzykiewicz and Sweet, 1986). It is also abundant in samples just above the $\mathrm{K}-\mathrm{T}$ boundary in North Dakota (Johnson and others, 1989). In the Powder River Basin this species was present in about one-third of all samples from the Tullock Member examined in detail but never in high relative abundance. It was recorded in coal and all fine-grained clastic rock types.

\section{Angiosperm Pollen-Monoporate}

\section{Pandaniidites typicus (Norton) Sweet}

Plate 8 , figures $7-9$

Pandaniidites typicus is spheroidal to elliptical, monoporate, and echinate; the pore is annulate in most specimens. The exine is thin, and most specimens are 
randomly folded. Although the botanical affinity of this species has been questioned by Sweet (1986), who suggested it might be with the Lemnaceae (duckweed family), we follow Simpson (1961), Elsik (1968), Norton and Hall (1969), Leffingwell (1970), Muller (1981), and Jarzen (1983), who referred fossil pollen of this morphology to the Pandanaceae (pandans or screw-pines). Muller (1981) suggested that the specimens described by Elsik (1968) and Leffingwell (1970) may represent an extinct group of the Pandanaceae.

Pollen of this morphology was first described by Simpson (1961) from lower Tertiary deposits in Scotland, the species Pandaniidites shiabensis (Simpson) Sweet. Elsik (1968) described closely similar specimens from the Paleocene of Texas. He named a new species, P. texus, which he distinguished from Simpson's species by placing emphasis on the pore being annulate. Elsik also attempted to transfer Simpson's species from the modern genus Pandanus to Pandaniidites, but he failed to clearly identify the basionym, as required by the International Code of Botanical Nomenclature, and his new combination is invalid; Sweet (1986) later made that transfer validly. Without reference to the previously described forms, Norton (in Norton and Hall, 1969) described closely similar specimens from the uppermost Cretaceous and lower Paleocene of Montana as a new genus and species, Spinamonoporites typicus. Leffingwell (1970) described specimens from the Lance and Fort Union Formations in the Powder River Basin as Pandaniidites radicus. He stated that thinner exine distinguished $P$. radicus from $P$. texus and $P$. shiabensis; he did not compare his specimens with Norton's. Sweet (1986) noted that differences of opinion had been expressed by the previous authors about presence or degree of development of an annulus surrounding the pore, wall thickness, and exine stratification, but that all of these authors had described closely similar if not conspecific taxa. He pointed out that Norton had provided the broadest circumscription, which would encompass all previously described species, and transferred Norton's species to the genus Pandaniidites. We follow Sweet's taxonomy and nomenclature, although not his suggested botanical affinity, for our Tullock specimens.

Pandaniidites typicus was present in about half of our samples from the Tullock Member and was found in all rock types sampled. It was especially common in a sample of carbonaceous shale from the Buckskin Butte locality in Montana and in a sample of mudstone from the Lance Creek 1 locality in Wyoming.

\section{Sparganiaceaepollenites sp.}

\section{cf. Sparganium globites Wilson \& Webster}

Plate 8, figures 10-12

Specimens from the Tullock Member that we assign to Sparganiaceaepollenites sp. cf. Sparganium globites are spheroidal, monoporate, and reticulate. They resemble specimens from the Fort Union Formation in western Montana described by Wilson and Webster (1946) as Sparganium globites, except that the pore is much smaller in diameter. The botanical affinity of these specimens probably is with the Sparganiaceae (bur-reed family) or Typhaceae (cattail family). Modern species of both families are marsh plants.

Specimens resembling Sparganiaceaepollenites sp. cf. Sparganium globites have not been reported previously from the Powder River Basin. They are rare in the Tullock Member and were found in only three samples: carbonaceous shale from the lower part of the Tullock at the Buckskin Butte and Minnehaha Creek localities in Montana, and shale from the upper part of the Tullock at the Cow Creek locality in Wyoming.

\section{Angiosperm Pollen-Triporate}

\section{Momipites inaequalis Anderson}

Plate 8, figure 13

Momipites inaequalis includes specimens of the distinctive and biostratigraphically important genus Momipites that lack modifications of exine structure at one pole. Like all species of the genus, $M$. inaequalis has atriate pores and a fine sculpture of widely spaced scabrae. Some specimens of this species are slightly unequally triangular.

This species was originally described by Anderson (1960) from the lowermost Paleocene in the San Juan Basin, New Mexico, and it is also present in the lowermost Paleocene in the Raton Basin, New Mexico (Fleming, 1990). Stanley (1965) described similar, probably at least in part conspecific, pollen from the lower Paleocene of South Dakota as Engelhardtia microfoveolata, but he misinterpreted the fine sculpture pattern as microfoveolate. Johnson and others (1989) reported $M$. inaequalis from the lowermost Paleocene in North Dakota. Norton and Hall (1969) stated that they found no specimens resembling Stanley's in their lower Paleocene material from eastern Montana. (They described two species they assigned to the genus Momipites, one or perhaps both of which belong in the genus Kurtzipites, which they apparently confused with Momipites, although the two genera have little in common morphologically.) Momipites inaequalis was reported previously in the Powder River Basin at the Sussex K-T boundary locality (Nichols and others, 1992). The botanical affinity of this species is with the Juglandaceae (walnut family).

Momipites inaequalis was present in about one-third of our samples of the Tullock Member, in coal and all fine-grained clastic rock types, although never in high relative abundance. It is present in the Tullock in Montana as well as in Wyoming but may be at the northern edge of its paleogeographic range in Montana. This species may be 
regarded as characteristic of the lowermost Paleocene, although it also is present rarely in the uppermost Cretaceous, just below the $\mathrm{K}-\mathrm{T}$ boundary (Johnson and others, 1989; Fleming, 1990; Nichols and others, 1992).

\section{Momipites leffingwellii Nichols \& Ott}

Plate 8 , figure 14

Momipites leffingwellii is one of the species of Momipites that are characterized by modifications of exine structure at one pole. In $M$. leffingwellii the modification is a ring-shaped thinning of the exine surrounding the distal pole. This species is additionally distinguished by straight to concave sides.

This species was originally described from the lowermost Paleocene of the Wind River Basin by Nichols and Ott (1978). Leffingwell (1970) described several more or less similar species from the Powder River Basin and placed them all in a new genus, Maceopolipollenites. Nichols (1973) placed that genus in synonymy with Momipites and transferred all of Leffingwell's species to Momipites. As noted by Nichols and Ott (1978), specimens previously reported from the Powder River Basin as Maceopolipollenites tenuipolus (Anderson) actually belong to Momipites leffingwellii. However, we also identified Anderson's species Momipites tenuipolus from the Tullock Member, so only some of the specimens reported by Leffingwell (1970) are referable to Momipites leffingwellii. The botanical affinity of this species is with the Juglandaceae (walnut family).

Momipites leffingwellii is rare in the Tullock Member. In this study we found it in only four samples, all of which were from the middle or upper parts of the unit at the southern end of the basin. It was notably abundant in one sample of carbonaceous claystone from the Leverett Butte locality. We also recorded it from the Lebo Member in stratigraphic control samples from Wyoming and Montana; it was absent from our control samples from the Lance and Hell Creek Formations.

\section{Momipites tenuipolus Anderson}

Plate 8 , figures 15,16

Momipites tenuipolus is similar to $M$. leffingwellii in having a circumpolar ring (or in some specimens, a circular spot) of thin exine at one pole, and it differs primarily in having convex sides. It differs from the characteristically middle Paleocene species $M$. anellus Nichols and Ott in being smaller and in having a less clearly developed circumpolar ring of thin exine and polar island of normally thickened exine. These distinctions are subtle but important to recognize because, as emphasized by Nichols and Ott (1978), they are the basis of the biostratigraphic utility of species of the genus Momipites in the Paleocene of western North America.
Momipites tenuipolus was originally described by Anderson (1960) from the lower Paleocene of New Mexico. As noted above, this species was previously reported from the Powder River Basin by Leffingwell (1970). The botanical affinity of this species is with the Juglandaceae (walnut family).

In our study, we found Momipites tenuipolus to be more common in the middle and upper parts of the Tullock Member than in the lower part, a pattern of distribution also recorded by Leffingwell $(1970, \mathrm{pl}$. 1). It was present in all rock types we sampled but was more common in clastic rocks than in coal. Leffingwell also recorded this species in the uppermost part of the Lance Formation; we did not observe it in our control samples from the Lance or Hell Creek Formations.

Momipites waltmanensis Nichols \& Ott

Plate 8, figure 17

Momipites walmanensis is another species of the genus that lacks modification of exine at the poles. It differs from $M$. inaequalis and $M$. wyomingensis in having concave sides.

Momipites waltmanensis was originally described from the Wind River Basin (Nichols and Ott, 1978). A specimen illustrated by Stanley (1965, pl. 45, figs. 8-10) as Engelhardtia microfoveolata may be referable to Momipites waltmanensis. Momipites waltmanensis was previously reported from the Tongue River Member in the Powder River Basin by Pocknall (1987). The botanical affinity of this species is with the Juglandaceae (walnut family).

In our Tullock samples Momipites waltmanensis was present only in the middle and upper parts of the member. Based on our stratigraphic control samples, it is present also in the Lebo Member but absent from the Lance and Hell Creek Formations in the Powder River Basin.

\section{Momipites wyomingensis Nichols \& Ott}

Plate 8, figure 18

Momipites wyomingensis has convex sides and lacks modification of the exine at the poles. It differs from $M$. inaequalis in larger size and in being perfectly symmetrical, with all sides of equal length.

Momipites wyomingensis was originally described from the Paleocene of the Wind River Basin by Nichols and Ott (1978) and was previously reported in the Powder River Basin by Pocknall (1987). The botanical affinity of this species is with the Juglandaceae (walnut family).

This species is rare in the Tullock Member in the Powder River Basin. It was present in only one of our samples from the middle part of the unit at the Leverett Butte locality. It was present also in our control samples from the Lebo Member. 


\section{Thomsonipollis magnificus (Pflug \& Thomson) Krutzsch}

Plate 8 , figure 19

Thomsonipollis magnificus is a distinctive triporate species sometimes classified with the Normapolles pollen, although the pores do not project beyond the broadly rounded triangular to circular amb, as the apertures do in most species of Normapolles pollen. Internally the pores are complexly structured in the manner of Normapolles pollen, and they are annulate. The sculpture is densely baculate.

Thomsonipollis magnificus is known from the lower Tertiary of the Gulf Coast of the United States and from Europe (Krutzsch, 1960), and it also is present in the uppermost Cretaceous in New Mexico (R.H. Tschudy, 1973). This species has not been reported from the Cretaceous in Wyoming or Montana and has not been reported previously from the Paleocene in the Powder River Basin. The botanical affinity of this species is unknown.

Thomsonipollis magnificus is rare in the Tullock Member in the Powder River Basin. It was present in only two samples, carbonaceous shales from the Dry Creek locality in Montana and the Leverett Butte locality in Wyoming. It was notably common in the sample from Leverett Butte.

\section{Triatriopollenites granulatus (Simpson) Leffingwell}

Plate 8 , figure 20

Triatriopollenites granulatus includes small grains that are almost circular in outline and have three atriate pores, without annuli, that appear as notches in the amb. The exine is thinned in three areas located between each of the pores and the polar area; in some specimens the normally thickened exine in the interapertural and polar areas appears as a triradiate structure.

This species was originally described as a species of the modern genus Engelhardia ("Engelhardtia") by Simpson (1961), although it has little in common morphologically with pollen of that genus. Leffingwell (1970) transferred Simpson's species to the form genus Triatriopollenites. Simpson's specimens were from the lower Paleocene of western Scotland. In the Powder River Basin this species was reported previously by Leffingwell (1970) and Pocknall (1987). The botanical affinity of $T$. granulatus is unknown, but it is unlikely to be with the Juglandaceae, although that was implied by the original generic assignment. The affinity of this species also is unlikely to be with the Myricaceae, as might be inferred from Frederiksen's (1988) comments on the genus Triatriopollenites.

Triatriopollenites granulatus is rare in Tullock Member in the Powder River Basin. In our study it was present in only two samples from the Leverett Butte locality in Wyoming.

\section{Triatriopollenites subtriangulus (Stanley) Frederiksen}

Plate 9, figures 5, 6

Triatriopollenites subtriangulus is one of three commonly occurring species of probable betulaceous or myricaceous affinity in the Tullock palynoflora. The three species are Triatriopollenites subtriangulus (Stanley) Frederiksen, Triporopollenites infrequens (Stanley) Frederiksen, and Triporopollenites granilabratus (Stanley) n. comb. Leffingwell (1970) referred pollen from the Powder River Basin having the morphology of these species to his "Betulaceae-Myricaceae-Casuarinaceae Complex," and Jerzykiewicz and Sweet (1986, pl. 3, fig. 3), who had similar specimens from the uppermost Cretaceous and lower Tertiary in Alberta, designated them "BetulaceaeMyricaceae pollen." Pollen of this general morphology is common in the lower Tertiary throughout North America and elsewhere in the world; distinguishing either conspecific or slightly different species with certainty is difficult, and there has been uncertainty about the genera or form genera to which they should be assigned. Because Stanley's (1965) type specimens from the lower Paleocene of South Dakota are unavailable for study, ultimate resolution of taxonomic and nomenclatural problems associated with these species may be unattainable. The discussion of these three species herein is based on specimens from the Tullock Member in the Powder River Basin, which on the basis of geographic proximity are more likely to be conspecific with the South Dakota specimens than are others that have been described from the Atlantic and Gulf Coasts, Europe, or elsewhere.

Triatriopollenites subtriangulus was originally described from the lower Paleocene Ludlow and Cannonball Members of the Fort Union Formation in South Dakota by Stanley (1965). He assigned it to the modern genus Carpinus in the Betulaceae (birch family), but it is unlikely that the botanical affinity of this species is with the Betulaceae. The structure of the exine at the pores shows clearly that it is not a species Carpinus. Furthermore, presence of weakly developed atria at the pores suggests affinity closer to the Myricaceae (bayberry family) than to the Betulaceae. Oltz (1969) transferred Stanley's species to the form genus Triporopollenites, and Norton and Hall (1969) apparently identified similar specimens as Triporopollenites coryloides Pflug. However, careful inspection of Stanley's original illustrations (1965, pl. 43, figs. 12-16) and well-preserved Tullock specimens reveals the presence of a weakly developed endopore and poorly defined atrium, features characteristic not of Triporopollenites but of the form genus Triatriopollenites. Frederiksen (1979) transferred Stanley's species to Triatriopollenites, and we follow that assignment here, although the atriate structure of the pores is obscure. We reject the subsequent reassignment of the species to the form genus Carpinipites 
(Zhu and others, 1985); Carpinipites does not differ significantly from Triporopollenites.

Triatriopollenites subtriangulus differs from Triatriopollenites granulatus in larger size, more triangular shape, and lesser degree of development of atria at the pores. It differs from Tullock species of Triporopollenites in having atriate pores and in lacking annuli.

In the Tullock Member Triatriopollenites subtriangulus was present in about half of the samples studied in detail. It was present in coal and all fine-grained clastic rock types.

Triporopollenites granilabratus (Stanley) n. comb.

Plate 9, figures 1, 2

Basionymn: Corylus granilabrata Stanley, 1965, p. 293, pl. 43, figs. 17-28.

Triporopollenites granilabratus is the second of three commonly occurring species of probable betulaceous or myricaceous affinity in the Tullock palynoflora. The other species are Triporopollenites infrequens (Stanley) Frederiksen and Triatriopollenites subtriangulus (Stanley) Frederiksen. Refer to the general comments on these species in the first paragraph under Triatriopollenites subtriangulus.

Triporopollenites granilabratus . was originally described by Stanley (1965) from the Ludlow Member of the Fort Union Formation in northwestern South Dakota. He assigned the species to Corylus, a modern genus in the Betulaceae (birch family), but the morphology of neither this fossil species nor pollen of living species of Corylus is distinctive enough to permit this assignment to be verified. Consequently, assignment to a form genus is more appropriate. Norton (in Norton and Hall, 1969) transferred Stanley's species to the form genus Triatriopollenites, which is characterized by presence of atriate pores in which the endexinal layer forms an endopore having much greater diameter than the exopore. Their specimen (1969, pl. 5, fig. 18) possibly shows such structure at the pores (although the photomicrograph is unclear), but their specimen does not closely resemble Stanley's (1965, pl. 43, fig. 17-28), nor ours from the Powder River Basin. All but one of Stanley's specimens and all of ours show thickening of the exine at the pores (small annuli). If the pores are annulate and not atriate, the species is cannot be assigned to Triatriopollenites.

Srivastava (1972a) transferred Stanley's species to the form genus Casuarinidites, which is based on a triporate species from the Southern Hemisphere. Frederiksen and Christopher. (1978) noted that subtle but important differences exist between North American and Southern Hemisphere triporates of this general morphology, but at that time they followed Srivastava's use of Casuarinidites for the North American species. More recently, Frederiksen (1988) reviewed the morphology, taxonomy, and nomenclature of some species of betulaceoid and myricaceoid morphology from North America and Europe, and the form genera Triporopollenites, Triatriopollenites, and Casuarinidites. He concluded that the North American species of this general morphology were inappropriately assigned to Casuarinidites. However, he also concluded that Stanley's species "Corylus" granilabrata should be assigned to Triatriopollenites, following Norton and Hall (1969). We do not follow that assignment because we maintain that Tullock specimens we believe to be conspecific with Stanley's are annulate, not atriate. Consequently, we have reassigned this species to the form genus Triporopollenites.

Triporopollenites granilabratus differs from Triporopollenites infrequens, one of the other two betulaceoidmyricaceoid species in the Tullock palynoflora, in having small (rather than well developed) annuli around the pores. It differs from Triatriopollenites subtriangulus, the other betulaceoid-myricaeoid species, in having annuli and lacking atria. Triporopollenites granilabratus differs from Triporopollenites plektosus, a non-betulaceoid-myricaceoid triporate species, in having a rounded triangular outline and in lacking random folds in the exine. It differs from Triatriopollenites granulatus in lacking atria and in being considerably larger and having a more triangular amb.

In the Tullock Member Triporopollenites granilabratus was present in about half of the samples studied in detail. It was present in coal and all fine-grained rock types.

\section{Triporopollenites infrequens (Stanley) Frederiksen}

Plate 9, figures 3,4

Triporopollenites infrequens is the third of the three commonly occurring species of probable betulaceous or myricaceous affinity in the Tullock palynoflora (the other two are Triporopollenites granilabratus and Triatriopollenites subtriangulus). Refer to the general comments on these species in the first paragraph under Triatriopollenites subtriangulus.

Triporopollenites infrequens is triporate and has a rounded triangular amb and scabrate exine; the pores are distinctly annulate. However, the pores are not vestibulate, and thus Stanley's (1965) original assignment of this species to the modern genus Betula is unjustified. Triporopollenites infrequens differs from Triatriopollenites subtriangulus in having annulate pores and in lacking atria and from Triporopollenites granilabratus in having thicker, more prominent annuli, which make the pores clearly aspidate. Among the Tullock triporates, Triporopollenites infrequens is most similar to $T$. granilabratus and can be distinguished from it primarily by the relatively more robust development of the annuli and secondarily by slightly smaller modal diameter. 
Stanley described his specimens as having vestibulate pores, but his illustrations (1965, pl. 43, figs. 7-11) do not show this feature. Frederiksen (1988) transferred Stanley's species to Triporopollenites. The form genus Triporopollenites is more appropriate for fossil specimens having annuli without vestibulae than is the modern genus Betula. The affinity of $T$. infrequens may be with the Betulaceae, but it is not with Betula.

Triporopollenites infrequens may have occurred in as many as half of our Tullock samples, but the difficulty with which it is distinguished from $T$. granilabratus during low-power scans of slides may have resulted in it being counted along with the latter species. It apparently was present in coal and all fine-grained rock types.

\section{Triporopollenites plektosus Anderson}

Plate 8 , figures $21-23$

Triporopollenites plektosus is one of three species in the Tullock palynoflora that we assign to the genus Triporopollenites. It differs from the other two in not having a morphology that suggests affinity with the modern family Betulaceae. Triporopollenites plektosus is triporate and has a thin, scabrate exine. The pores are circular and have narrow annuli. The thin exine causes the grains to become irregularly folded on compression, and most specimens exhibit randomly oriented folds. Specimens are always almost circular in outline and were probably close to spheroidal in form before compression. As a consequence of the compression of these thin spheroidal forms, the pores are not necessarily located at the edge of compressed specimens.

Triporopollenites plektosus was originally described from the uppermost Cretaceous and lower Paleocene in New Mexico (Anderson, 1960). Subsequently it was reported from the Upper Cretaceous Lance Formation and Paleocene Tullock and Lebo Members of the Fort Union Formation in the Powder River Basin (Leffingwell, 1970) and from the Upper Cretaceous and Paleocene Coalspur Formation in Alberta (Jerzykiewicz and Sweet, 1986). The botanical affinity of the species is uncertain.

This species tends to dominate some assemblages in the Coalspur Formation (Jerzykiewicz and Sweet, 1986). In the Tullock Member it is generally rare. It was present in the lower, middle, and upper parts of the unit in fine-grained clastic rock types and was absent from coal.

\section{Ulmipollenites krempii (Anderson) Frederiksen}

Plate 9, figures 7, 8

Ulmipollenites krempii includes triporate specimens and those having four or five pores at the equator (stephanoporate) and that have fine verrucate sculpture. Some specimens have arci between two or more adjacent pores. Through compression, one or more pores of some specimens may appear to be displaced from the equator.

Ulmipollenites krempii was originally described by Anderson (1960) from the uppermost Cretaceous and lower Paleocene in New Mexico. He placed the species in his new genus, Ulmoideipites. That genus is synonymous with Ulmipollenites Wolff, however, because it differs in no important way. Frederiksen (1979) transferred Anderson's species to Wolff's genus. The binomial Ulmipollenites krempii was used previously for pollen of this morphology in the Powder River Basin by Pocknall (1987). Stanley (1965) did not record any specimens under either Ulmipollenites or Ulmoideipites, although they were present in his samples. He misidentified some of them and erroneously assigned them to the modern juglandaceous genus Carya, as C. paleocenica Stanley. Norton and Hall (1969) assigned similar specimens from the Hell Creek and Tullock in Montana to species of both Ulmipollenites and Ulmoideipites. Leffingwell (1970) assigned specimens from the Lance and Fort Union Formations to Ulmipollenites. He distinguished two size classes among his specimens, those from 16 to $25 \mu \mathrm{m}$ in diameter, and those from 25 to $35 \mu \mathrm{m}$ (the larger specimens are more common in the upper part of the Fort Union than in the Tullock Member). In our study, we initially distinguished specimens less than or greater than $20 \mu \mathrm{m}$, but finally assigned all of them to a single taxon, Ulmipollenites krempii.

Ulmipollenites krempii is one of the most commonly occurring species in the Tullock palynoflora in the Powder River Basin. It was present in all but two samples studied in detail.

\section{Angiosperm Pollen-Multiporate}

\section{Chenopodipollis spp.}

Plate 9, figures 9, 10 .

Chenopodipollis spp. includes pollen grains that are spheroidal and periporate and have 20-30 circular, unbordered pores evenly distributed over their surfaces. The exine is tectate and either finely granulate or finely foveolate. More than one species might be distinguished on the basis of pore diameter and number and exine sculpture, but in this study all specimens conforming to this general description were grouped in one taxon.

Pollen of this morphology apparently has not been reported previously in the Tullock Member or equivalents in the Powder River Basin or elsewhere in the Rocky Mountain region. It was not described or illustrated by Stanley (1965), Norton and Hall (1969), or Leffingwell (1970). It has been reported from the upper Paleocene of the Gulf Coast in Texas (Elsik, 1968; Nichols and Traverse, 1971). Its botanical affinity probably is with the Chenopodiaceae (goosefoot family) or Amaranthaceae (pigweed 
family); both families have living species that produce pollen of closely similar morphology.

Chenopodipollis spp. was present in about one-third of our Tullock samples but not in high relative abundance. It was present in coal, carbonaceous shale, and mudstone at localities in both Montana and Wyoming.

\section{Erdtmanipollis cretaceus (Stanley) Norton}

Plate 9, figures 11,12

Erdtmanipollis cretaceus is spheroidal and periporate and has distinctive crotonoid-reticulate sculpture. Each pore is ringed by a rosette of sculptural elements that are elongate or triangular in form and are aligned radially; the rosettes are interconnected in a reticulate pattern. Specimens are from 20 to $40 \mu \mathrm{m}$ in diameter. In poorly preserved specimens the sculpture can be stripped off, leaving a relatively smooth periporate form. Most Tullock specimens are well preserved.

Erdtmanipollis cretaceus was first described by Stanley (1965), who assigned it to the modern genus Pachysandra (Buxaceae). Species of this genus produce pollen having the same distinctive morphology as the fossils but so do species of the modern genus Sarcococca, in the same family. The form genus Erdtmanipollis Krutzsch includes pollen of this morphology and is more appropriate because it is uncertain which modern genus may be represented by the fossils. Norton (in Norton and Hall, 1969) transferred Stanley's species to Krutzsch's genus. Oltz (1969) and Srivastava (1972b) each attempted to make the same new combination, but Norton and Hall's publication preceded theirs. Srivastava (1969) described closely similar forms from the uppermost Cretaceous of Alberta but named them E. albertensis. We regard the Canadian specimens as conspecific with $E$. cretaceus. Botanical affinity is with the Buxaceae (box tree family).

Erdtmanipollis cretaceus was present in about onefourth of our samples from the Tullock Member. We also noted its presence in the Lance Formation. It is more common in coal than in clastic rock types and more common in the Montana part of the basin than in Wyoming.

\section{Penetetrapites inconspicuus Sweet}

Plate 9, figures $13-15$

Penetetrapites inconspicuus is triangular to circular in outline although due to random folding of its thin exine, it tends to be irregular in shape. It has three or four large, vaguely defined, poroid apertures, one of which may be polar rather than equatorial in position. The form of the grain and nature and position of the apertures is reminiscent of pollen of modern species of Cyperaceae.

This species was originally described by Sweet (1986), based on specimens from the Coalspur Formation in Alberta; Sweet noted that it also is present in the uppermost
Cretaceous and lower Paleocene of southwestern Saskatchewan. It has not been reported previously from the Powder River Basin. The botanical affinity of $P$. inconspicuus is not certain, but its morphology, especially that of the apertures, suggests that it may be related to the Cyperaceae (sedge family). If this pollen does indeed represent ancestral sedges, its occurrence suggests the presence of wetland depositional environments.

Penetetrapites inconspicuus is rare in the Tullock Member. We found it only in carbonaceous shale from the Dry Creek, Montana, and Lance Creek, Wyoming, localities. In these samples it is associated with Pandaniidites typicus and Sparganiaceaepollenites sp., both of which also are interpreted to represent marsh plants.

\section{Wodehouseia fimbriata Stanley}

Plate 10, figure 12

Wodehouseia fimbriata is one of two species of oculate pollen present in the Tullock palynoflora. The body of the grain is an elongate oval surrounded by a wide fimbriate flange. There are four pores, two on each side of the grain, at either end.

Wodehouseia fimbriata was originally described by Stanley (1961a) from the Ludlow Member of the Fort Union Formation in northwestern South Dakota. It also has been reported from the Tullock Member in the Hell Creek area of east-central Montana (Norton and Hall, 1967, 1969; Oltz, 1969) and the lower Paleocene in central Alberta (Russell and Singh, 1978; Demchuck, 1990). This species has never been reported from the Upper Cretaceous and probably is restricted to the lower Paleocene. It has not been reported previously in the Powder River Basin.

This species is rare in the Tullock Member in the Powder River Basin. It was found in only one sample of shale from the lower part of the unit at the Reno Creek, Montana, locality. This species serves as a guide fossil for the lower Paleocene, but it probably is near the southern limit of its paleogeographic range in southeastern Montana and northwestern South Dakota, where it was first described.

\section{Wodehouseia spinata Stanley}

Plate 10 , figures 10,11

Wodehouseia spinata is the second species of oculate pollen in the Tullock palynoflora. Like W. fimbriata, it has an elongate, oval body and four pores. It also has a prominent flange surrounding the body, but the flange is narrower and is supported by a few rigid spines. Spines also are present as sculptural elements on the body of the grain.

This species was originally described by Stanley (1961a) from the Hell Creek Formation in northwestern 
South Dakota. It has been reported widely in the uppermost Cretaceous of . western North America (references in Nichols and Jacobson, 1982, p. 142). Nichols and others (1983) named their uppermost Cretaceous palynostratigraphic zone for Wodehouseia spinata. Stanley (1961a) and Norton and Hall (1967) believed this species to be restricted to the Cretaceous, but it also is present rarely in the lowermost Paleocene in Wyoming (Leffingwell, 1971), Montana (this study), North Dakota (Johnson and others, 1989), and Alberta (Jerzykiewicz and Sweet, 1986; Lerbekmo and others, 1987).

Wodehouseia spinata is rare in the Tullock Member. It was found in only two samples from localities in Montana, a coal from the East Beaver Creek locality and a carbonaceous shale from the Dry Creek locality. In contrast, it is relatively common in the Lance and especially in the Hell Creek Formations in Wyoming, Montana, and the Dakotas.

\section{Angiosperm Pollen-Jugate}

\section{Dyadonapites reticulatus Tschudy}

Plate 9 , figures $16-18$

Specimens of Dyadonapites reticulatus are inaperturate dyads. Individual grains of the dyad are spheroidal to ovoidal in form and equal or subequal in size. The exine is thin and the sculpture is finely reticulate.

This species was originally described by B.D. Tschudy (1973) from the Judith River Formation (Upper Cretaceous, Campanian) in Montana. It was previously reported in the uppermost Cretaceous and lowermost Paleocene in Saskatchewan (Nichols and others, 1986), in the Lance Formation and the Tullock Member in the Powder River Basin at the Sussex K-T boundary locality (Nichols and others, 1992), and in the Tongue River Member of the Fort Union Formation in the Powder River Basin (D.T. Pocknall and D.J. Nichols, unpublished data). Its small size and unusual form may have caused it to be overlooked in other studies of the palynology of Upper Cretaceous and lower Tertiary rocks. The botanical affinity of Dyadonapites reticulatus is uncertain. Dyads are rare in the fossil pollen record. Some species of the Typhaceae (cattail family) produce obligate tetrads that have reticulate sculpture, but the individual grains of such tetrads are monoporate, as are the monad grains of other species of the Typhaceae and the morphologically similar reticulate monads of the Sparganiaceae (bur-reed family), whereas individual grains of $D$. reticulatus are inaperturate. Possibly $D$. reticulatus represents an ancestral species of one of these families.

Dyadonapites reticulatus is rare in the Tullock palynoflora. We found it in only five samples. It shows no clear pattern of stratigraphic, geographic, or lithologic distribution.
Simplicepollis rallus (Stanley) n. comb.

Plate 10 , figures $1-6$

Basionym: Ericaceaeoipollenites rallus Stanley, 1965, p. 296-297, pl. 44, figs. 15-18.

Stanley (1965) described "Ericaceaeoipollenites" rallus as inaperturate to weakly tricolpate grains arranged in tetrahedral tetrads. Well-preserved specimens from the Tullock Member in the Powder River Basin observed in differential interference contrast illumination reveal that the apertures of these tetrads are large, sometimes poorly defined ora. The form genus Ericaceaeoipollenites is a junior synonym of Ericipites Wodehouse, which encompasses pollen tetrads of rather different morphology (compact, robust tetrads with distinctly tricolporate apertures). Stanley's species requires redescription and reassignment to an appropriate genus.

Redescription-Triporate pollen united in obligate tetrahedral tetrads; individual grains spheroidal but easily distorted because exine is thin, about $0.5 \mu \mathrm{m}$. Each grain bears three large orate apertures. Pores are about 5 by $10 \mu \mathrm{m}$ in diameter and may be covered by thin membranes; apertures are difficult to resolve on many specimens. Exine ' psilate to scabrate, finely granulate on apertural membranes. Individual grains about $25 \mu \mathrm{m}$ in diameter; complete tetrads about $40 \mu \mathrm{m}$ in greatest dimension.

The form genus Simplicepollis was proposed by Harris (1965) for a generally similar species from the lower Tertiary of Australia. Simplicepollis rallus differs from $S$. meridianus Harris, type species of the genus, in having thinner exine and larger pores. Both species have large orate apertures covered by membranes. S. rallus differs from Inaperturotetradites scabratus in apertures and sculpture. The botanical affinity of $S$. rallus is uncertain, but it is unlikely to be with the Ericaceae (heath family), as was suggested by Stanley (1965), who tentatively referred it to the modern ericaceous genus Kalmia.

Simplicepollis rallus was originally described by Stanley (1965) from the Ludlow and Cannonball Members of the Fort Union Formation in South Dakota. It is abundant in the basal part of Ludlow Formation of the Fort Union Group in North Dakota (Johnson and others, 1989). In the Tullock Member of the Powder River Basin it was present in about one-third of samples studied in detail but not in high relative abundance in any of them. It was present in coal and all fine-grained clastic rock types and was more common in Wyoming than in Montana.

\section{Inaperturotetradites scabratus Tschudy}

Plate 10 , figure 7

Specimens of Inaperturotetradites scabratus are inaperturate tetrads. Individual grains of the tetrad are spheroidal or nearly so and are arranged in a tetrahedral 
pattern. The exine is thin, less than $1 \mu \mathrm{m}$, and scabrate. The diameter of Tullock specimens is $35-40 \mu \mathrm{m}$.

This species was originally described by B.D. Tschudy (1973) from the Judith River Formation (Upper Cretaceous, Campanian) in Montana. She noted that it is also present in Campanian and Maastrichtian rocks elsewhere in Montana and in Wyoming. Our record from the Tullock Member extends the range of the species to the lower Paleocene.

Tschudy (1973) discussed the superficial resemblance of Inaperturotetradites scabratus and the tetrad Simplicepollis rallus (which she referred to by its original name, Ericaceoipollenites rallus) and the possibility that the two species might turn out to be synonymous. The Tullock specimens of these species show the clear morphologic distinction that exists between these species: $I$. scabratus is inaperturate (as recognized and described by Tschudy) and $S$. rallus has poorly developed but definite orate to colpate apertures (as described by Stanley, 1965, and herein); the exines differ also, being distinctly scabrate in I. scabratus and psilate to scabrate in $S$. rallus.

Inaperturotetradites scabratus is rare in the Tullock palynoflora. We recorded it only at the Dry Creek and Reno Creek localities, in the lower part of the Tullock Member.

\section{Angiosperm Pollen-Triprojectate}

\section{Aquilapollenites reticulatus (Mtchedlishvili) Tschudy \& Leopold}

Plate 10 , figures 8,9

The morphology of Aquilapollenites reticulatus is one of the most distinctive of any species of fossil palynomorph in the Tullock palynoflora. It is one of the species of triprojectate pollen whose morphology is not only unusual among fossil forms but is unknown among pollen of living plants. Aquilapollenites reticulatus has an ovoid body and three short equatorial protrusions that bear colpate apertures. The exine is finely but distinctly reticulate.

The taxonomic and nomenclatural history of this species is somewhat unusual if not complex. Aquilapollenites reticulatus was first described by Mtchedlishvili (in Samoilovich and others, 1961) from Siberia as "Parviprojectus" reticulatus. Later that same year, Stanley (1961b) described essentially identical specimens from South Dakota that he named Aquilapollenites reticulatus. His species is synonymous with Mtchedlishvili's. Tschudy and Leopold (1971), in their monographic treatment of the genus Aquilapollenites, transferred Mtchedlishvili's species to Aquilapollenites, which made Stanley's species a homonym as well as a synonym. We follow Tschudy and Leopold and reject assignment of this species to Integricorpus.

Aquilapollenites reticulatus survived the $\mathrm{K}-\mathrm{T}$ extinction event, whereas most species of the genus did not.
This species is more common in the uppermost Cretaceous of the Rocky Mountain region than in the lowermost Paleocene, but it has been recorded from the Paleocene in Alberta by Jerzykiewicz and Sweet (1986), in North Dakota by Johnson and others (1989), and in Montana and Wyoming (this study).

Aquilapollenites reticulatus is rare in Tullock palynoflora. In this study it was recorded in only two samples from lower part of the Tullock Member, in shale from the Reno Creek locality in Montana and in mudstone from the South Snyder Creek locality in Wyoming.

\section{CONCLUSIONS}

On the basis of the comparison of assemblages of fossil palynomorphs discussed here and by its position above the palynologically defined Cretaceous-Tertiary (K-T) boundary, the age of the Tullock Member is determined to be early Paleocene, equivalent to palynostratigraphic zones P1 and P2 of Nichols and Ott (1978). Palynomorph assemblages of the Tullock Member are distinguishable from those of the underlying Lance and Hell Creek Formations and the overlying Lebo Member of the Fort Union Formation. Lowermost Paleocene assemblages also are present in the uppermost parts of the underlying, predominantly Cretaceous units at some localities in the Powder River Basin. At other places the base of the Tullock is coincident with the $\mathrm{K}-\mathrm{T}$ boundary. The Tullock Member in the Powder River Basin is mostly or entirely biostratigraphically correlative with the Tullock Member in eastern Montana; the Tullock, Ludlow, and Cannonball Members in northwestern South Dakota; the Tullock, Ludlow, and Cannonball Formations in southwestern North Dakota; and, with less precision, the lower part of the lower unnamed member of the Fort Union Formation in the Wind River Basin in Wyoming.

The palynostratigraphic zonation of the lower Paleocene can be revised to some extent, based on results of our study of assemblages from the Tullock Member. The biostratigraphically important species of the pollen genus Momipites that defines palynostratigraphic zone $\mathrm{P} 1$ in the Wind River Basin is absent from the basal Paleocene in the Powder River Basin, appearing first in the middle part of the Tullock Member. Zone P1 in the Powder River Basin is characterized by presence of Momipites inaequalis instead of $M$. leffingwellii, the species that defines zone $\mathrm{P} 1$ in the Wind River Basin. Zone P2 in the Powder River Basin is characterized by presence of Momipites inaequalis, $M$. leffingwellii, $M$. tenuipolus, $M$. waltmanensis, and $M$. wyomingensis; the last two species named characterize zone P2 in the Wind River Basin. The presence of $M$. inaequalis and M. tenuipolus in the lower Paleocene in the Powder River Basin indicates strong biostratigraphic similarity with the lower Paleocene of the Raton Basin of southern Colorado and New Mexico, based on data of Fleming (1990). The 


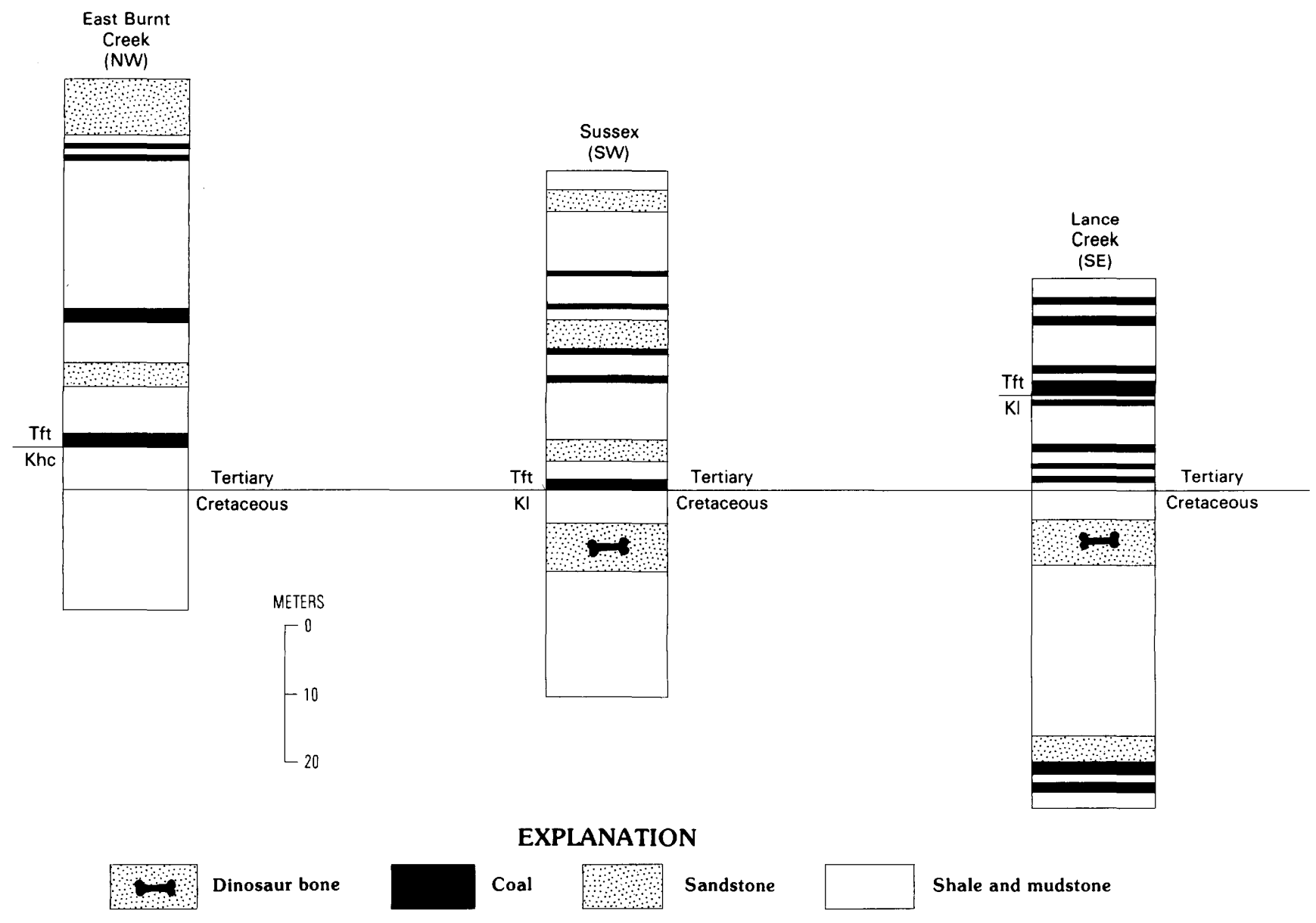

Figure 5. Relationship between the Cretaceous-Tertiary $(\mathrm{K}-\mathrm{T})$ boundary, which is defined on the basis of palynostratigraphy (this study), and formation contacts, which are placed at the base of the first persistent coal bed above the stratigraphically highest dinosaur remains, at three sections in the Powder River Basin. No dinosaur bones were present in the East Burnt Creek section, but the coal bed shown is bed A of Rogers and Lee (1923), the base of the Fort Union Formation in that area. Khc, Hell Creek Formation; KI, Lance Formation; Tft, Tullock Member of the Fort Union Formation. Locations of sections shown in figures 3 and 4.

presence of Wodehouseia fimbriata in the Tullock in the Montana part of the Powder River Basin indicates biostratigraphic similarity with the lower Paleocene of Alberta, based on data of Demchuk (1990).

The palynoflora of the Tullock Member in the Powder River Basin includes 75 or more taxa. Excluding algae, which constitute about 12 percent of the taxa discussed here, the palynoflora is dominated by pollen of angiosperms (70 percent) and includes pollen of gymnosperms (10 percent) and spores of pteridophytes and bryophytes (20 percent). The most commonly occurring taxa are pollen of a palm (Arecipites tenuiexinous), platanaceous(?) and ulmaceous dicots (Tricolpites spp. and UImipollenites krempii), and conifers (Pityosporites spp.) and spores of ferns (Cyathidites diaphana, Laevigatosporites spp., and Reticuloidosporites pseudomurii). Locally abundant taxa tend to dominate some assemblages, reflecting concentration of parent plants in certain depositional environments. Among the angiosperms these taxa are the palm and ulmaceous dicot mentioned above, pollen of betulaceous and (or) myricaceous dicots (some species of Triporopollenites and Triatriopollenites) and dicots of uncertain affinity (Kurtzipites spp.), and pollen of a probably pandanaceous dicot (Pandanildites typicus). Among the pteridophytes and bryophytes locally abundant taxa are the ferns mentioned above, two other species of fern (Toroisporis major and Gleicheniidites sp.), and sphagnum moss (Stereisporites spp.). No gymnosperms are believed to have been locally abundant in Tullock depositional environments. Conifer pollen (Pityosporites spp.), which is attributed to pines, probably was transported from adjacent highland areas by wind and water. No palynomorph species is known to be stratigraphically restricted to the Tullock Member, but four species that range into the Tullock from the underlying Cretaceous (Aquilapollenites reticulatus, Kurtzipites circularis, $K$. trispissatus, and Wodehouseia spinata) range no higher than the Tullock in the Powder River Basin.

The relative abundances of pollen and spores indicate that Tullock plant communities probably consisted of wet- 


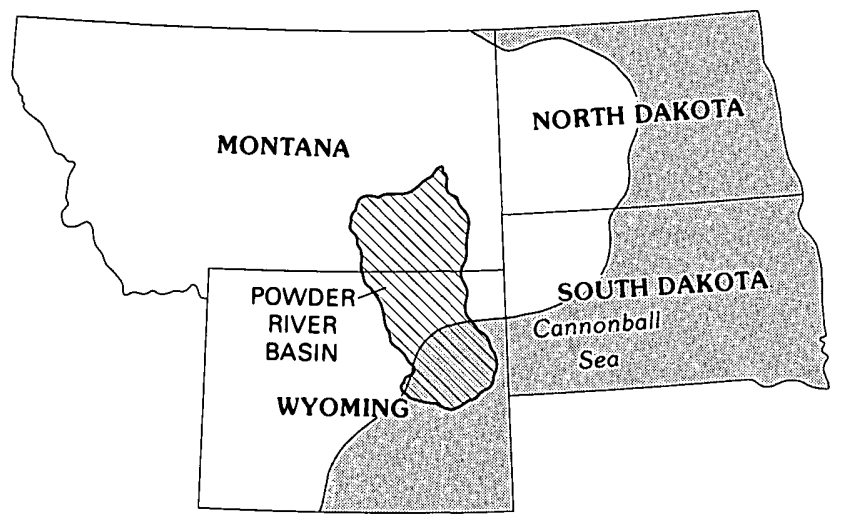

Figure 6. Paleogeography of the area of the Powder River Basin in earliest Paleocene time. Readvance of the Western Interior seaway (Cannonball Sea) would tend to pond drainage progressively from southeast to northwest in the area that was to become the Powder River Basin. Ponding would promote accumulation of peat that later formed coal deposits of the Tullock Member. The structural basin developed later in Paleocene time. Paleogeography from Cherven and Jacob (1985, fig. 25).

lands and mires interspersed among lowland forests of warm temperate to subtropical aspect: Mires were inhabited mostly by ferns and in some places by sphagnum moss. The forests were dominated by a somewhat unusual mix of palms and deciduous trees including Ulmaceae, Platanaceae, and Betulaceae. The paleoclimatic interpretations we draw from this vegetation differ from those of an earlier study by Hall and Norton (1967), who placed undue emphasis on the presence of conifer pollen in the Tullock Member in eastern Montana and concluded that early Paleocene climates were considerably cooler than we believe. Our conclusions are consistent with more recent interpretations by Wolfe (in Nichols and others, 1988), which are based on the physiognomy of megafossil (leaf) assemblages.

Some implications for sedimentary history of the Tullock Member can be drawn from the palynology of the Tullock Member. They supplement the major conclusions based on the sedimentology of the Tullock (Brown, in press). Tullock-style deposition, as defined by presence of carbonaceous zones and coal beds, was initiated in early but not earliest Paleocene time in the northwestern part of the Powder River Basin. This observation in conjunction with the presence of coal beds in the upper part of the Lance Formation and the transitional nature of the Lance-Tullock contact in the southeastern part of the basin (Clemens, 1964; Leffingwell, 1970) suggests that Tullock depositional environments spread from southeast to northwest across the basin in the early Paleocene. This conclusion is illustrated clearly by the relationship of the palynologically defined $\mathrm{K}-\mathrm{T}$ boundary to the Lance-Tullock and Hell Creek-Tullock lithostratigraphic contacts (fig. 5). The K-T boundary datum, which is a time line, shows that the formation contact is time transgressive from southeast to northwest across the basin.

Wolfe and Upchurch (1986) invoked a sudden increase in precipitation following the $\mathrm{K}-\mathrm{T}$ boundary event to explain putative widespread initiation of peat deposition in the northern High Plains in earliest Paleocene time. Data summarized in figure 5 for the Powder River Basin and by Johnson and others (1990) for the southwestern Williston basin are evidence against that hypothesis. The more likely control on early Paleocene paleoenvironments was temporary readvance of the Western Interior seaway, represented by the Cannonball deposits of the Dakotas. The readvance gradually raised base level and tended to pond the slowly flowing streams in the region of the Powder River Basin (Nichols and Brown, 1989, 1990). Ponded drainage promoted peat accumulation, and ponding affected local areas at varying times, not simultaneously. In the area that was to become the Powder River Basin, base level rose progressively from southeast to northwest. Peat accumulation began before the end of Cretaceous time in the southeast (Lance Creek, Wyoming), was essentially coincident with the $\mathrm{K}-\mathrm{T}$ boundary in the southwest (Sussex, Wyoming), and did not begin until well into the early Paleocene in the northwest (East Burnt Creek, Montana). This conclusion is supported by regional paleogeographic mapping by Cherven and Jacob (1985). Their map, adapted here as figure 6 , pertains primarily to the Williston basin area, and the presence of marine deposits in the southern Powder River Basin implied by their map is not supported by our palynological study of the Tullock Member. However, the general pattern of readvance of the sea probably is correct, and the progressive change in base level that would be a consequence explains the stratigraphic distribution of coal shown in figure 5 .

Our final conclusion concerns the Tullock coals themselves. The peat that eventually formed the Tullock coals was deposited in mires inhabited primarily by ferns. The vegetation of these coal-forming depositional environments differed from that which developed later in the Paleocene during deposition of the Tongue River Member of the Fort Union Formation and which was predominantly woody. The predominance of herbaceous rather than woody vegetation in Tullock mires may account in part for Tullock coals being thinner and less extensive than the younger Fort Union coals.

\section{REFERENCES CITED}

Anderson, R.Y., 1960, Cretaceous-Tertiary palynology, eastern side of the San Juan basin, New Mexico: New Mexico State Bureau of Mines and Mineral Resources Memoir 6, 58 p., 11 pls. 
Bergad, R.D., 1973, North American species of the Cretaceous megaspores Balmeisporites and Monophyllosporites: Micropaleontology, v. 19, p. 53-67, pls. 1-4.

Bohor, B.F., Triplehorn, D.M., Nichols, D.J., and Millard, H.T., Jr., 1987, Dinosaurs, spherules, and the "magic" layer-A new K-T boundary clay site in Wyoming: Geology, v. 15 , p. 896-899.

Brown, J.S., in press, Sedimentology and depositional history of the lower Paleocene Tullock Member of the Fort Union Formation, Powder River Basin, Wyoming and Montana: U.S. Geological Survey Bulletin 1917-L.

Brown, J.L., and Nichols, D.J., 1988, Lithostratigraphy and biostratigraphy of the Cretaceous-Tertiary transition in the northwestern Powder River basin-A new, interdisciplinary look at a classic area: Geological Society of America, Abstracts with Programs, v. 20, no. 7, p. A316.

Brown, R.W., 1962, Paleocene flora of the Rocky Mountains and Great Plains: U.S. Geological Survey Professional Paper 375,119 p., 69 pls.

Calvert, W.R., 1912, Geology of certain lignite fields in eastern Montana: U.S. Geological Survey Bulletin 471, p. 187-201.

Cherven, V.B., and Jacob, A.F., 1985, Evolution of Paleogene depositional systems, Williston basin, in response to global sea level changes, in Flores, R.M., and Kaplan, S.S., eds., Cenozoic paleogeography of the west-central United States: Society of Economic Paleontologists and Mineralogists, Rocky Mountain Section, Rocky Mountain Paleogeography Symposium 3, Denver, p. 127-170.

Clemens, W.A., 1964, Fossil mammals of the type Lance Formation, Wyoming-Part 1, Introduction and Multituberculata: University of California Publications in Geological Science, v. 48, 105 p.

Cookson, I.C., and Dettmann, M.E., 1959, On Schizosporis, a new form genus from Australian Cretaceous deposits: Micropaleontology, v. 5, p. 213-216, pl. 1.

Demchuk, T.D., 1990, Palynostratigraphic zonation of Paleocene strata in the south-central Alberta Plains: Canadian Journal of Earth Sciences, v. 27, p. 1263-1269.

Dettmann, M.E., 1963, Upper Mesozoic microfloras from southeastern Australia: Proceedings of the Royal Society of Victoria, v. 77, p. 1-152, pls. 1-27.

Dobbin, C.E., Kramer, W.B., and Horn, G.H., 1957, Geologic and structure map of the southeastern part of the Powder River Basin, Wyoming: U.S. Geological Survey Oil and Gas Investigations Map OM-185, 1:125,000.

Doher, L.I., 1980, Palynomorph preparation procedures currently in use in the paleontology and stratigraphy laboratories, U.S. Geological Survey: U.S. Geological Survey Circular $830,29 \mathrm{p}$.

Elsik, W.C., 1968, Palynology of a Paleocene Rockdale lignite, Milam County, Texas; 1, Morphology and taxonomy: Pollen et Spores, v. 10, p. 263-314, pls. 47-61.

Erdtman, Gunnar, 1957, Pollen and spores morphology/plant taxonomy-Gymnospermae, Pteridophyta, Bryophyta (illustrations): Stockholm, Almqvist \& Wiksell, 151 p.

Fleming, R.F., 1990, Palynology of the Cretaceous-Tertiary boundary interval and Paleocene part of the Raton Formation, Colorado and New Mexico: Boulder, University of Colorado, Ph.D. thesis, 283 p., 8 pls.
Frederiksen, N.O., 1979, Paleogene sporomorph biostratigraphy, northeastern Virginia: Palynology, v. 3, p. 129-167, pls. 1-4.

1980, Paleogene sporomorphs from South Carolina and quantitative correlations with the Gulf Coast: Palynology, v. 4, p. 125-179, pls. 1-4.

1988, Sporomorph biostratigraphy, floral changes, and paleoclimatology, Eocene and earliest Oligocene of the eastern Gulf Coast: U.S. Geological Survey Professional Paper 1448, 68 p., 16 pls.

Frederiksen, N.O., and Christopher, R.A., 1978, Taxonomy and biostratigraphy of Late Cretaceous and Paleogene triatriate pollen from South Carolina: Palynology, v. 2, p. 113-145, pls. 1-3.

Hall, J.W., and Norton, N.J., 1967, Palynological evidence of floristic change across the Cretaceous-Tertiary boundary in eastern Montana (U.S.A.): Palaeogeography, Palaeoclimatology, Palaeoecology, v. 3, p. 121-131.

Harris, W.K., 1965, Basal Tertiary microfloras from the Princetown area, Victoria, Australia: Palaeontographica, Abteilung B, v. 115, p. 75-106.

Hedlund, R.W., 1965, Sigmopollis hispidus gen. et sp. nov. from Miocene sediments, Elko County, Nevada: Pollen et Spores, v. 7, p. $89-92$.

Jansonius, Jan, and Hills, L.V., 1981, Genera file of fossil spores-Supplement: Special publication, University of Calgary.

Jarzen, D.M., 1979, Zygospores of Zygnemataceae in the Paleocene of southern Saskatchewan (Canada): Review of Palaeobotany and Palynology, v. 28, p. 21-25, pl. 1.

1983, The fossil pollen record of the Pandancaeae: Gardens Bulletin, v. 36, p. 163-175, pl. 1.

Jerzykiewicz, T., and Sweet, A.R., 1986, The Cretaceous-Tertiary boundary in the central Alberta Foothills; I, Stratigraphy: Canadian Journal of Earth Science, v. 23, p. 1356-1374, pls. $1-4$.

Johnson, K.R., Nichols, D.J., Attrep, Moses, Jr., and Orth, C.J., 1989, High-resolution leaf-fossil record spanning the Cretaceous/Tertiary boundary: Nature, v. 340, p. 708-711.

Johnson, K.R., Nichols, D.J., Tauxe, Lisa, and Clark, David, 1990, Floral zonation and magnetostratigraphy of the Hell Creek (Late Maastrichtian) and lower Fort Union (early Paleocene) Formations, North Dakota: Geological Society of America, Abstracts with Programs, v. 22, p. A323.

Krutzsch, Wilfried, 1959, Mikropaläontologische (sporenpaläontologische) Untersuchungen in der Braunkohle des Geiseltals: Geologie Beihefte, v. 8, no. 21-22, 425 p., 49 pls. 1960, Uber Thomsonipollis magnificus (Th. \& Pf. 1953) $n$. fgen. n. comb. und Bemerkungen zur regionalen Verbreitung einiger Pollengruppen im alteren Paläogen: Freiberger Forschungshefte, v. C86, p. 54-65, pls. 1-5.

1963, Atlas der mittel-und jungtertiären dispersen Sporenund Pollen sowie der Mikroplanktonformen des nördlichen Mitteleuropas; Lieferung 3, Sphagnaceoide und selaginellaceoide Sporenformen: Berlin, VEB Deutscher Verlag der Wissenschaften, 128 p., 43 pls.

Leffingwell, H.A., 1970, Palynology of the Lance (Late Cretaceous) and Fort Union (Paleocene) Formations of the type Lance area, Wyoming, in Kosanke, R.M., and Cross, 
A.T., eds., Symposium on palynology of the Late Cretaceous and early Tertiary: Geological Society of America Special Paper 127, p. 1-64, pls. 1-10.

Lerbekmo, J.F., Sweet, A.R., and St. Louis, R.M., 1987, The relationship between the iridium anomaly and palynological floral events at three Cretaceous-Tertiary boundary localities in western Canada: Geological Society of America Bulletin, v. 99, p. 325-330.

Lewis, B.D., and Hotchkiss, W.R., 1981, Thickness, percent sand, and configuration of shallow hydrogeologic units in the Powder River Basin, Montana and Wyoming: U.S. Geological Survey Miscellaneous Investigations Series Map I-1317, 6 sheets.

Muller, Jan, 1968, Palynology of the Pedawan and Plateau Sandstone Formations (Cretaceous-Eocene) in Sarawak, Malaysia: Micropaleontology, v. 14, p. 1-37, pls. 1-5.

1981, Fossil pollen records of extant angiosperms: Botanical Review, v. 47, p. 1-142.

Nichols, D.J., 1973, North American and European species of Momipites ("Engelhardtia") and related genera: Geoscience and Man, v. 7, p. 103-117, pl. 1.

1987, Palynology of the Vermillion Creek coal bed and associated strata, in Roehler, H.W., and Martin, P.L., eds., Geological investigations of the Vermillion Creek coal bed in the Eocene Niland Tongue of the Wasatch Formation, Sweetwater County, Wyoming: U.S. Geological Survey Professional Paper 1314-D, p. 47-73, pls. 3-6.

Nichols, D.J., and Brown, J.L., 1989, Cretaceous-Tertiary boundary in the Powder River Basin, Wyoming and Montana: American Association of Stratigraphic Palynologists, 22nd Annual Meeting, Program and Abstracts, p. 39. 1990, The Cretaceous-Tertiary boundary in the Powder River Basin, Montana and Wyoming, and its application to basin analysis: Geological Society of America, Abstracts, with Programs, v. 22, p. A364.

Nichols, D.J., Brown, J.L., Attrep, Moses, Jr., and Orth, C.J., 1992, A new Cretaceous-Tertiary boundary locality in the western Powder River Basin, Wyoming-Biological and geological implications: Cretaceous Research, v. 13.

Nichols, D.J., and Jacobson, S.R., 1982, Palynostratigraphic framework for the Cretaceous (Albian-Maestrichtian) of the overthrust belt of Utah and Wyoming: Palynology, v. 6, p. 119-147, pls. 1-4.

Nichols, D.J., Jacobson, S.R., and Tschudy, R.H., 1982, Cretaceous palynomorph biozones for the central and northern Rocky Mountain region of the United States, in Powers, R.B., ed., Geologic studies of the Cordilleran thrust belt: Rocky Mountain Association of Geologists, v. 2, p. 721-733, pl. 1.

Nichols, D.J., Jarzen, D.M., Orth, C.J., and Oliver, P.Q., 1986, Palynological and iridium anomalies at Cretaceous-Tertiary boundary, south-central Saskatchewan: Science, v. 231, p. 714-717.

Nichols, D.J., and Ott, H.L., 1978, Biostratigraphy and evolution of the Momipites-Caryapollenites lineage in the early Tertiary in the Wind River basin, Wyoming: Palynology, v. 2, p. 93-112, pls. 1-2.

Nichols, D.J., and Traverse, Alfred, 1971, Palynology, petrology, and depositional environments of some early Tertiary lignites in Texas: Geoscience and Man, v. 3, p. 37-48, pl. 1.
Nichols, D.J., Wolfe, J.A., and Pocknall, D.T., 1988, Latest Cretaceous and early Tertiary history of vegetation in the Powder River Basin, Montana and Wyoming, in Holden, G.S., ed., Geological Society of America Field Trip Guidebook 1988: Colorado School of Mines Professional Contributions, no. 12, p. 205-210, 222-226.

Norton, N.J., and Hall, J.W., 1967, Guide sporomorphae in the Upper Cretaceous-lower Tertiary of eastern Montana (U.S.A.): Review of Palacobotany and Palynology, v. 2, p. 99-110, pl. 1 .

1969, Palynology of the Upper Cretaceous and lower Tertiary in the type locality of the Hell Creek Formation, Montana, U.S.A.: Palaeontographica, Abteilung B, v. 125, p. 1-64, pls. 1-8.

Oltz, D.F., 1969, Numerical analyses of palynological data from Cretaceous and early Tertiary sediments in east central Montana: Palaeontographica, Abteilung B, v. 128, p. 90-166, pls. 39-42.

Pals, J.P., Van Geel, Bas, and Delfos, A., 1980, Paleoecological studies in the Klokkeweel bog near Hoogkarspel (Prov. of Noord-Holland): Review of Palaeobotany and Palynology, v. 30 , p. $371-418$, pls. $1-6$.

Pierce, S.T., 1976, Morphology of Schizosporis reticulatus Cookson and Dettmann 1959: Geoscience and Man, v. 15, p. 25-33, pls. 1-2.

Pocknall, D.T., 1987, Palynomorph biozones for the Fort Union and Wasatch Formations (upper Paleocene-lower Eocene), Powder River Basin, Wyoming and Montana: Palynology, v. 11, p. 23-35, pl. 1 .

Pocknall, D.T., and Flores, R.M., 1987, Coal palynology and sedimentology in the Tongue River Member, Fort Union Formation, Powder River Basin, Wyoming: Palaios, v. 2, p. 133-145.

Potonié, Robert, 1951, Revision stratigraphisch wichtiger Sporomorphen des mitteleuropäischen Tertiärs: Palaeontographica, Abteilung B, v. 91, p. 131-151.

1966, Synopsis der Gattungen der Sporae dispersae, IV. Teil-Nachträge zu allen Gruppen (Turmae): Beihefte zum Geologischen Jahrbuch, Heft 72, 244 p., 15 pls.

Rich, F.J., Kuehn, Deborah, and Davies, T.D., 1982, The paleoecological significance of Ovoidites: Palynology, v. 6, p. 19-28, pl. 1.

Russell, D.A., and Singh, Chaitanya, 1978, The CretaceousTertiary boundary in south-central Alberta-A reappraisal based on dinosaurian and microfloral extinctions: Canadian Journal of Earth Sciences, v. 15, p. 284-292.

Robinson, C.S., Mapel, W.J., and Bergendahl, M.H., 1964, Stratigraphy and structure of the northern and western flanks of the Black Hills uplift, Wyoming, Montana, and South Dakota: U.S. Geological Survey Professional Paper 404, 134 p., 5 pls.

Rogers, G.S., and Lee, Wallace, 1923, Geology of the Tullock Creek coal field: U.S. Geological Survey Bulletin 749, 181 p., 16 pls.

Samoilovich, S.R., Mtchedlishvili, N.D., Rusakova, L.I., and Iashchurzhinskaia, A.B., eds., 1961, Pollen and spores of western Siberia, Jurassic to Paleocene [in Russian]: Leningrad, Trudy Vsesoyuznogo Neftyanogo NauchnoIssledovatel'skogo Geologo-Razvedochnogo Instituta (VNIGRI), v. 177, 657 p., 149 pls. 
Simpson, J. B., 1961, The Tertiary pollen-flora of Mull and Ardnamurchan: Transactions of the Royal Society of Edinburgh, v. 64 , p. 421-468, pls. 1-20.

Srivastava, S.K., 1967, Upper Cretaceous microflora (Maestrichtian) from Scollard, Alberta, Canada: Pollen et Spores, v. 8, p. $497-552$, pls. $78-88$.

1969, Assorted angiosperm pollen from the Edmonton Formation (Maestrichtian), Alberta, Canada: Canadian Journal of Botany, v. 47, p. 975-989, pls. 1-3.

- 1971, Systematic revision of the genus Styx Norton et Hall, 1967: Review of Palaeobotany and Palynology, v. 11, p. 297-309, pls. 1-5.

1972a, Some spores and pollen from the Paleocene Oak Hill Member of the Naheola Formation, Alabama (U.S.A.): Review of Palaeobotany and Palynology, v. 14, p. 217-285, pls. $1-25$.

1972b. Pollen genus Erdtmanipollis Krutzsch 1962: Pollen et Spores, v. 14, p. 309-322, pls. 1-4.

1978, The Cretaceous megaspore genus Ghoshispora: Palaeontographica, Abteilung B, v. 167, p. 175-184, pls. $1-4$.

1981, Fossil pollen genus Kurtzipites Anderson: Journal of Paleontology, v. 55, p. 868-879, pls. 1-2.

Srivastava, S.K., and Binda, P.L., 1969, Megaspores of the genus Balmeisporites from the Upper Cretaceous of Alberta and Saskatchewan, Canada: Revue de Micropaleontologie, v. 11, p. 205-209, pls. 1-2.

Stanley, E.A., 1961 a, A new sporomorph genus from northwestern South Dakota: Pollen et Spores, v. 3, p. 155-162, pls. 1-2. 1961b, The fossil pollen genus Aquilapollenites: Pollen et Spores, v. 3, p. 329-352, pls. 55-62.

1965, Upper Cretaceous and Paleocene plant microfossils and Paleocene dinoflagellates and hystrichosphaerids from northwestern South Dakota: Bulletins of American Paleontology, v. 49, no. 222, p. 179-384, pls. 19-49.

Sweet, A.R., 1986, The Cretaceous-Tertiary boundary in the central Alberta Foothills; I, Miospore and pollen taxonomy: Canadian Journal of Earth Science, v. 23, p. 1375-1388, pls. $1-2$.

Taylor, T.N., 1981, Palcobotany: New York, McGraw-Hill, 589 p.
Tschudy, B.D., 1973, Palynology of the upper Campanian (Cretaceous) Judith River Formation, north-central Montana: U.S. Geological Survey Professional Paper 770, 42 p., 11 pls.

Tschudy, B.D., and Leopold, E.B., 1971, Aquilapollenites (Rouse) Funkhouser-Selected Rocky Mountain taxa and their stratigraphic ranges, in Kosanke, R.M., and Cross, A.T., eds., Symposium on palynology of the Late Cretaceous and early Tertiary: Geological Society of America Special Paper 127 , p. 113-167, pls. $1-4$.

Tschudy, R.H., 1961, Palynomorphs as indicators of facies environments in Upper Cretaceous and lower Tertiary strata, Colorado and Wyoming: Wyoming Geological Association Guidebook, p. 53-59.

1973, The Gasbuggy core-A palynological appraisal, in Fassett, J.E., ed., Cretaceous and Tertiary rocks of the southern Colorado Plateau: Four Corners Geological Society Memoir Book, p. 131-143.

Van Geel, Bas, 1976, Fossil spores of Zygnemataceae in ditches of a prehistoric settlement in Hoogkarspel (The Netherlands): Review of Palaeobotany and Palynology, v. 22, p. 337-344, pl. 1.

Venkatachala, B.S., 1969, Palynology of the Mesozoic sediments of Kutch-4, Spores and pollen from the Bhuj exposures near Bhuj. Gujarat District: The Palaeobotanist, v. 17, p. 208-219, pls. 1-6.

Wilson, L.R., and Webster, R.M., 1946, Plant microfossils from a Fort Union coal of Montana: American Journal of Botany, v. 33 , p. 271-278.

Wingate, F.H., 1983, Palynology and age of the Elko Formation (Eocene) near Elko, Nevada: Palynology, v. 7, p. 93-132, pls. 1-7.

Wodehouse, R. P., 1933, Tertiary pollen-II, The oil shales of the Green River Formation: Bulletin of the Torrey Botanical Club, v. 60, p. 479-524.

Wolfe; J.A., and Upchurch. G.R., Jr., 1986 Vegetation, climatic and floral changes at the Cretaceous-Tertiary boundary: Nature, v. 324, p. 148-152.

Zhu, Zunghao, Wu, Liyu, Xi, Ping, Song, Zhichen, and Zhang, Yiyong, 1985, A research on Tertiary palynology from the Qaidam basin, Qinghai Province [in Chinese]: Nanjing Institute of Geology and Paleontology, Academia Sinica, Petroleum Industry Press, 297 p. 


\section{PLATES 1-10}

-

Contact photographs of the plates in this report are available, at cost, from the U.S. Geological Survey Photographic Library, Federal Center,

Denver, CO 80225 
PLATE 1. Algal cysts and monolete spores

[All specimens $\times 1,000$. England Finder coordinates in brackets]

FIGURE 1. Schizophacus laevigatus (Stanley) n. comb. East Beaver Crcek, Mont.; slide D6937-K (1) [G51/1].

2. Schizophacus sp. Cow Creek, Wyo.; slide D7419 (1) [M44/2].

3. Sigmopollis hispidus Hedlund. East Beaver Creek, Mont.; slide D6937-K (1) [R45/2].

4. Sigmopollis sp. East Beaver Creek, Mont.; slide D6937-K (1) [N60/1].

5. Algal cyst type 1. East Beaver Creek, Mont.; slide D6937-K (1) [G44/2].

6. Algal cyst type 2. East Beaver Creek, Mont.; slide D6937-K (1) [Q48/1].

7, 8. Tetraporina spp.

7. Dry Creek, Mont.; slide D7000-B (1) [J40/2].

8. Dry Creek, Mont.; slide D7000-B (1) [L49/0].

9, 10. Incertae sedis type 1. Two levels of focus on a single specimen; South Snyder Creek, Wyo.; slide D7422-E (1) [N70/3].

11-14. Laevigatosporites $\mathrm{sp}$. L.

11. Dry Creek, Mont.; slide D7000-B (1) [N39/2].

12. Dry Creek, Mont.; slide D7000-B (1) [P40/2].

13. South Snyder Creek, Wyo.; slide D7422-E (1) [R47/0].

14. Reno Creek, Mont.; slide D7411-C (1) [G44/3] 

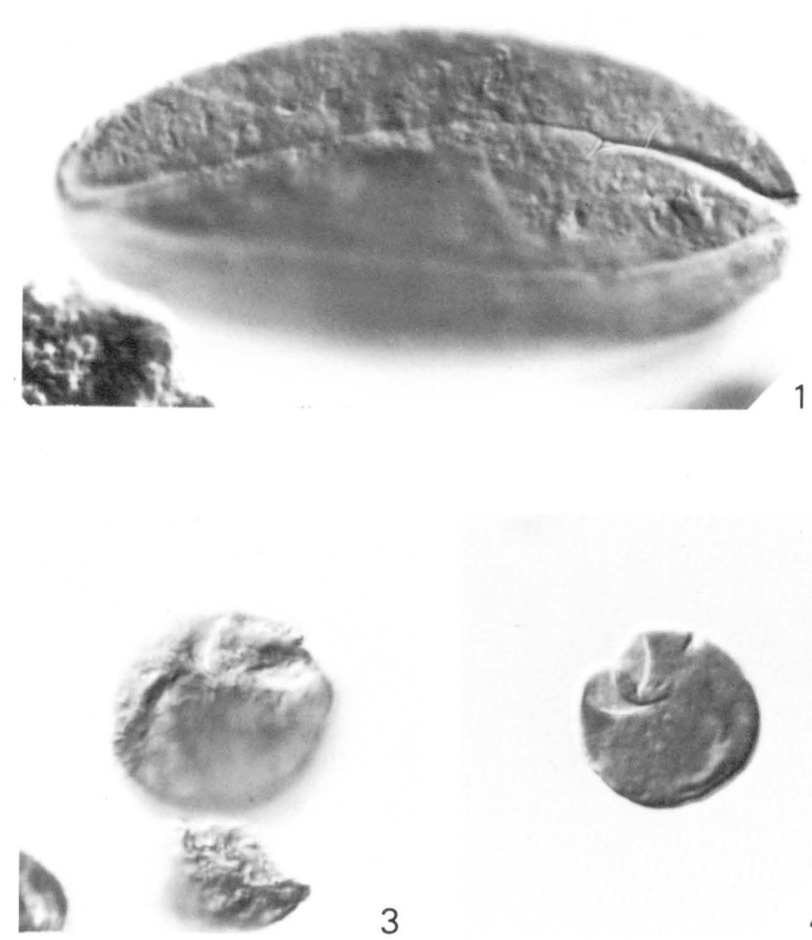

3
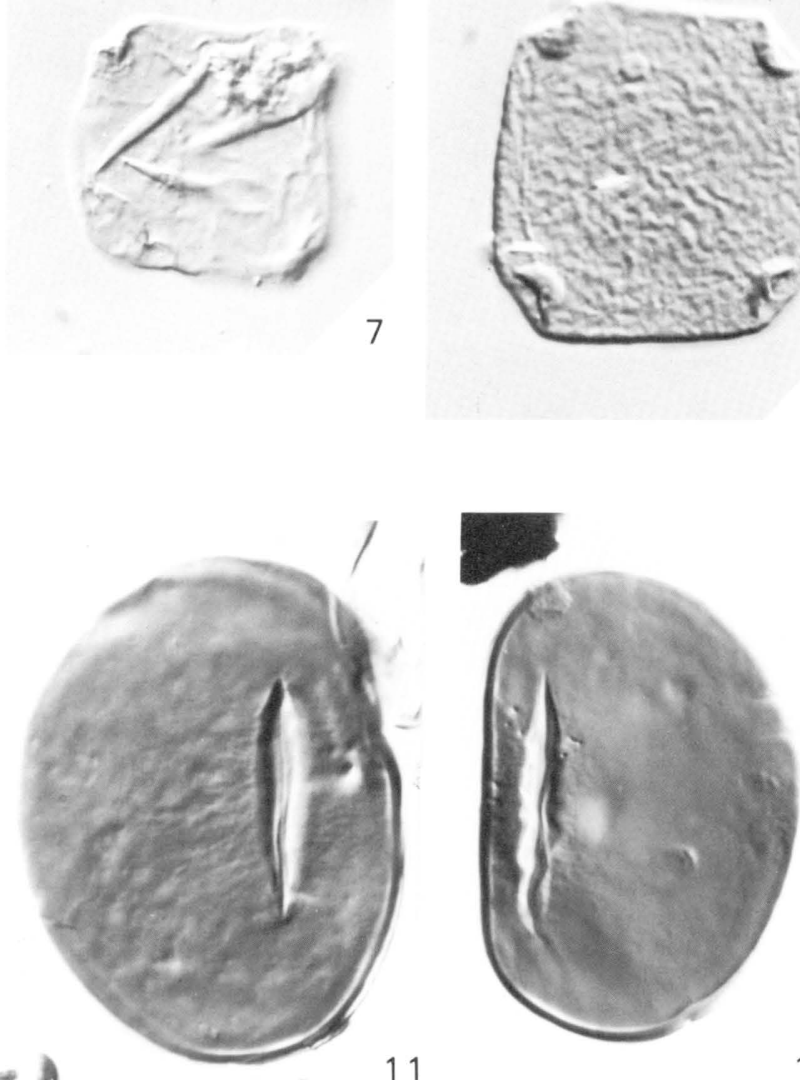

12
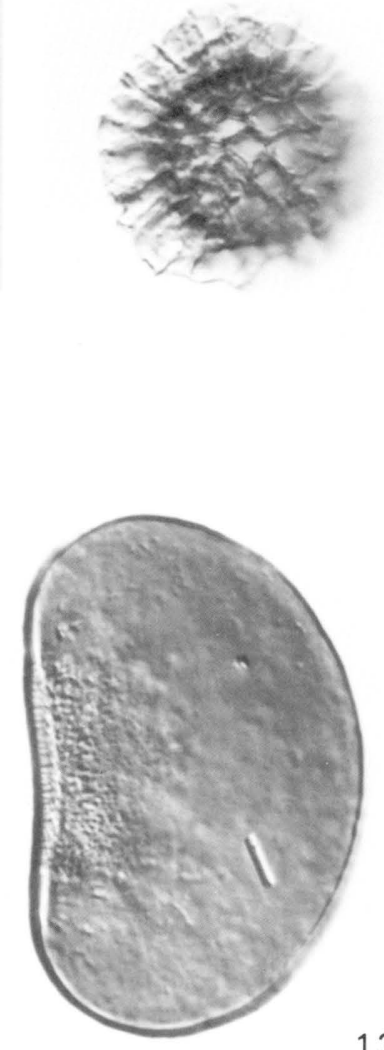

9
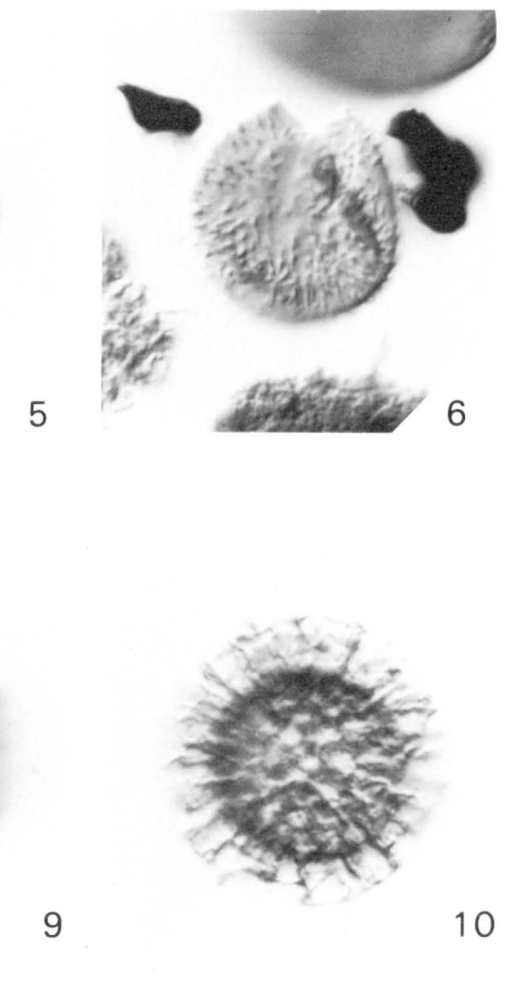

10

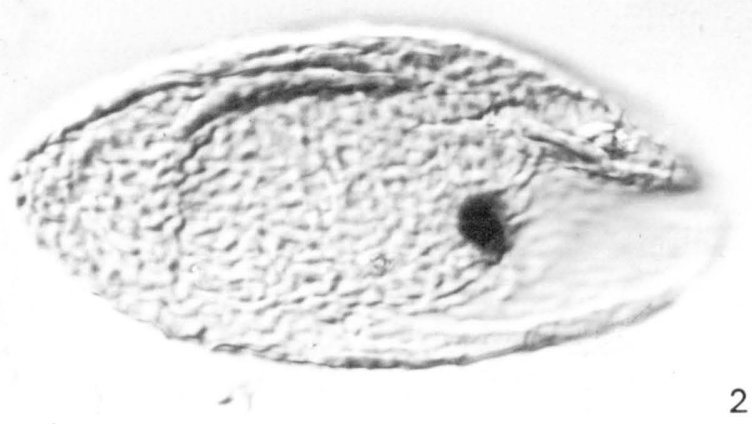

2

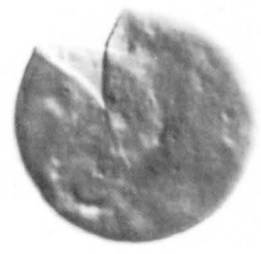

5

6
8

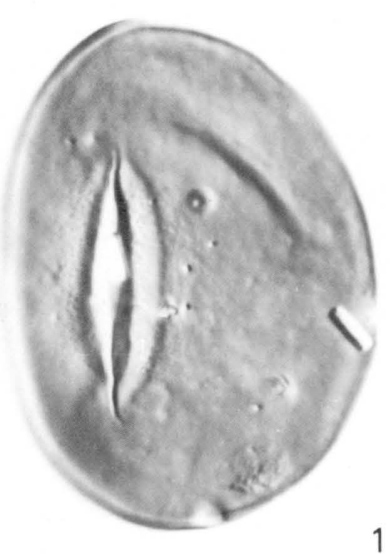

ALGAL CYSTS AND MONOLETE SPORES 
PLATE 2. Monolete and trilete spores

[All specimens $\times 1,000$, except 8 , which is $\times 250$. England Finder coordinates in brackets]

FIGURES 1-5. Laevigatosporites $\mathrm{sp}$. S.

1. Dry Creek, Mont.; slide D7000-B (1) [R37/1].

2. Dry Creek, Mont.; slide D7000-B (1) [R43/2].

3. Reno Creek, Mont.; slide D7411-C (1) [R65/0].

4. Dry Creek, Mont; slide D7000-B (1) [R53/1].

5. Jacobs Coulee, Mont.; slide D6940-AA (1) [H45/2].

6, 7. Reticuloidosporites pseudomurii Elsik.

6. Lance Creek .1, Wyo.; slide D7100-B (1) [P61/2].

7. Dry Creek, Mont.; slide D7000-B (1) [Q65/0].

8-10. Azolla cretacea Stanley.

8. Megaspore, $\times 250$; South Snyder Creek, Wyo.; slide D7422-F (1) [G51/0].

9. Part of megaspore showing glochidia, $\times 1,000$; South Snyder Creek, Wyo.; slide D7422-F (1) [S43/0].

10. Microspore; South Snyder Creek, Wyo.; slide D7422-F (1) [M40/2].

11. Osmundacidites sp. Dry Creek, Mont.; slide D7000-B (1) [O59/O].

12. Cicatricosisporites sp. Dry Creek, Mont.; slide D7000-B (1) [K63/1].

13, 14. Ghoshispora bella (Kondinskaya) Srivastava. Two levels of focus on a single specimen; Lance Creek 1, Wyo.; slide D7100-B (1) [R63/O]. 


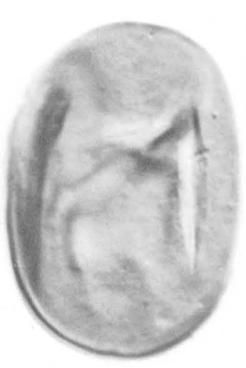

1

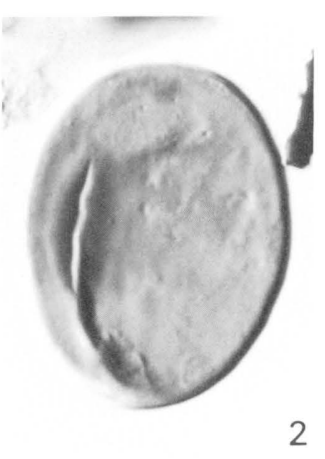

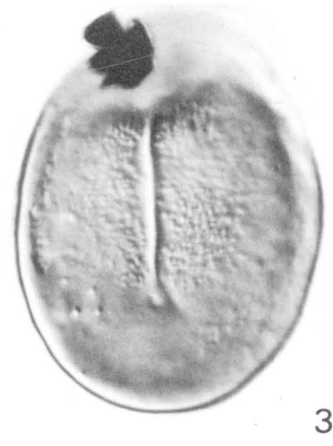
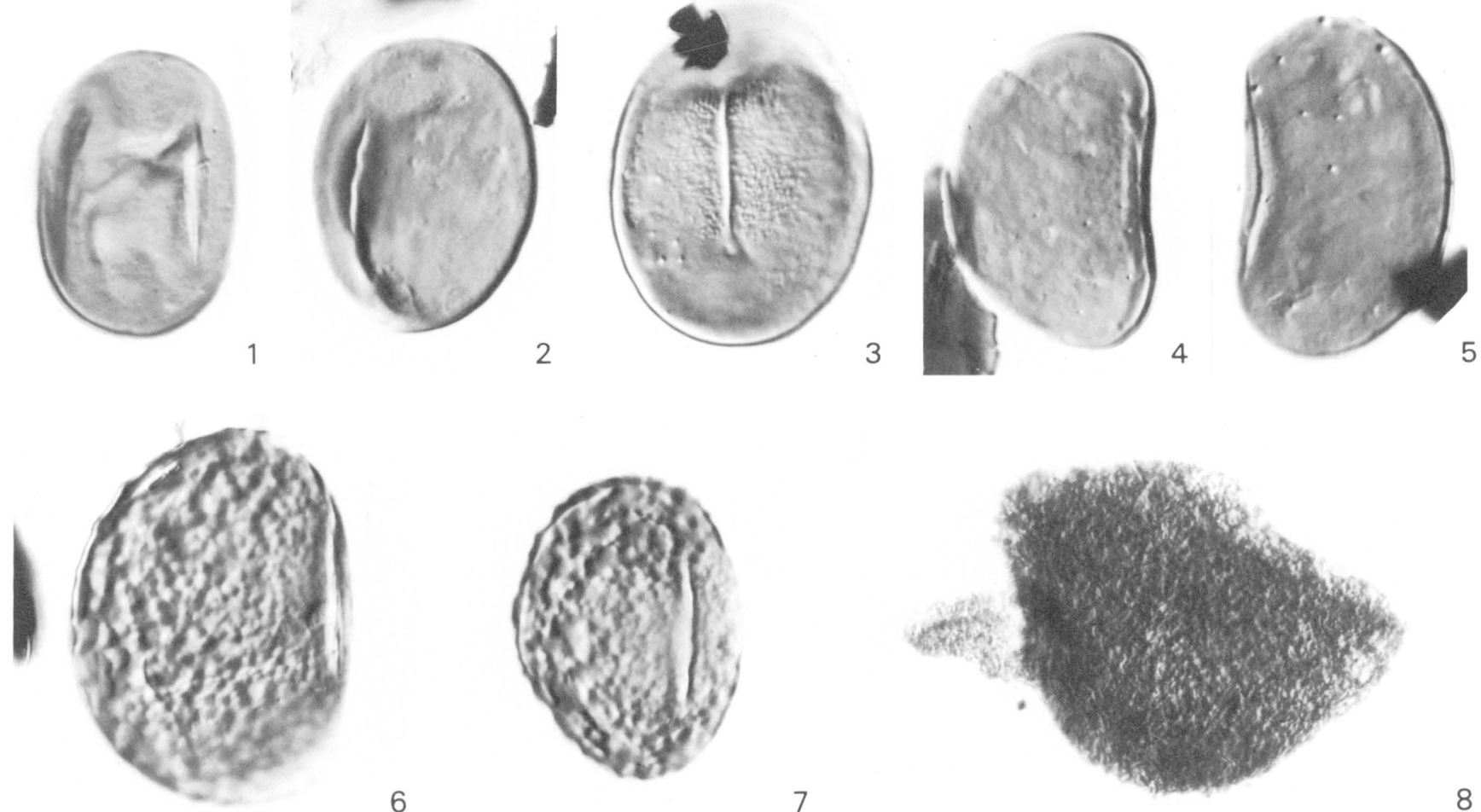

6

7
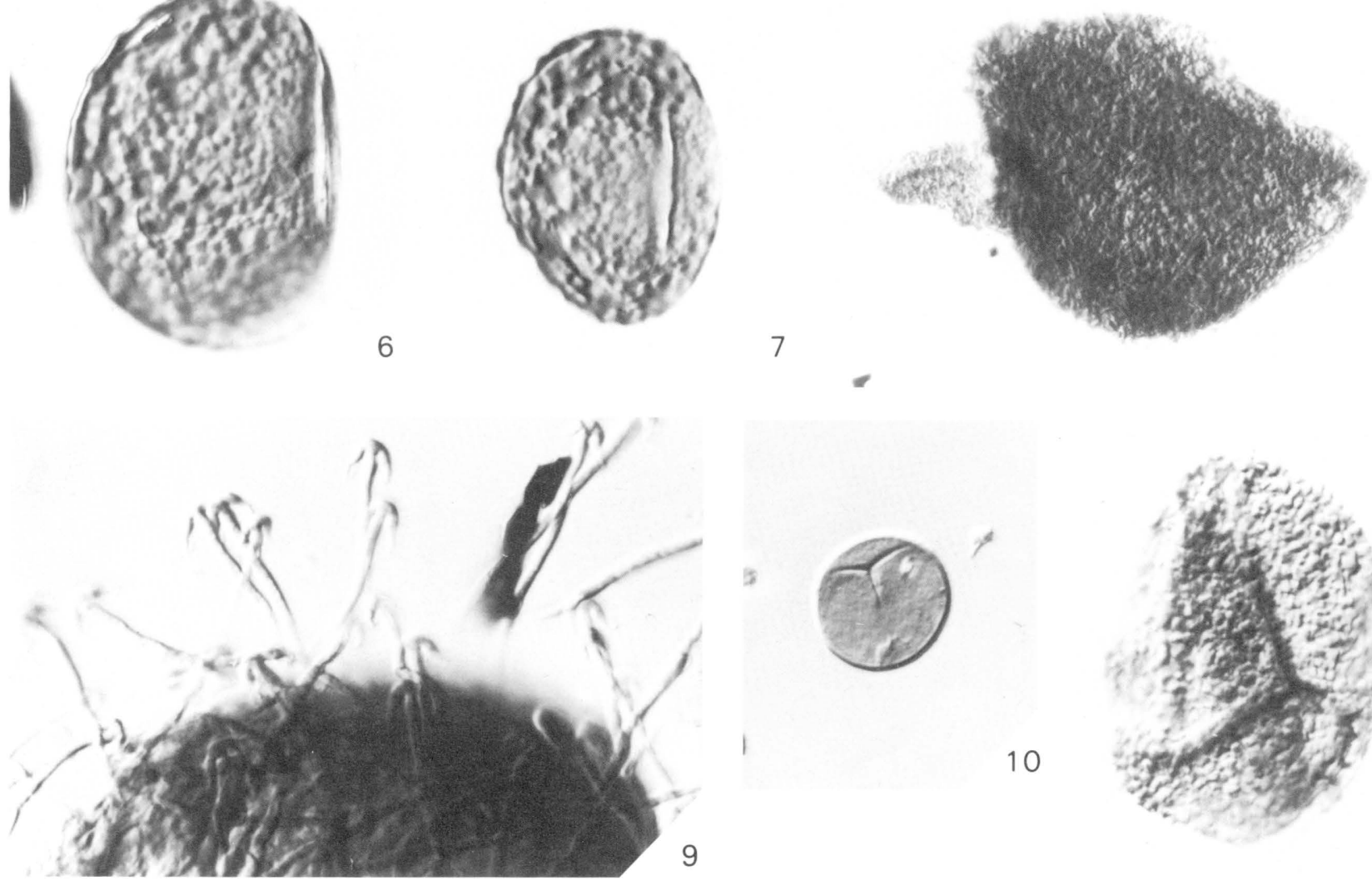

10
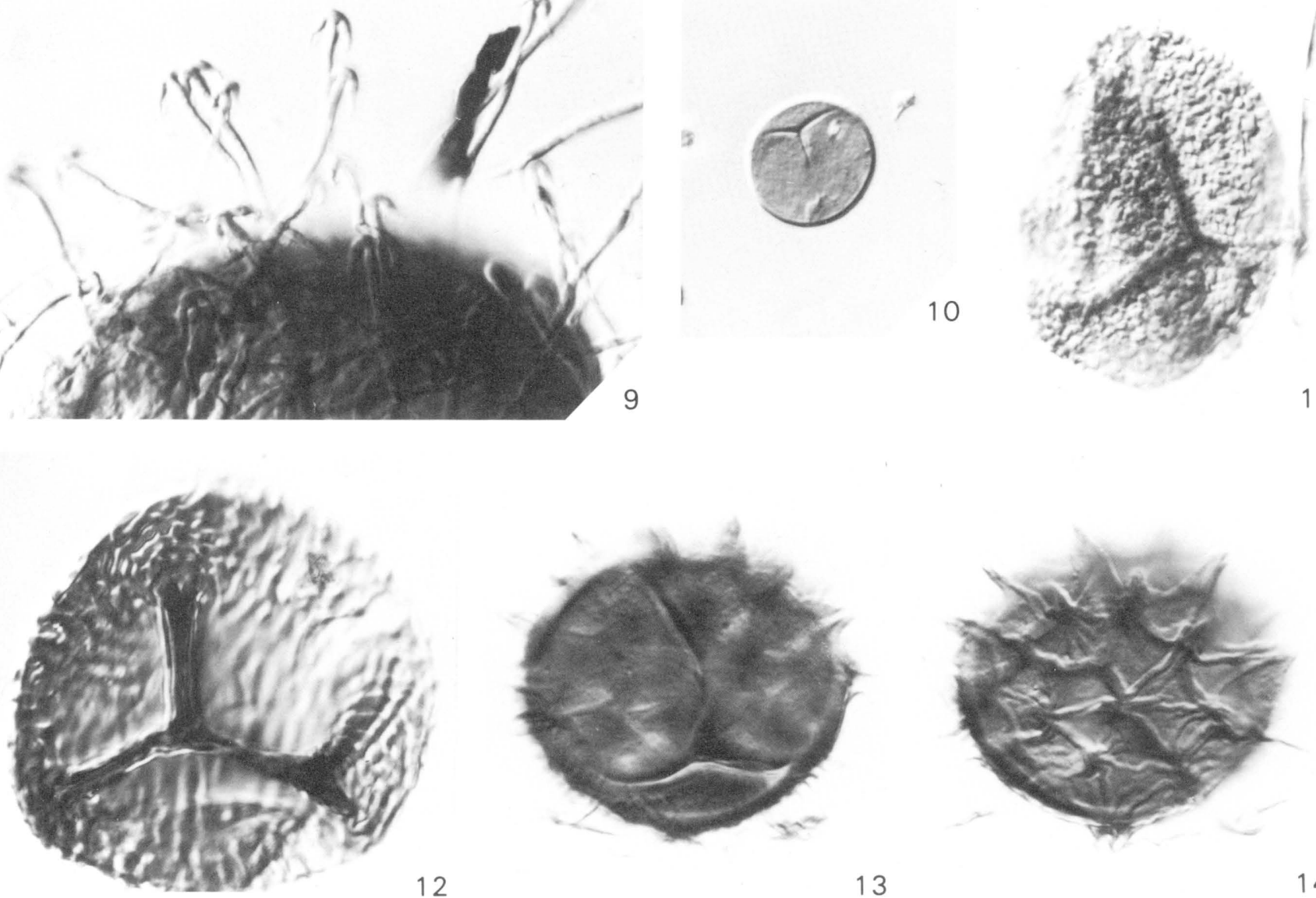

12

13 
PLATE 3. Trilete spores

[All specimens $\times 1,000$. England Finder coordinates in brackets]

FIGURES 1, 2. Ghoshispora bella (Kondinskaya) Srivastava. Two levels of focus on a single specimen; Lance Creek 1, Wyo.; slide D7100-C (1) [K59/1].

3-5. Cyathidites diaphana (Wilson \& Webster) n. comb.

3. Dry Creek, Mont.; slide D7000-B (1) [R47/1].

4. Dry Creek, Mont.; slide D7000-B (1) [O65/O].

5. South Snyder Creek, Wyo.; slide D7422-E (1) [N48/O].

6-8. Gleicheniidites sp. cf. Gleichenia triangula Stanley.

6. Jacobs Coulee, Mont.; slide D6940-AA (1) [R47/1].

7. East Beaver Creek, Mont.; slide D6937-D (1) [O53/O].

8. East Beaver Creek, Mont.; slide D6937-L (1) [O59/O].

9-11. Toroisporis major (Pflug) Stanley.

9. Jacobs Coulee, Mont.; slide D6940-AA (1) [N52/1].

10. Dry Creek, Mont.; slide D7000-B (1) [R45/2].

11. Dry Creek, Mont.; slide D7000-B (1) [J35/2].

12-15. Stereisporites spp.

12. Dry Creek, Mont.; slide D7000-B (1) [H66/1].

13. Jacobs Coulee, Mont.; slide D6940-AA (1) [J44/3].

14. Dry Creek, Mont.; slide D7000-B (1) [G58/4].

15. Sussex, Wyo.; slide D7299-O (1) [K41/2]. 

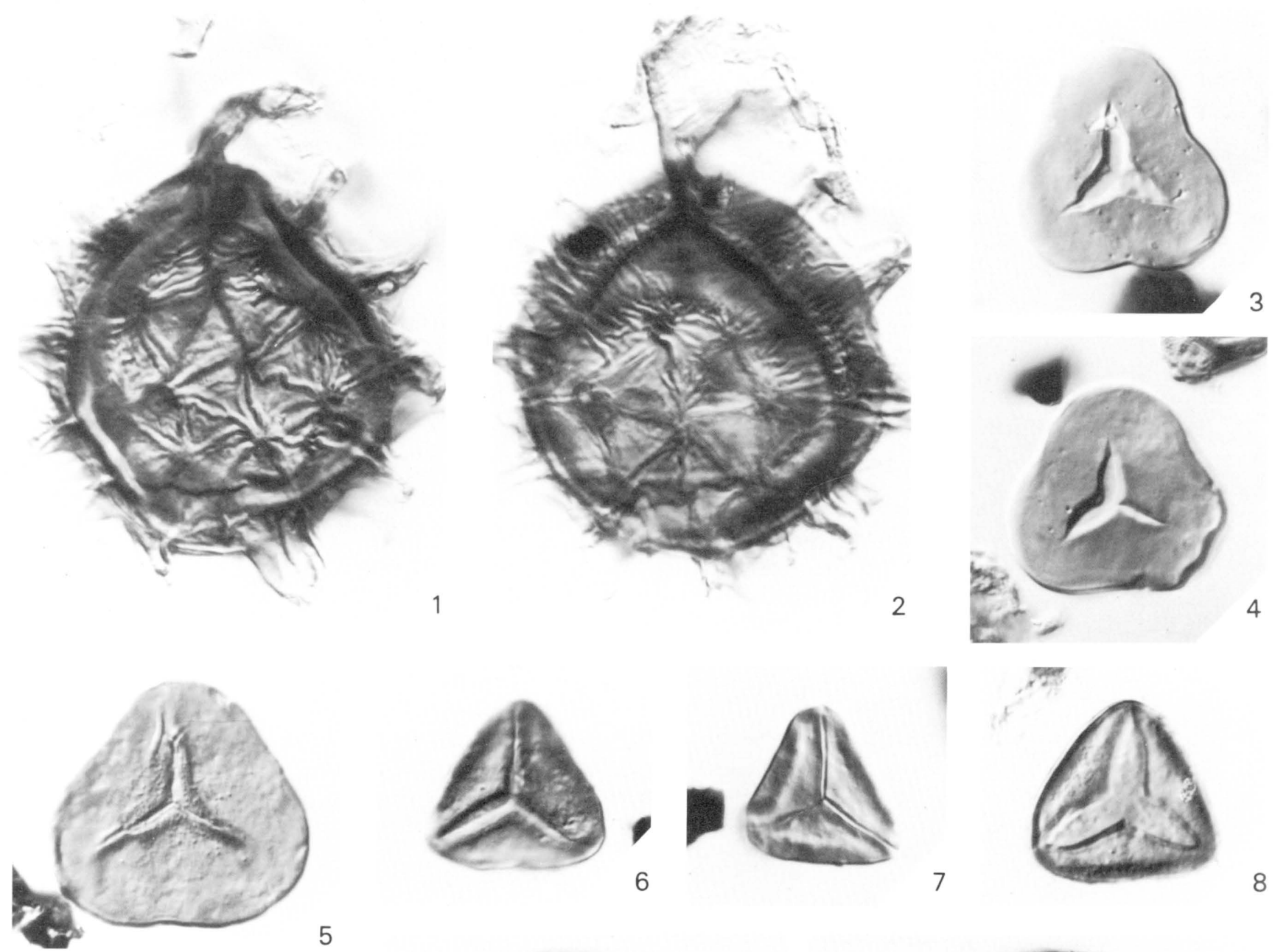

5
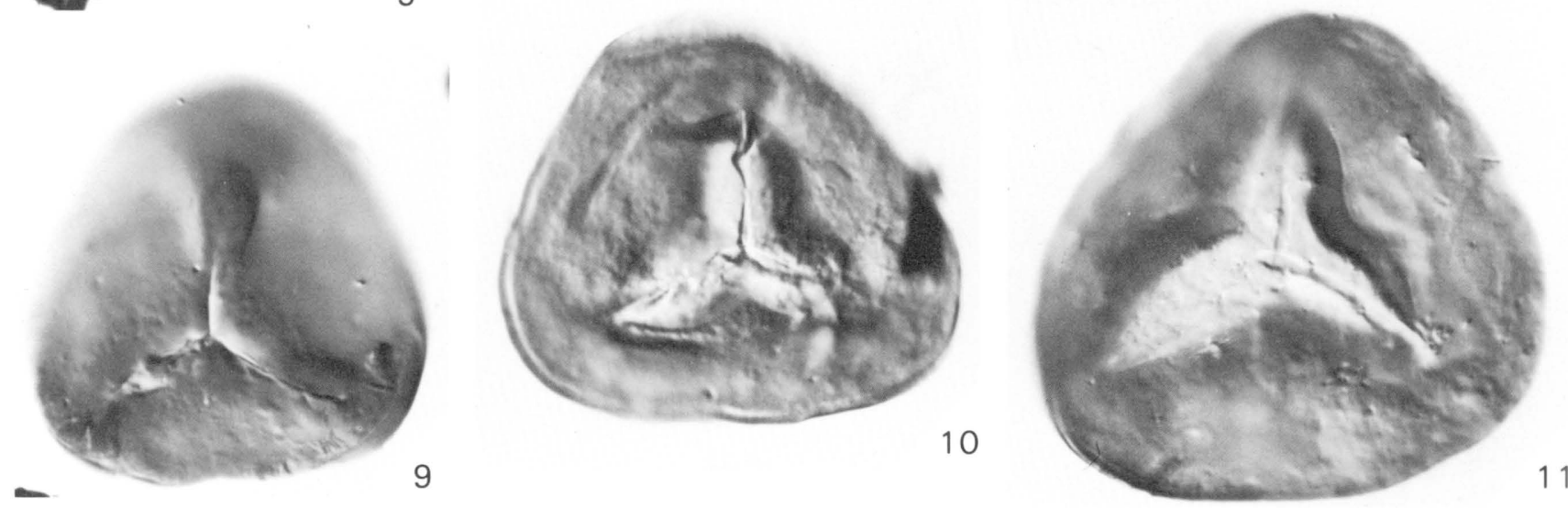

11

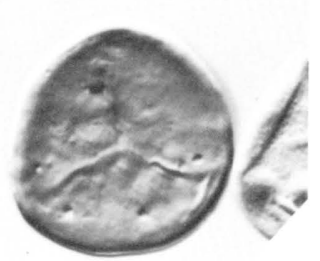

12
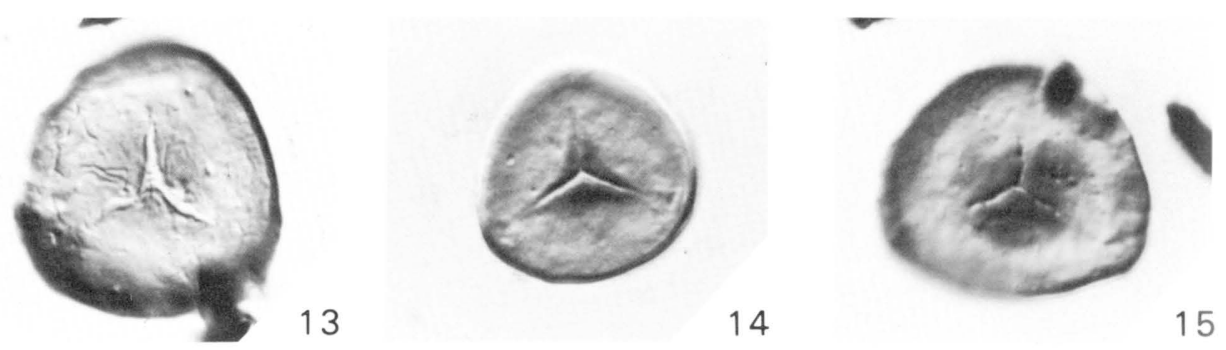

TRILETE SPORES 
PLATE 4. Trilete spores

[All specimens $\times 1,000$. England Finder coordinates in brackets]

FIGURES 1-4. Stereisporites spp.

1. East Beaver Creek, Mont.; slide D6937-L (1) [067/1].

2, 3. Two levels of focus on a single specimen; Dry Creek, Mont;; slide D7000-B (1) [L61/O].

4. Dry Creek, Mont.; slide D7000-B (1) [G42/3].

5, 6. Zlivisporis novomexicanum (Anderson) Leffingwell. Two levels of focus on a single specimen; Lance Creek 1, Wyo.; slide D7100-C (1) [L57/2].

7, 8. Zlivisporis novomexicanum? Two levels of focus on a single specimen; Dry Creek, Mont.; slide D7000-B (1) [H51/4].

9-12. Zlivisporis novomexicanum (Anderson) Leffingwell.

9, 10. Two levels of focus on a single specimen; Dry Creek, Mont.; slide D7000-B (1) [M59/3].

11, 12. Two levels of focus on a single specimen; Lance Creek 1, Wyo.; slide D7100-C (1) [Q40/2].

13. Zlivisporis novomexicanum? Lance Creek 1, Wyo.; slide D7100-C (1) [L46/1]. 

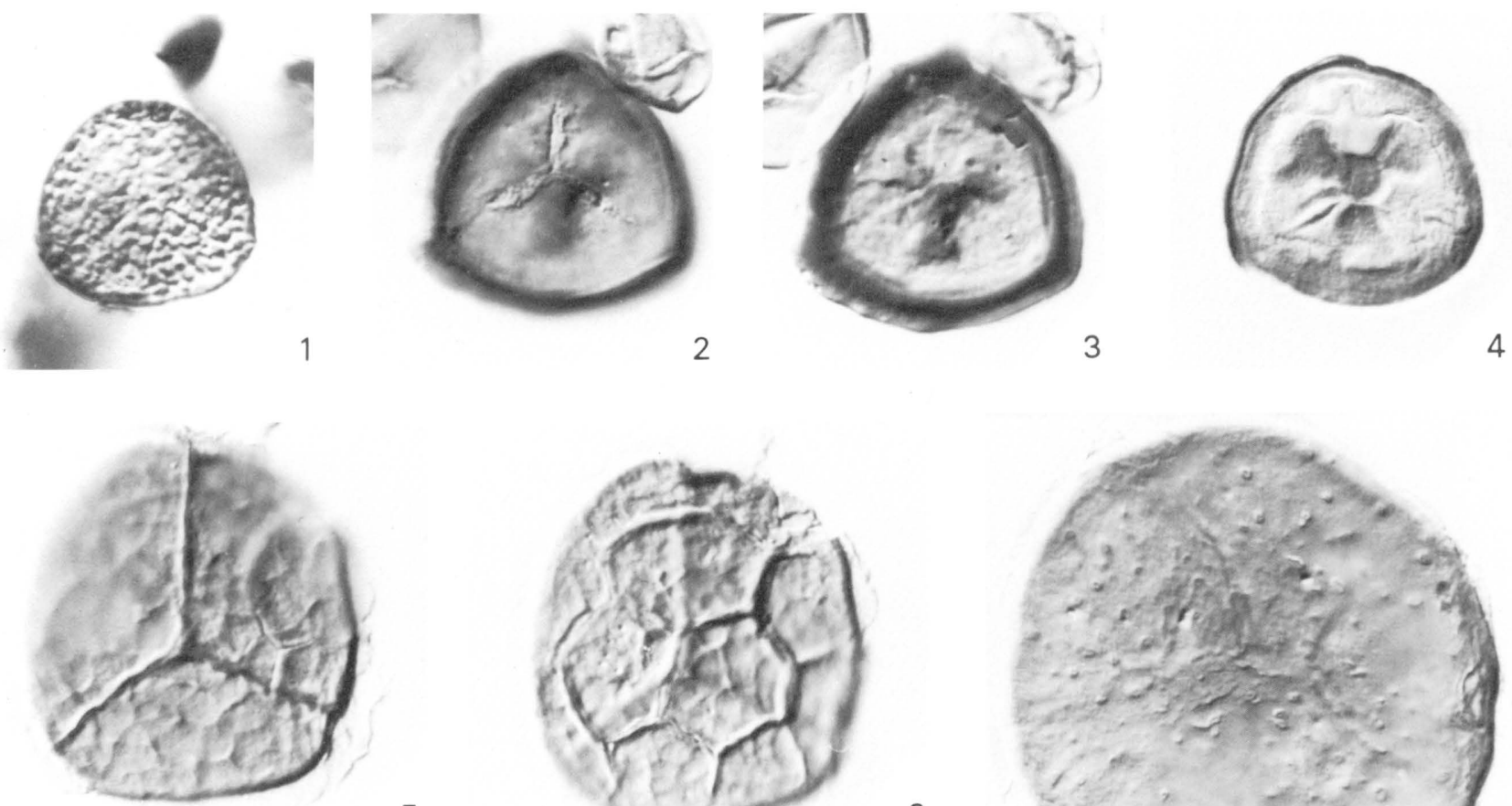

5
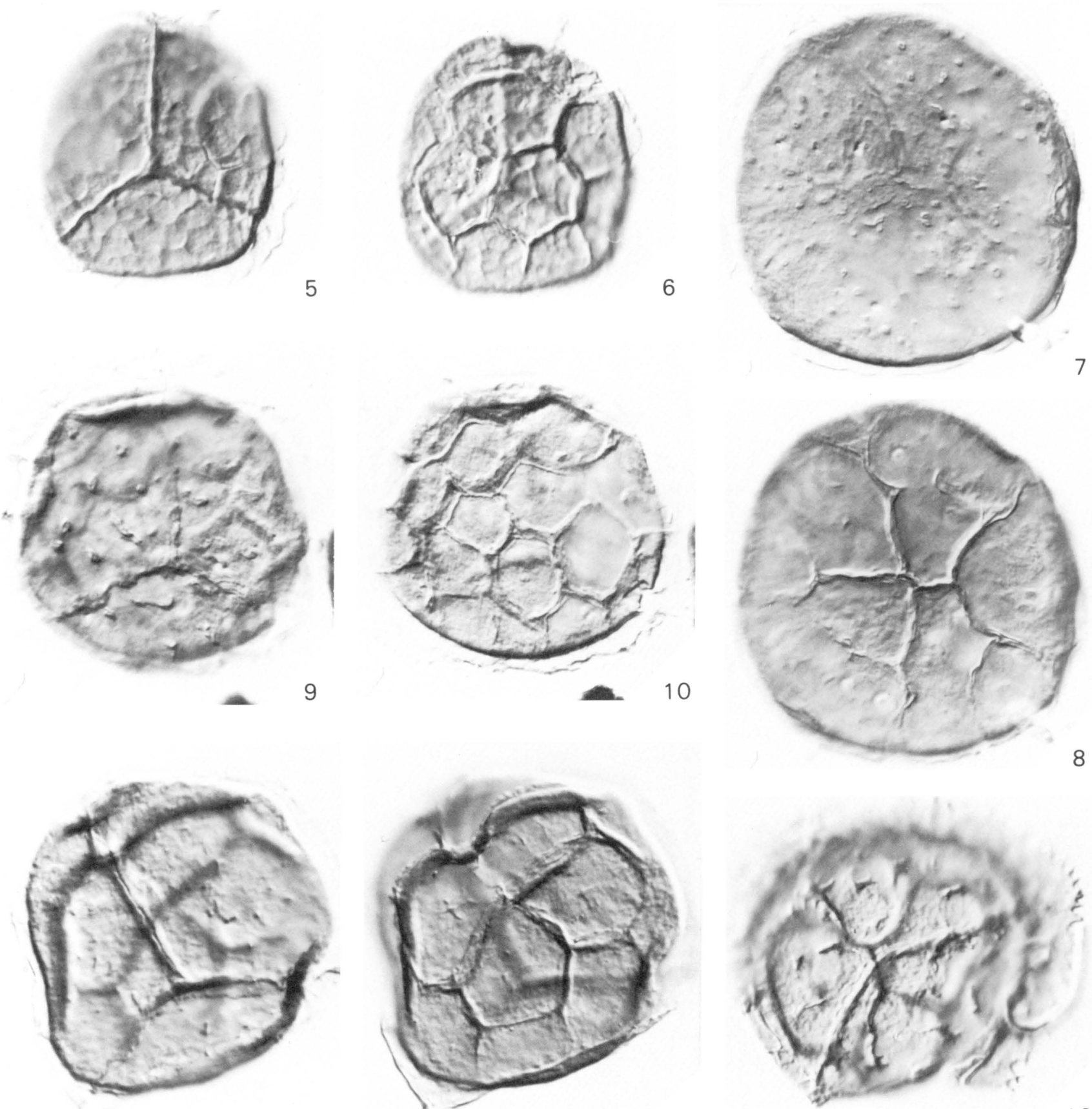

11
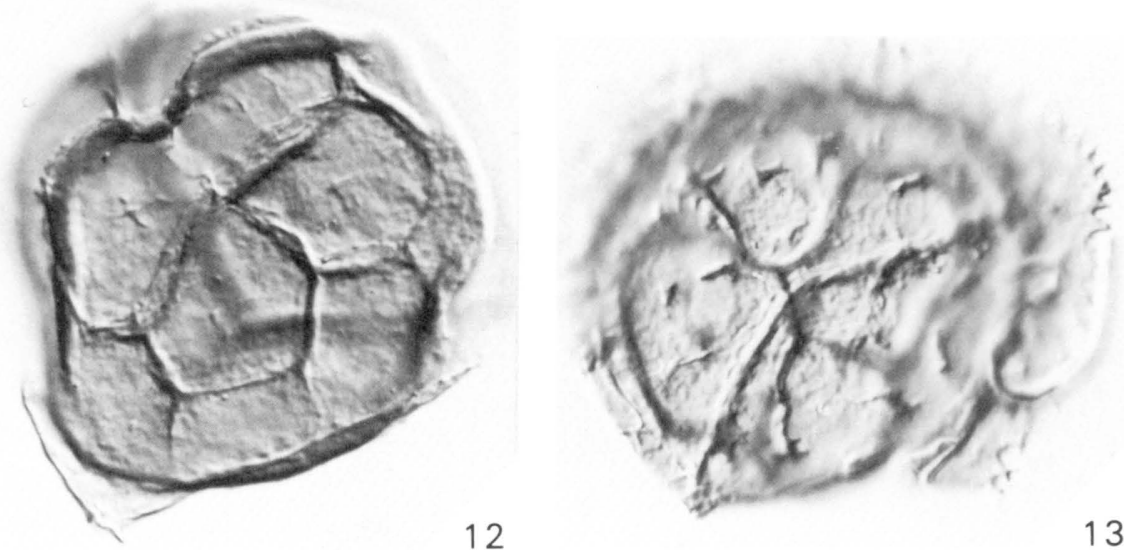

TRILETE SPORES 
PLATE 5. Gymnosperm pollen

[All specimens $\times 1,000$. England Finder coordinates in brackets]

FIGURE 1. Araucariacites sp. Reno Creek, Mont.; slide D7411-C (1) [Q58/1].

2, 3. Corollina sp.

2. Lance Creek 1, Wyo.; slide D7100-C (1) [P44/O].

3. Lance Creek 1, Wyo.; slide D7100-C (1) [J57/1].

4. Cycadopites scabratus Stanley. East Beaver Creek, Mont.; slide D6937-K (1) [Q50/O].

5, 6. Taxodiaceaepollenites hiatus (Potonié) Kremp.

5: Dry Creek, Mont.; slide D7000-B (1) [P45/O].

. 6. Cow Creek, Wyo.; slide D7419 (1) [P55/2].

7-10. Pityosporites spp.

7. East Beaver Creek, Mont.; slide D6937-K (1) [M64/1].

8, 9. Two levels of focus on a single specimen; South Snyder Creek, Wyo.; slide D7422-F (1) [O50/3].

10. East Beaver Creek, Mont.; slide D6937-H (1) [J60/O].

11. Pityosporites? sp. Specimen possibly closer to Cedrus than to Pinus in botanical affinity; Dry Creek, Mont.; slide D7000-B (1) [H54/O]. 

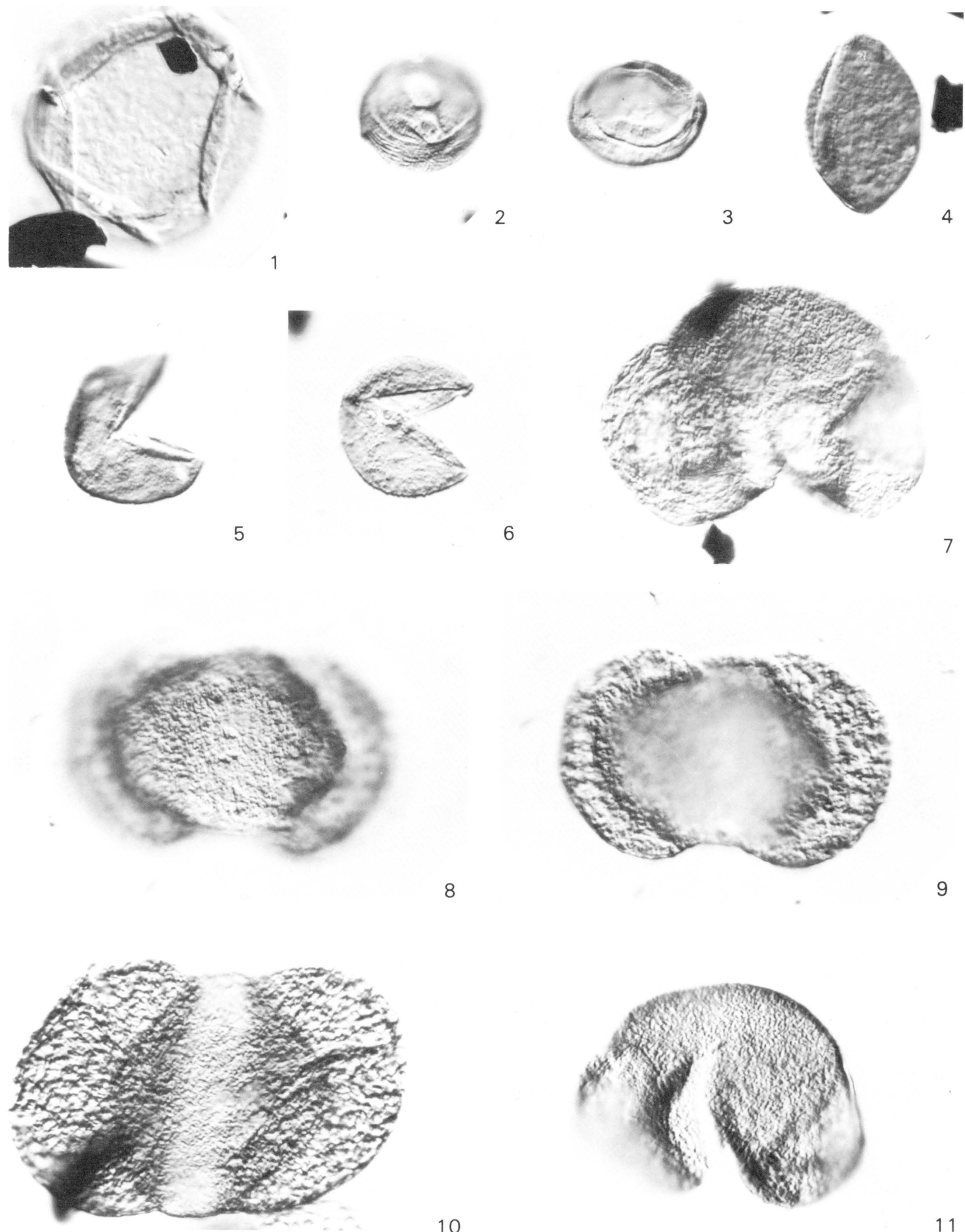

GYMNOSPERM POLLEN 
PLATE 6. Gymnosperm pollen and monosulcate and tricolpate angiosperm pollen

[All specimens $\times 1,000$. England Finder coordinates in brackets]

FIGURES 1,2. Pityosporites? sp. Two levels of focus on a single haploxylonoid specimen; Cow Creek, Wyo.; slide D7419 (1) [L66/2].

3. Podocarpidites maximus (Stanley) Norton \& Hall. East Beaver Creek, Mont.; slide D6937-K (1) [N35/2].

4-7. Arecipites tenuiexinous Leffingwell.

4. East Beaver Creek, Mont.; slide D6937-K (1) [R54/2].

5. South Snyder Creek, Wyo.; slide D7422-E (1) [K45/O].

6. East Beaver Creek, Mont.; slide D6937-K (1) [N43/2].

7. East Beaver Creek, Mont.; slide D6937-K (1) [O44/1].

8. Liliacidites leei Anderson. East Beaver Creek, Mont.; slide D6937-D (1) [P55/2].

9-11. Discoidites parvistriatus (Norton) n. comb.

9. East Beaver Creek, Mont.; slide D6937-K (1) [N66/O].

10. East Beaver Creek, Mont.; slide D6937-K (1) [Q36/2].

11. South Snyder Creek, Wyo.; slide D7422-F (1) [O40/2].

12-16. Fraxinoipollenites variabilis Stanley.

12. Polar view; Lance Creek 2, Wyo.; slide D7137-I (1) [O71/O].

13. Equatorial view; Lance Creek 2, Wyo.; slide D7137-I (1) [Q47/2].

14. Equatorial view; Lance Creek 2, Wyo.; slide D7137-I (1) [Q71/1].

15. Equatorial view; Lance Creek 2, Wyo.; slide D7137-I (1) [P47/4].

16. Equatorial view; Lance Creek 2, Wyo.; slide D7137-I (1) [R43/O].

17, 18. Quercoidites spissus Leffingwell.

17. Jacobs Coulee, Mont.; slide D6940-F (1) [R36/2].

18. Questionably identified specimen; East Beaver Creek, Mont.; slide D6937-D (1) [L44/O].

19-21. Retitrescolpites anguloluminosus (Anderson) Frederiksen.

19. Equatorial view; Cow Creek, Wyo.; slide D7419 (1) [S68/O].

20. Polar view; Leverett Butte, Wyo.; slide D7421-D (1) [Q63/2].

21. Polar view; Leverett Butte, Wyo.; slide D7421-D (1) [N50/1]. 

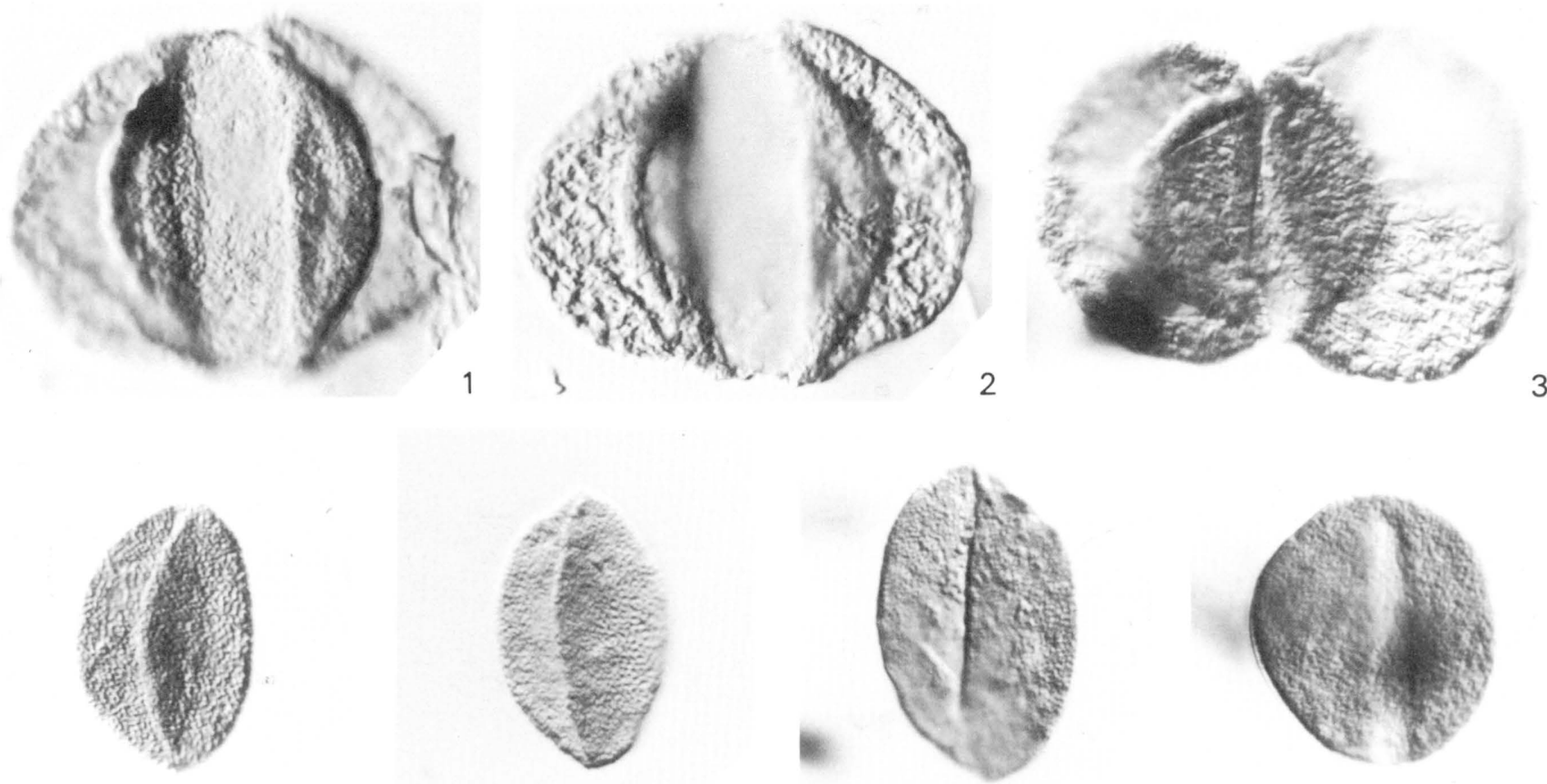

4

5

6
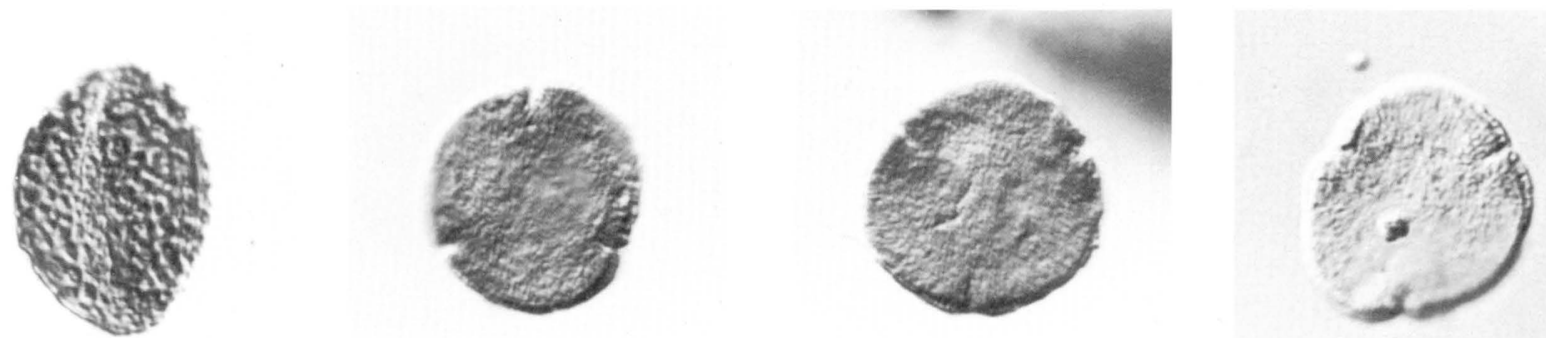

8

10
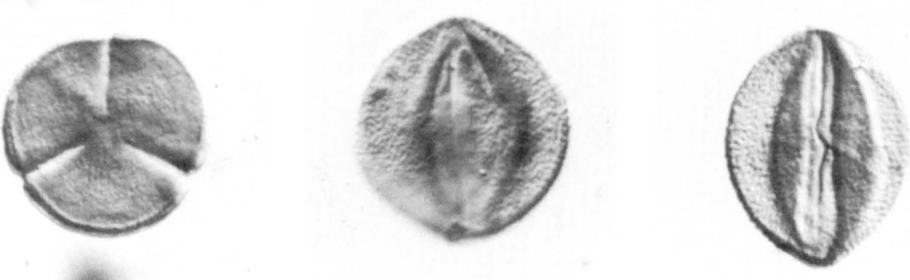

13

14
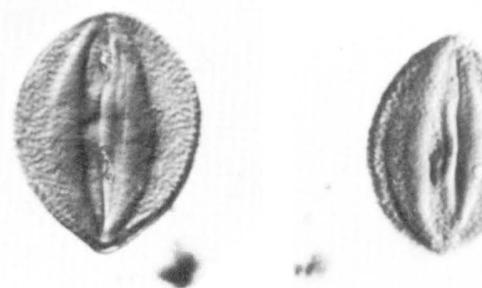

15
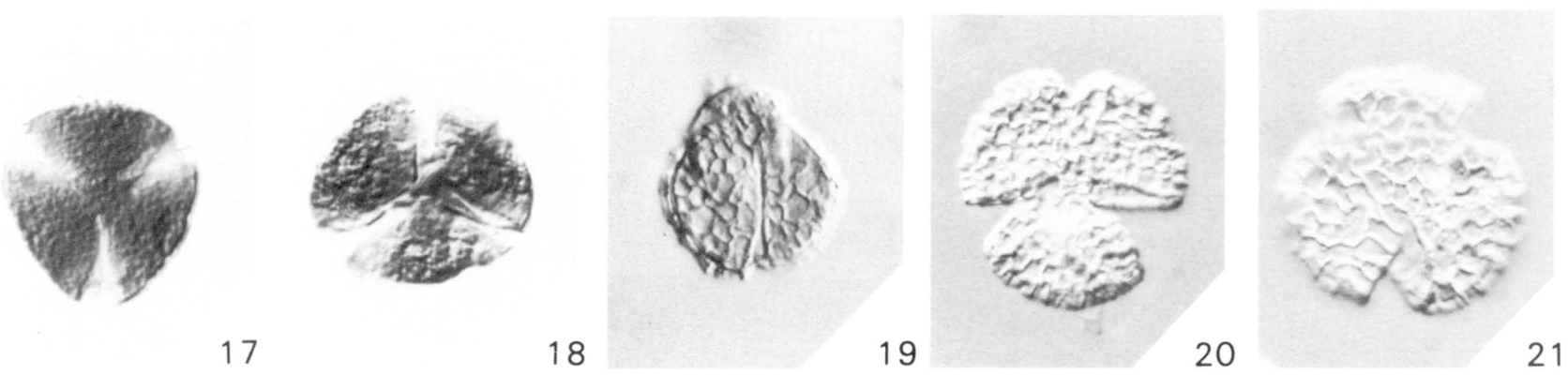

GYMNOSPERM POLLEN AND MONOSULCATE AND TRICOLPATE ANGIOSPERM POLLEN 
PLATE 7. Tricolpate and tricolporate angiosperm pollen

[All specimens $\times 1,000$. England Finder coordinates in brackets]

FIGURES 1, 2. Rousea spp.

1. Dry Creek, Mont.; slide D7000-B (1) [H64/4].

2. Jacobs Coulee, Mont.; slide D6940-AA (1) [S39/2].

3, 4. Striatopollis tectatus Leffingwell.

3. Polar view; Dry Creek, Mont.; slide D7000-B (1) [N59/2].

4. Equatorial view; Jacobs Coulee, Mont.; slide D6940-AA (1) [R64/O].

5-7. Tricolpites hians Stanley.

5. Polar view; Dry Creek, Mont.; slide D7000-B (1) [K40/O].

6 , 7. Two levels of focus on a single specimen in equatorial view; Dry Creek, Mont.; slide D7000-B (1) [K57/O].

8-12. Tricolpites spp.

8. East Beaver Creek, Mont.; slide D6937-D (1) [O52/O].

9. Reno Creek, Mont.; slide D7411-C (1) [F44/1].

10. Jacobs Coulee, Mont.; slide D6940-AA (1) [R42/O].

11. Jacobs Coulee, Mont.; slide D6940-AA (1) [S34/2].

12. East Beaver Creek, Mont.; slide D6937-D (1) [P64/3].

13, 14. Brevicolporites colpella Anderson.

13. Leverett Butte, Wyo.; slide D7421-E (1) [H55/4].

14. Leverett Butte, Wyo.; slide D7421-E (1) [S47/2].

15-17. Kurtzipites circularis (Norton) Srivastava.

15. Lance Creek 2; Wyo.; slide D7137-E (1) [S61/O].

16. Cow Creek, Wyo.; slide D7419 (1) [O51/1].

17. Cow Creek, Wyo.; slide D7419 (1) [P50/1].

18, 19. Kurtzipites trispissatus Anderson.

18. Dry Creek, Mont.; slide D7000-B (1) [J62/2].

19. Dry Creek, Mont.; slide D7000-B (1) [P39/2].

20, 21. Nyssapollenites spp.

20. Dry Creek, Mont.; slide D7000-B (1) [N54/2].

21. Dry Creek, Mont.; slide D7000-B (1) [R60/2].

22-24. Rhoipites sp.

22. Dry Creek, Mont.; slide D7000-B (1) [R46/2].

23, 24. Two levels of focus on a single specimen; Jacobs Coulee, Mont.; slide D6940-AA (1) [H44/1]. 


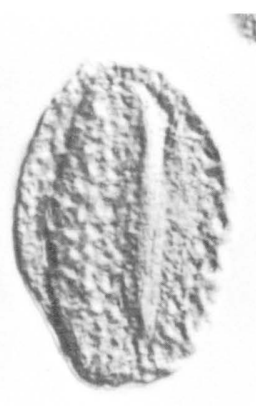

स्स

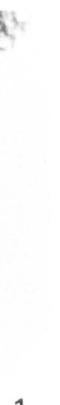

1

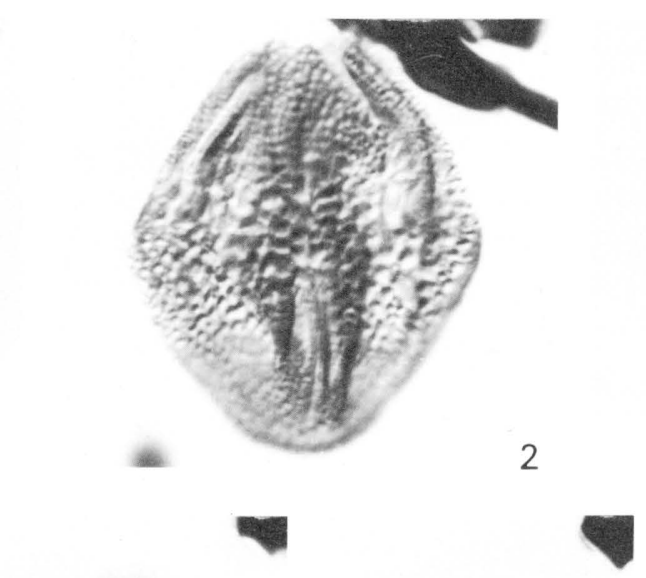

2

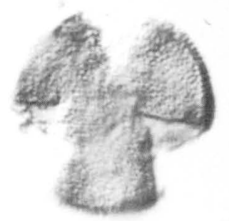

5
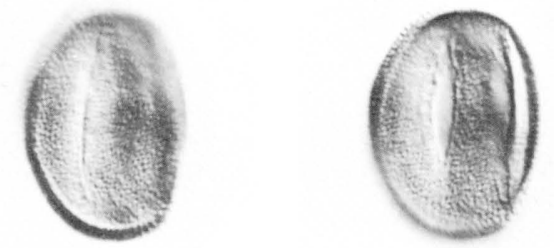

6
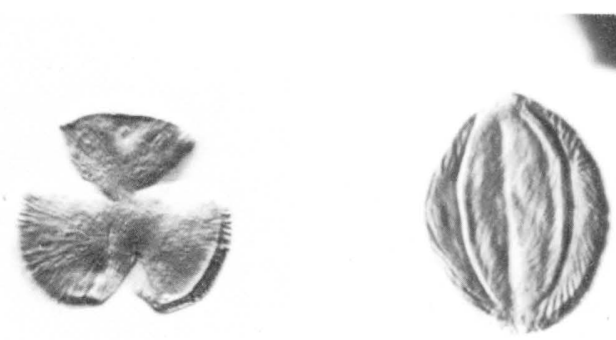

3
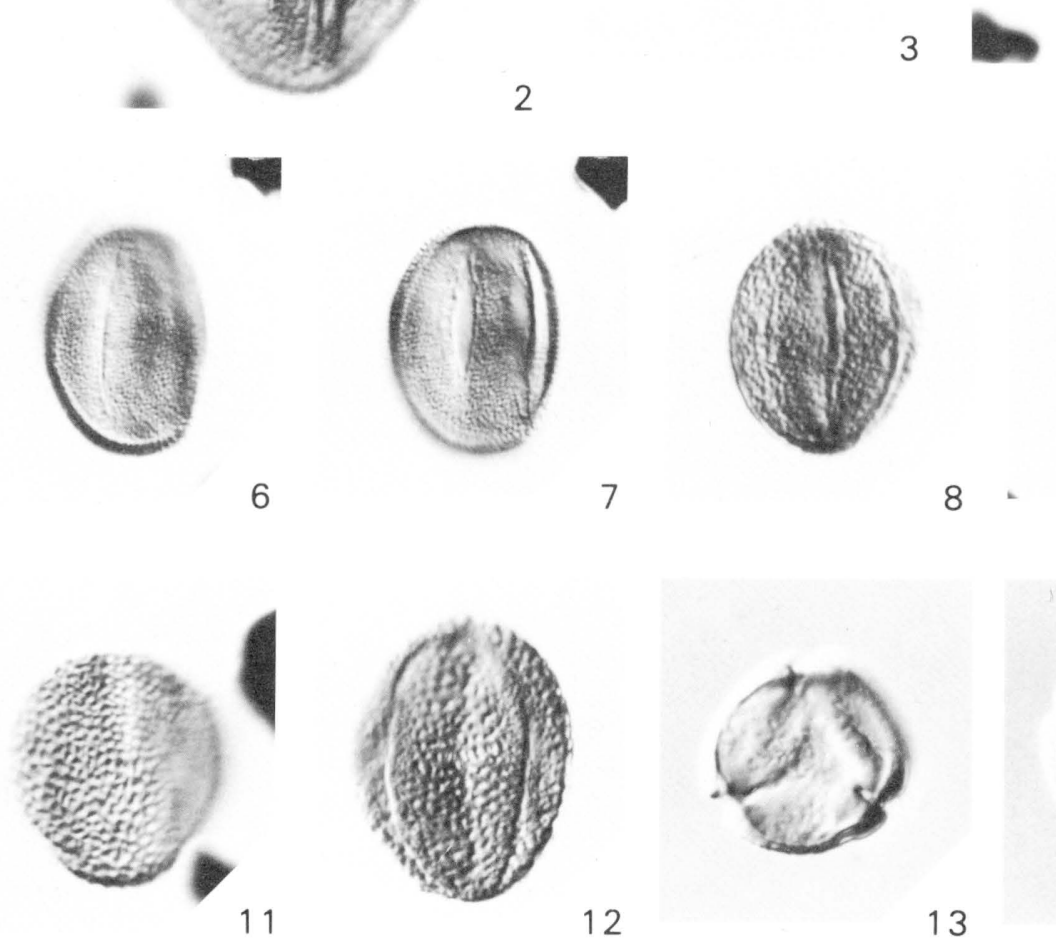

8
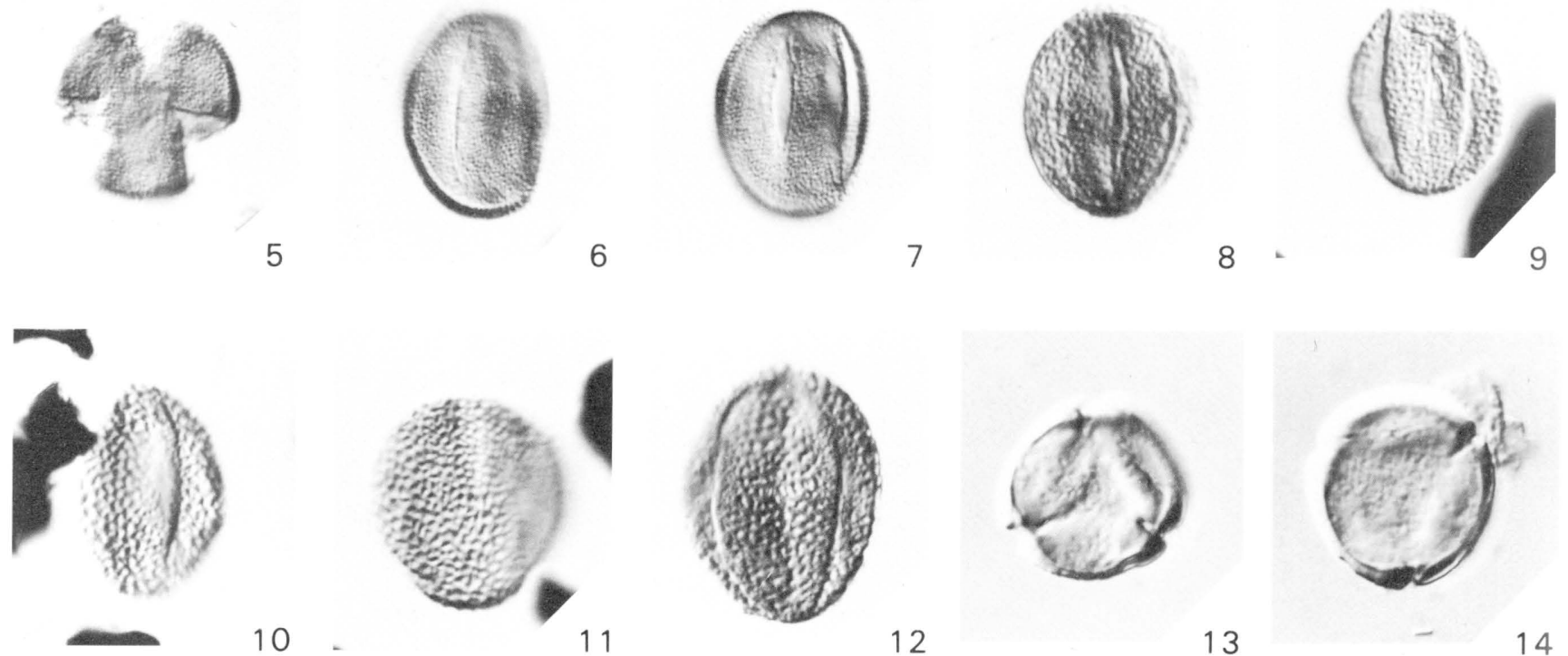

12

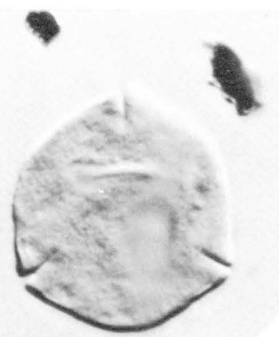

16

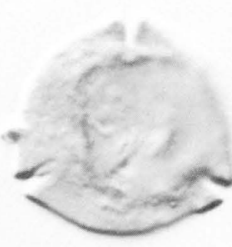

17

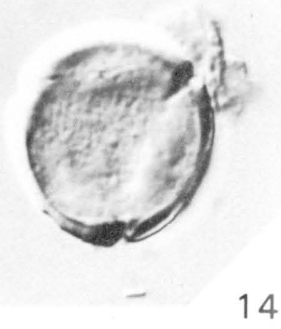

13

14
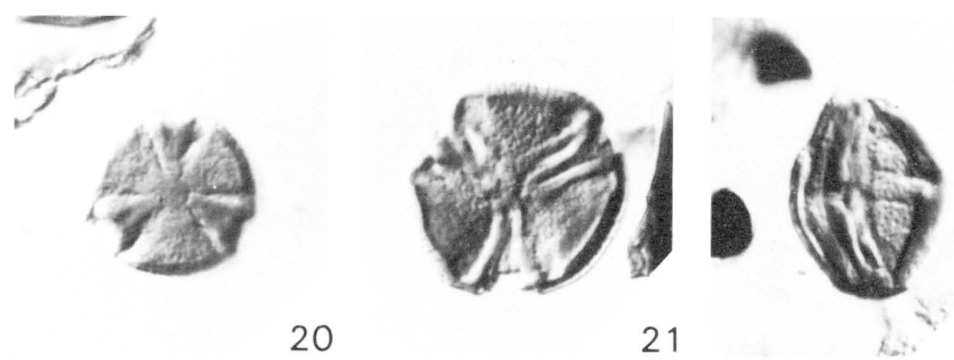

20

22
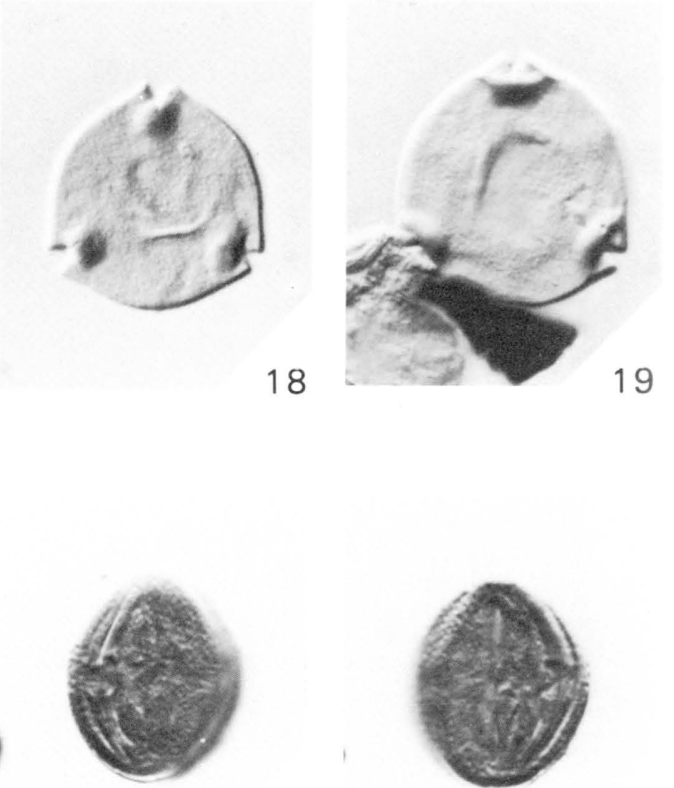

23

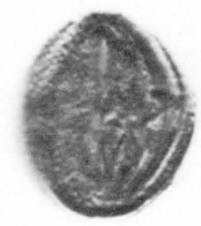

24

TRICOLPATE AND TRICOLPORATE ANGIOSPERM POLLEN 
PLATE 8. Tricolporate, syncolporate, monoporate, and triporate angiosperm pollen.

[All specimens $\times 1,000$. England Finder coordinates in brackets]

FIGURES 1, 2. Tilia vescipites Wodehouse. Two levels of focus on a single specimen; East Beaver Creek, Mont.; slide D6937-K (1) [N58/O].

3, 4. Syncolporites minimus Leffingwell.

3. Dry Creek, Mont.; slide D7000-B (1) [F51/3].

4. Dry Creek, Mont.; slide D7000-B (1) [P40/O].

5, 6. Cupanieidites inaequalis Leffingwell.

5. Specimen showing polar island; Dry Creek, Mont.; slide D7000-B (1) [M61/1].

6. Specimen without polar island; Dry Creek, Mont.; slide D7000-B (1) [P47/2].

7-9. Pandaniidites typicus (Norton) Sweet.

7. Dry Creek, Mont.; slide D7000-B (1) [J45/2].

8. Dry Creek, Mont.; slide D7000-B (1) [N44/2].

9. Dry Creek, Mont.; slide D7000-B (1) [R36/2].

10-12. Sparganiaceaepollenites sp. cf. Sparganium globites Wilson \& Webster.

10, 11. Two levels of focus on a single specimen; East Beaver Creek, Mont.; slide D6937-K (1) [K46/1].

12. Cow Creek, Wyo.; slide D7419 (1) [O46/2].

13. Momipites inaequalis Anderson. Sussex, Wyo.; slide D7299-O (1) [F60/4].

14. Momipites leffingwellii Nichols \& Ott. Leverett Butte, Wyo.; slide D7421-D (1) [L51/4].

15, 16. Momipites tenuipolus Anderson.

15. Leverett Butte, Wyo.; slide D7421-D (1) [M62/2].

16. Leverett Butte, Wyo.; slide D7421-D (1) [M62/2].

17. Momipites waltmanensis Nichols \& Ott. Leverett Butte, Wyo.; slide D7421-D (1) [R40/O].

18. Momipites wyomingensis Nichols \& Ott. Leverett Butte, Wyo.; slide D7421-D (1) [N63/2].

19. Thomsonipollis magnificus (Thomson \& Pflug) Krutzsch. Leverett Butte, Wyo.; slide D7421-D (1) [Q42/4].

20. Triatriopollenites granulatus (Simpson) Leffingwell. Leverett Butte, Wyo.; slide D7421-D (1) [P64/2].

21-23. Triporopollenites plektosus Anderson.

21. Polar view; Lance Creek 1, Wyo.; slide D7100-C (1) [Q51/O].

22. Folded specimen in polar view; Dry Creek, Wyo.; slide D7000-B (1) [H63/4].

23. Equatorial view; Dry Creek, Wyo.; slide D7000-B (1) [G54/1]. 

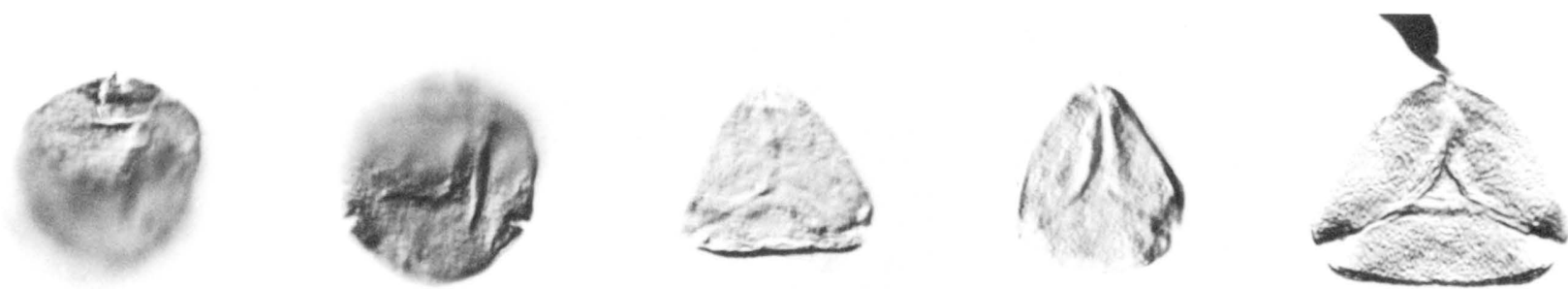

+ 1
$-\quad 1$

2
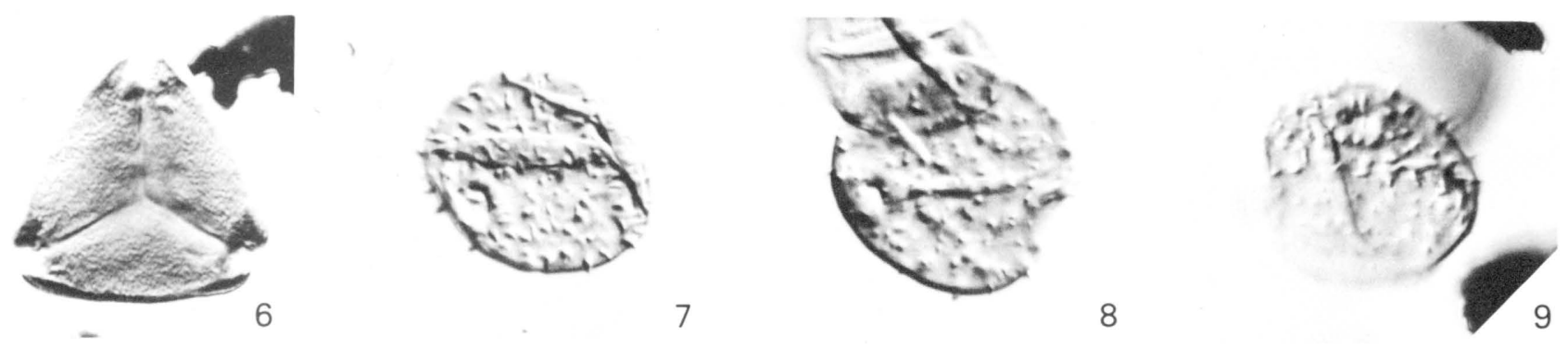

4
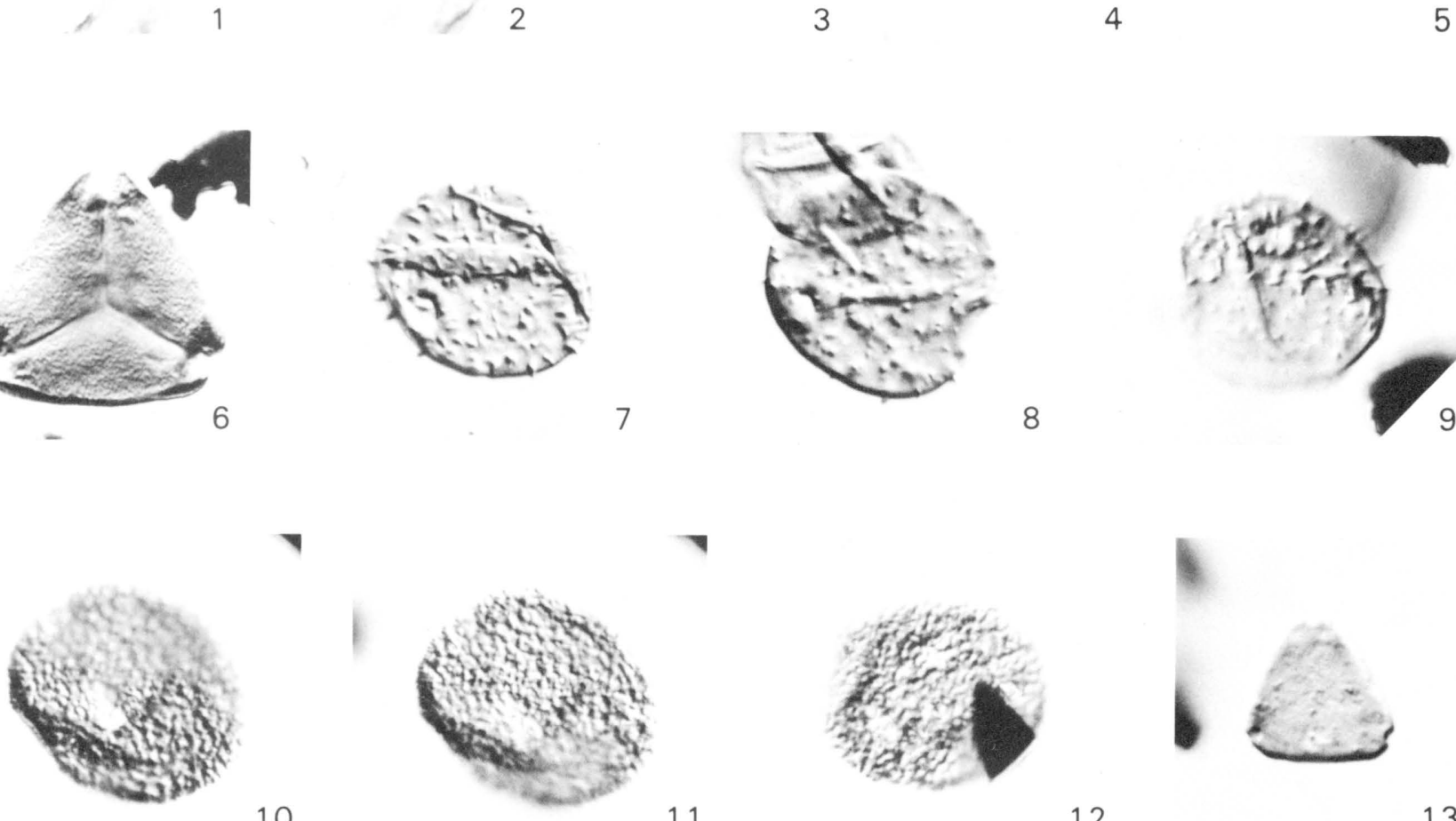

、

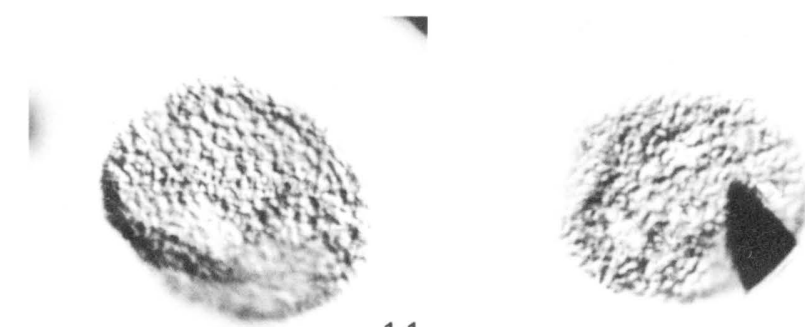

11

12

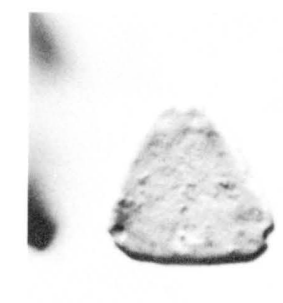

13
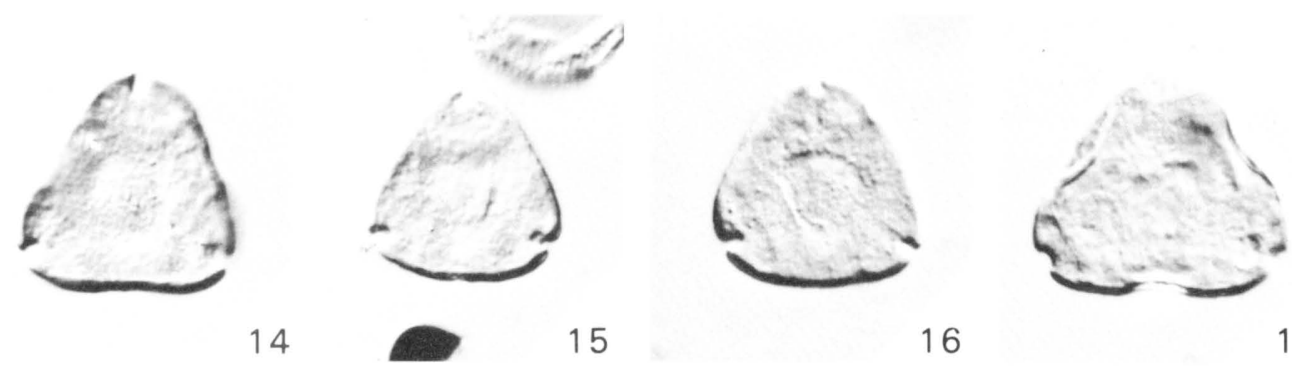

17
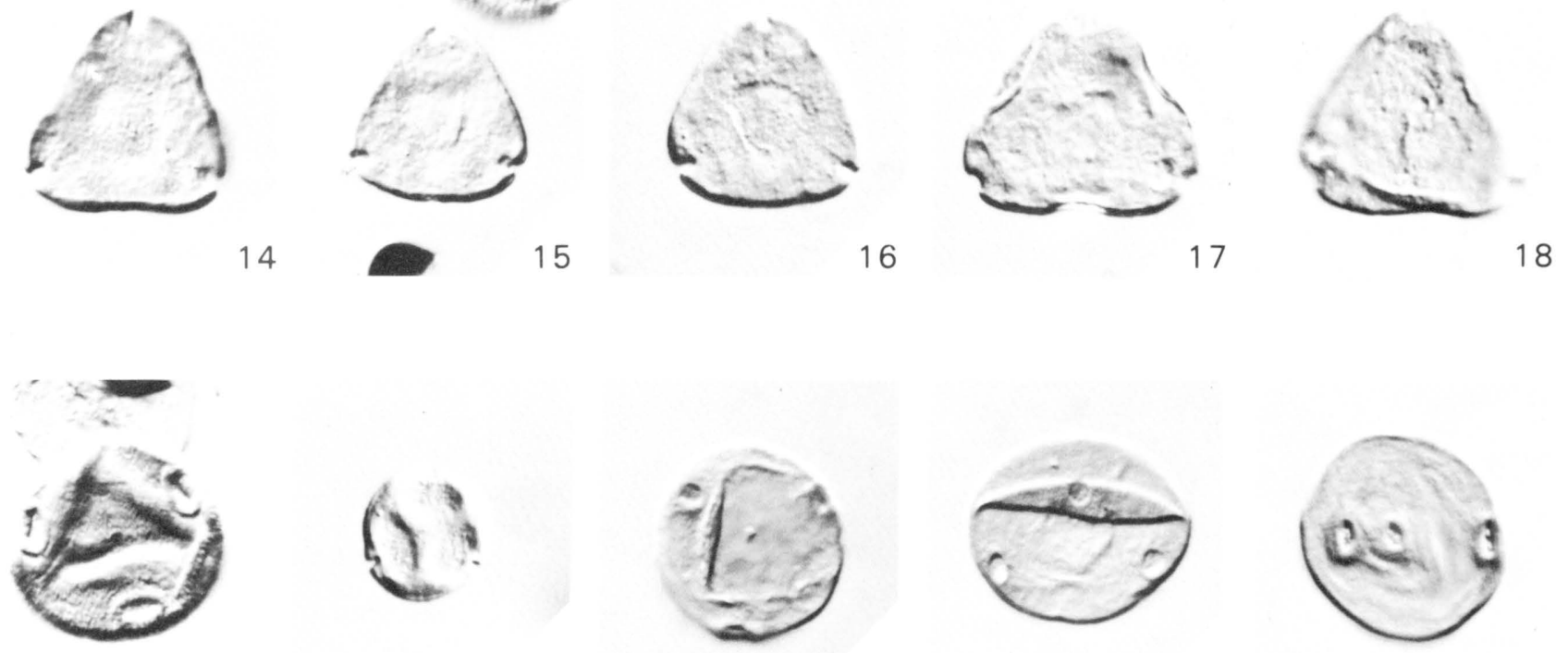

19

20

21

22

TRICOLPORATE, SYNCOLPORATE, MONOPORATE, AND TRIPORATE ANGIOSPERM POLLEN 
PLATE 9. Triporate, multiporate, and dyad angiosperm pollen

[All specimens $\times 1,000$. England Finder coordinates in brackets]

FIGURES 1, 2. Triporollenites granilabratus (Stanley) n. comb.

1. East Beaver Creek, Mont.; slide D6937-K (1) [O63/4].

2. Jacobs Coulee, Mont.; slide D6940-F (1) [N38/4].

3, 4. Triporopollenites infrequens (Stanley) Frederiksen.

3. Jacobs Coulee, Mont.; slide D6940-AA (1) [Q35/1].

4. Jacobs Coulee, Mont.; slide D6940-AA (1) [Q37/2].

5, 6. Triatriopollenites subtriangulus (Stanley) Frederiksen.

5. East Beaver Creek, Mont.; slide D6937-D (1) [N41/1].

6. Leverett Butte, Wyo.; slide D7421-D (1) [N50/2].

7, 8. Ulmipollenites krempii (Anderson) Frederiksen.

7. Triporate specimen; East Beaver Creek, Mont.; slide D6937-K (1) [P57/1].

8. Quadraporate specimen; Dry Creek, Mont.; slide D7000-B (1) [S58/O].

9, 10. Chenopodipollis spp.

9. East Beaver Creek, Mont.; slide D6937-L (1) [Q63/1].

10. South Snyder Creek, Wyo.; slide D7422-F (1) [O50/3].

11, 12. Erdtmanipollis cretaceus (Stanley) Norton. Two levels of focus on a single specimen; Lance Creek 2, Wyo.; slide D7137-I (1) [S54/3].

13-15. Penetetrapites inconspicuus Sweet.

13, 14. Two levels of focus on a single specimen; Lance Creek 1, Wyo.; slide D7100-C (1) [J68/2].

15. Dry Creek, Mont.; slide D7000-B (1) [G57/3].

16-18. Dyadonapites reticulatus Tschudy.

16, 17. Two levels of focus on a single specimen; South Snyder Creek, Wyo.; slide D7422-E (1) [R58/2].

18. Lance Creek 1, Wyo.; slide D7100-B (1) [M41/3]. 

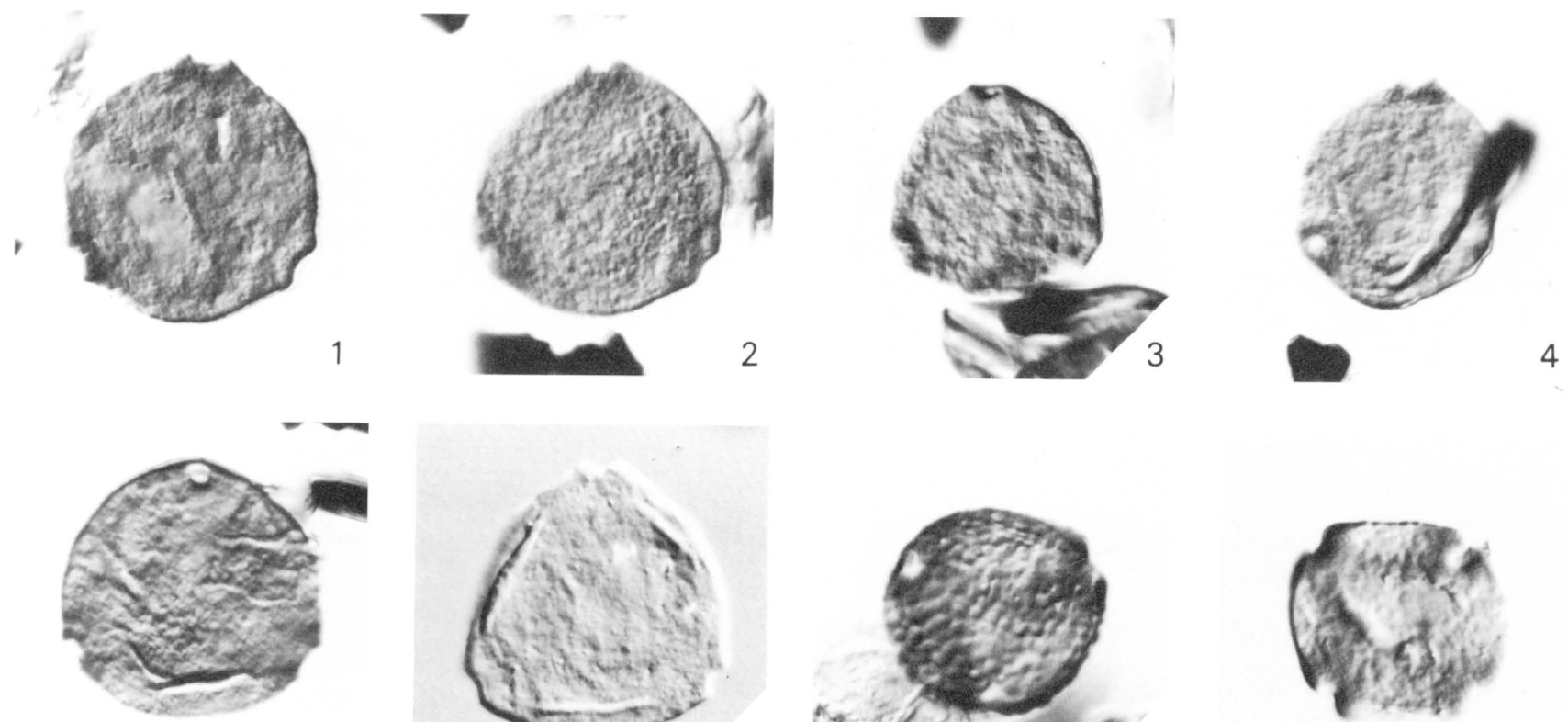

5
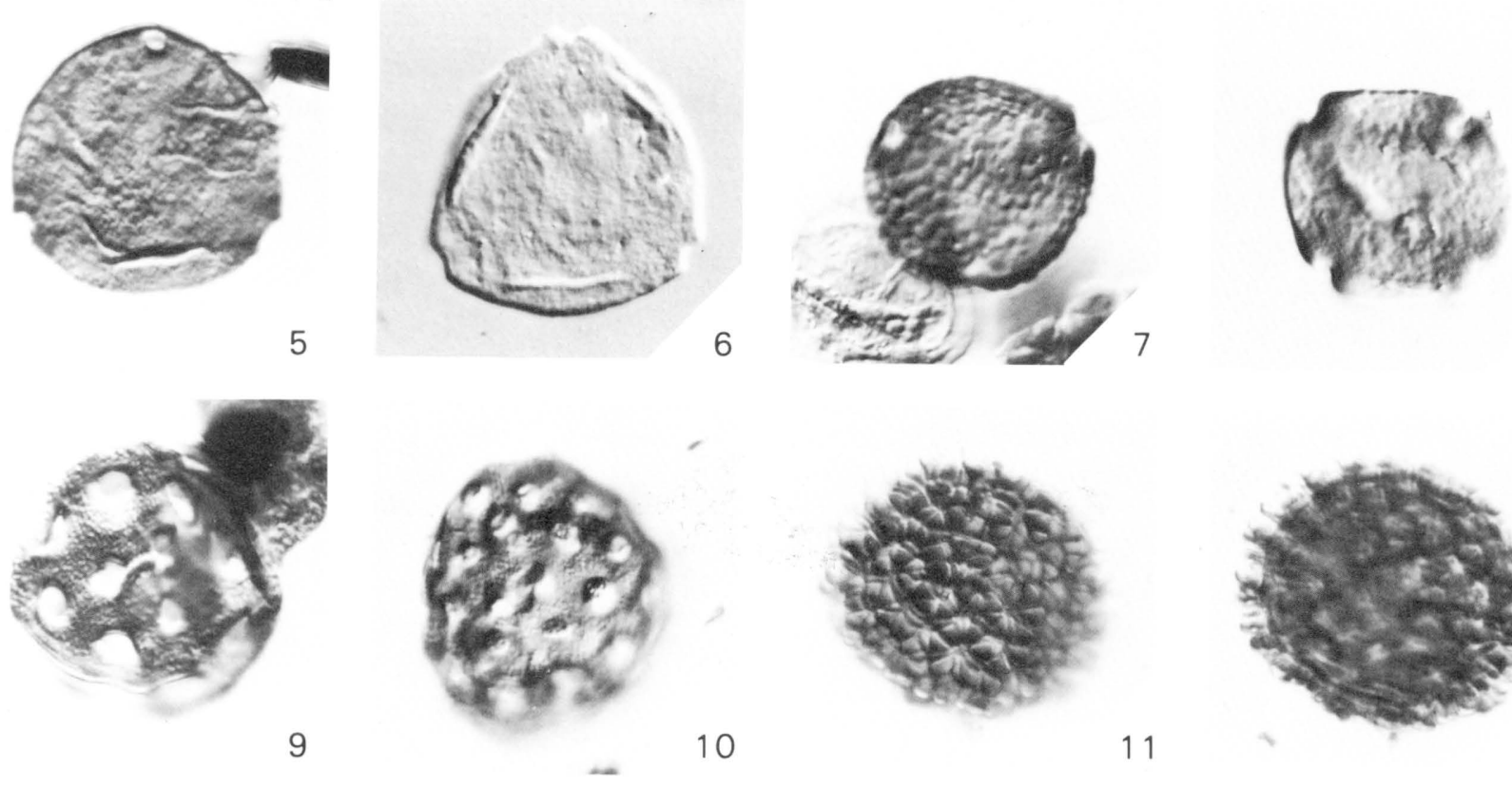

11
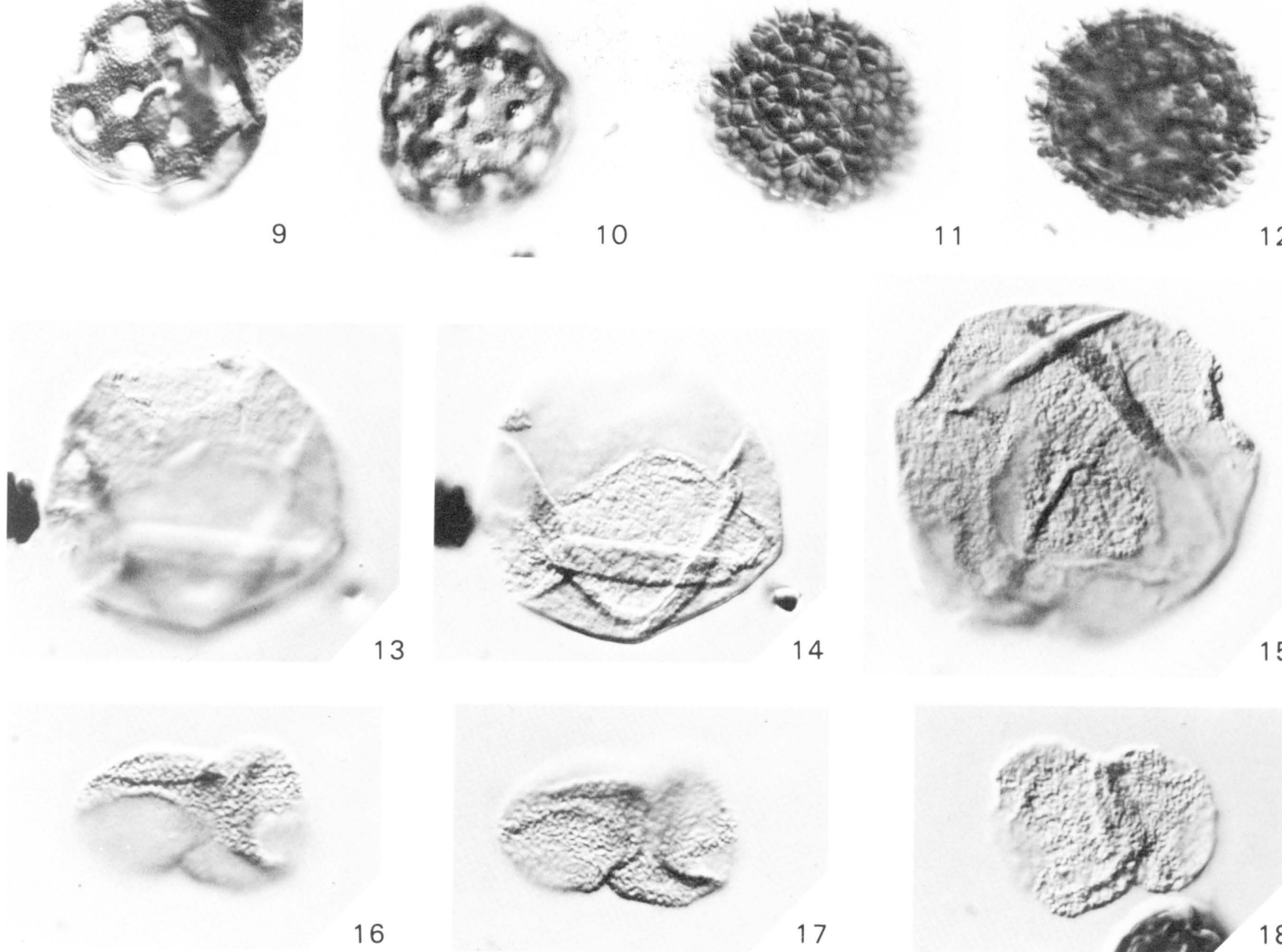

18

TRIPORATE, MULTIPORATE, AND DYAD ANGIOSPERM POLLEN 
PLATE 10. Jugate, triprojectate, and multiporate (oculate) angiosperm pollen

[All specimens $\times 1,000$. England Finder coordinates in brackets]

FIGURES 1-6. Simplicepollis rallus (Stanley) n. comb.

1-3. Three levels of focus on a single specimen; South Snyder Creek, Wyo.; slide D7422-E (1) [R59/2].

4, 5. Two levels of focus on a single specimen; Lance Creek 1, Wyo.; slide D7100-C (1) [J61/2].

6. Cow Creek, Wyo.; slide D7419 (1) [K63/1].

7. Inaperturotetradites scabratus Tschudy. Dry Creek, Mont.; slide D7000-B (1) [V51/2].

8, 9. Aquilapollenites reticulatus (Mtchedlishvili) Tschudy \& Leopold. Two levels of focus on a single specimen; South Snyder Creek, Wyo.; slide D7422-F (1) [L61/2].

10, 11. Wodehouseia spinata Stanley.

10. Dry Creek, Mont.; slide D7000-B (1) [K66/O].

11. East Beaver Creek, Mont.; slide D6937-D (1) [K36/O].

12. Wodehouseia fimbriata Stanley. Reno Creek, Mont.; slide D7411-K (1) [R40/2]. 

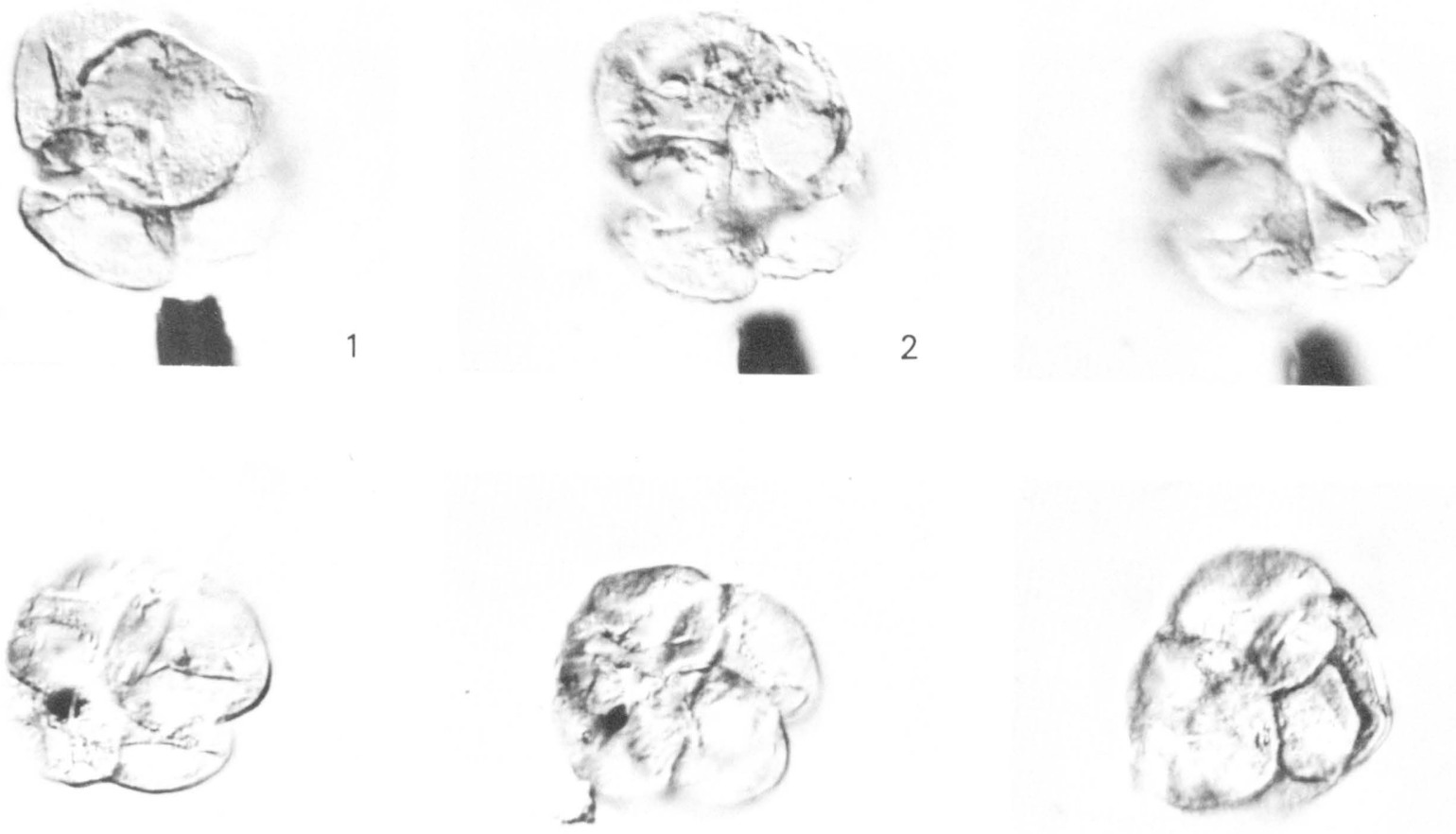

4
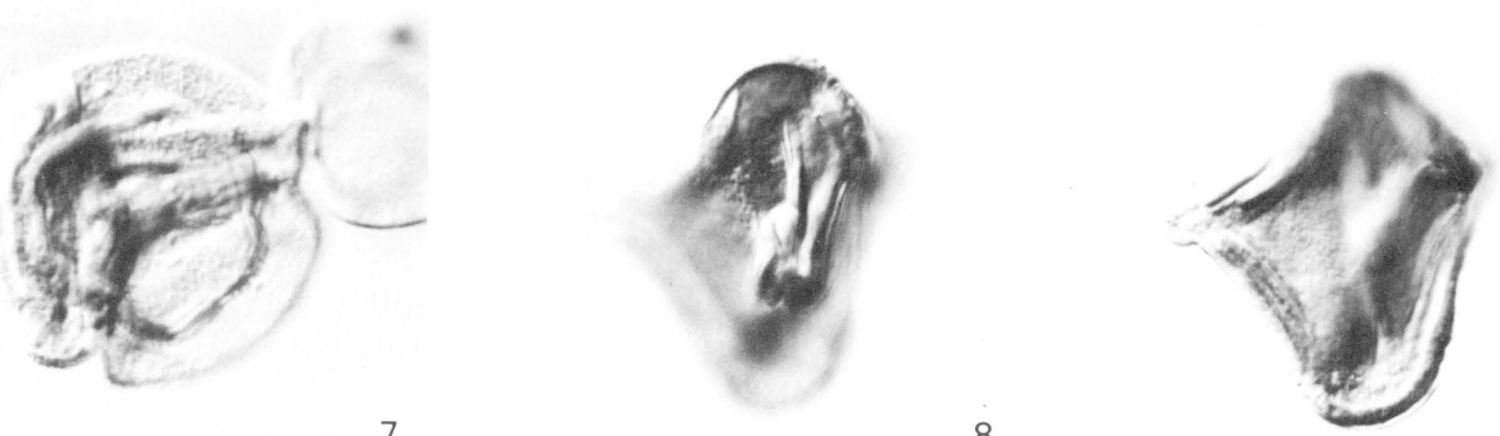

9
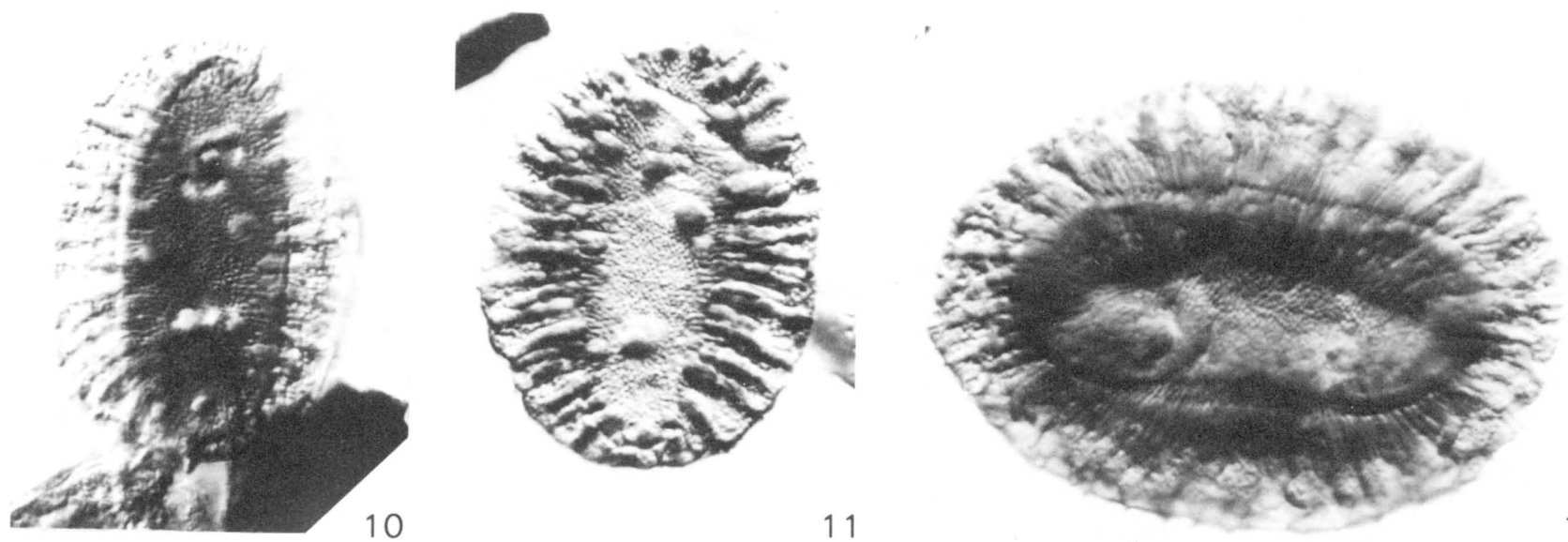

JUGATE, TRIPROJECTATE, AND MULTiporate (OCUlate) ANGIOSPERM POLLEN 


\section{SELECTED SERIES OF U.S. GEOLOGICAL SURVEY PUBLICATIONS}

\section{Periodicals}

Earthquakes \& Volcanoes (issued bimonthly).

Preliminary Determination of Epicenters (issued monthly).

\section{Technical Books and Reports}

Professional Papers are mainly comprehensive scientific reports of wide and lasting interest and importance to professional scientists and engineers. Included are reports on the results of resource studies and of topographic, hydrologic, and geologic investigations. They also.include collections of related papers addressing different aspects of a single scientific topic.

Bulletins contain significant data and interpretations that are of lasting scientific interest but are generally more limited in scope or geographic coverage than Professional Papers. They include the results of resource studies and of geologic and topographic investigations; as well as collections of short papers related to a specific topic.

Water-Supply Papers are comprehensive reports that present significant interpretive results of hydrologic investigations of wide interest to professional geologists, hydrologists, and engineers. The series covers investigations in all phases of hydrology, including hydrology, availability of water, quality of water, and use of water.

Circulars present administrative information or important scientific information of wide popular interest in a format designed for distribution at no cost to the public. Information is usually of short-term interest.

Water-Resources Investigations Reports are papers of an interpretive nature made available to the public outside the formal USGS publications series. Copies are reproduced on request unlike formal USGS publications, and they are also available for public inspection at depositories indicated in USGS catalogs.

Open-File Reports include unpublished manuscript reports, maps, and other material that are made available for public consultation at depositories. They are a nonpermanent form of publication that maybe cited in other publications as sources of information.

\section{Maps}

Geologic Quadrangle Maps are multicolor geologic maps on topographic bases in 7 1/2- or 15-minute quadrangle formats (scales mainly $1: 24,000$ or $1: 62,500$ ) showing bedrock, surficial, or engineering geology. Maps generally include brief texts; some maps include structure and columnar sections only.

Geophysical Investigations Maps are on topographic or planimetric bases at various scales, they show results of surveys using geophysical techniques, such as gravity, magnetic, seismic, or radioactivity, which reflect subsurface structures that are of economic or geologic significance. Many maps include correlations with the geology.

Miscellaneous Investigations Series Maps are on planimetric or topographic bases of regular and irregular areas at various scales; they present a wide variety of format and subject matter. The series also includes 7 1/2-minute quadrangle photogeologic maps on planimetric bases which show geology as interpreted from aerial photographs. The series also includes maps of Mars and the Moon.
Coal Investigations Maps are geologic maps on topographic or planimetric bases at various scales showing bedrock or surficial geology, stratigraphy, and structural relations in certain coal-resource areas.

Oil and Gas Investigations Charts show stratigraphic information for certain oil and gas fields and other areas having petroleum potential.

Miscellaneous Field Studies Maps are multicolor or black-andwhite maps on topographic or planimetric bases on quadrangle or irregular areas at various scales. Pre-1971 maps show bedrock geology in relation to specific mining or mineral-deposit problems; post-1971 maps are primarily black-and-white maps on various subjects such as environmental studies or wilderness mineral investigations.

Hydrologic Investigations Atlases are multicolored or black-andwhite maps on topographic or planimetric bases presenting a wide range of geohydrologic data of both regular and irregular areas; the principal scale is $1: 24,000$, and regional studies are at 1:250,000 scale or smaller.

\section{Catalogs}

Permanent catalogs, as well as some others, giving comprehensive listings of U.S. Geological Survey publications are available under the conditions indicated below from the U.S. Geological Survey, Books and Open-File Reports Sales, Box 25425, Denver, CO 80225. (See latest Price and Availability List.)

"Publications of the Geological Survey, 1879-1961" may be purchased by mail and over the counter in paperback book form and as a set microfiche.

"Publications of the Geological Survey, 1962-1970" may be purchased by mail and over the counter in paperback book form and as a set of microfiche.

"Publications of the U.S. Geological Survey, 1971-1981" may be purchased by mail and over the counter in paperback book form (two volumes, publications listing and index) and as a set of microfiche.

Supplements for 1982, 1983, 1984, 1985, 1986, and for subsequent years since the last permanent catalog may be purchased by mail and over the counter in paperback book form.

State catalogs, "List of U.S. Geological Survey Geologic and Water-Supply Reports and Maps For (State)," may be purchased by mail and over the counter in paperback booklet form only.

"Price and Availability List of U.S. Geological Survey Publications," issued annually, is available free of charge in paperback booklet form only.

Selected copies of a monthly catalog "New Publications of the U.S. Geological Survey" is available free of charge by mail or may be obtained over the counter in paperback booklet form only. Those wishing a free subscription to the monthly catalog "New Publications of the U.S. Geological Survey" should write to the U.S. Geological Survey, $582 \mathrm{Na}$ tional Center, Reston, VA 22092.

Note.-Prices of Government publications listed in older catalogs, announcements, and publications may be incorrect. Therefore, the prices charged may differ from the prices in catalogs, announcements, and publications. 


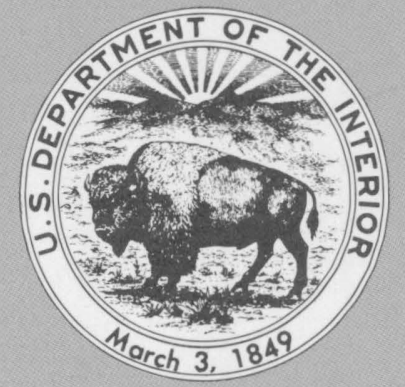

